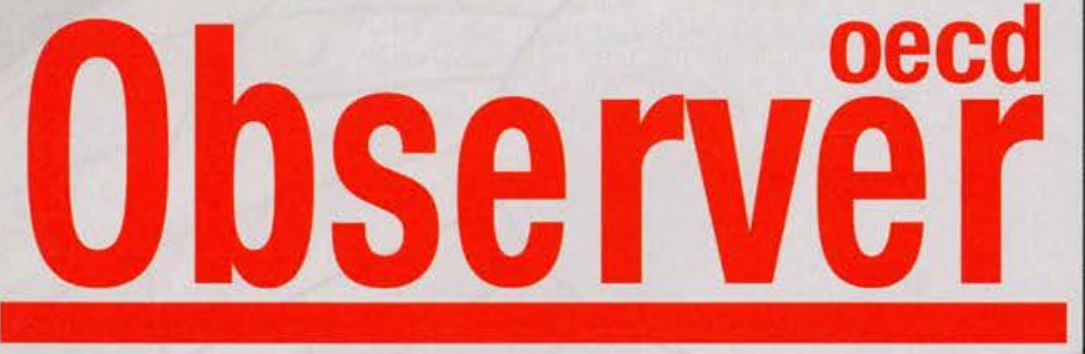

No. 243 - May 2004

www.oecdobserver.org
Fighting cancer

EU migration

Healihier boardrooms

Road risks
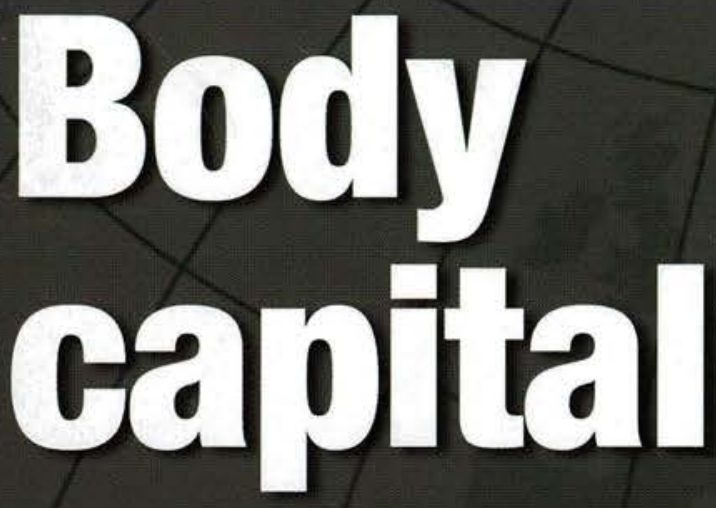

\section{Citizens}

Economies

\section{Business}

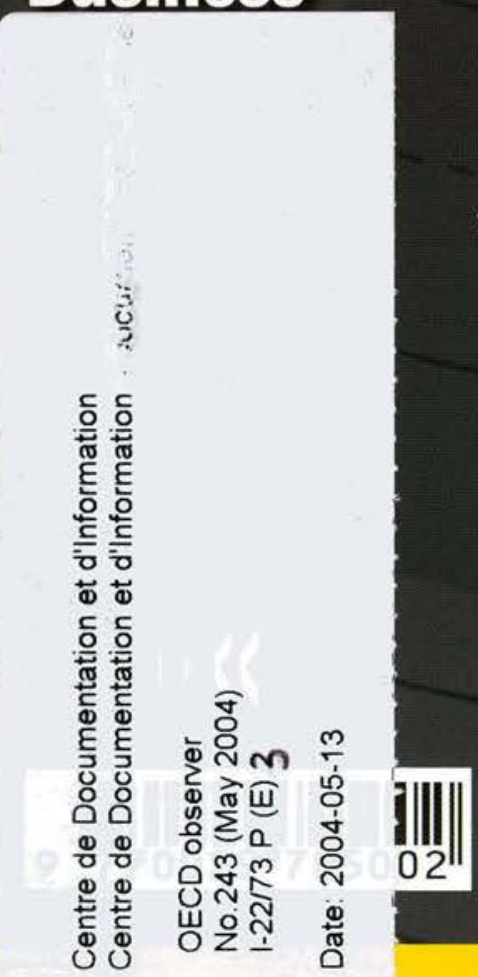

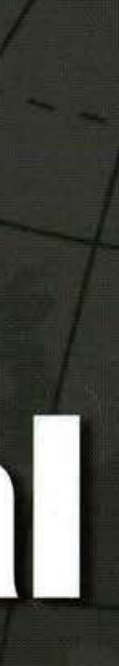
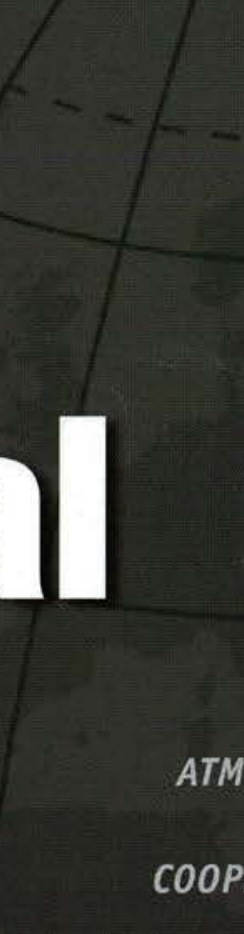

CREATIVITY

ATMOSPHERE

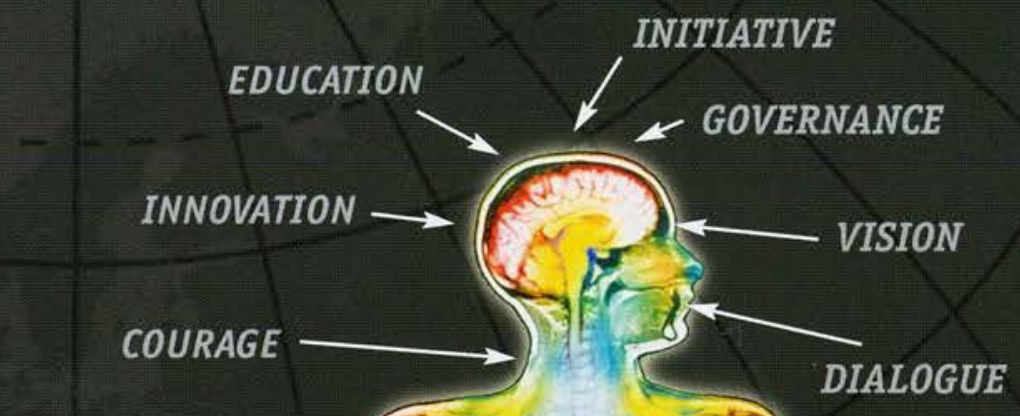

INITIATTVE

COOPERATION

SOCIAL COHESION

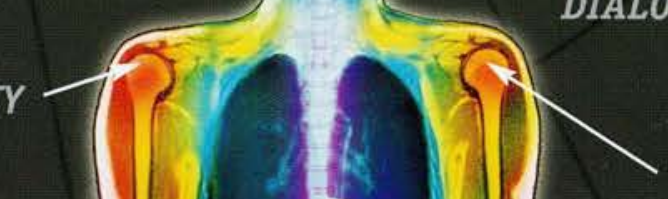

SOLIDARITY

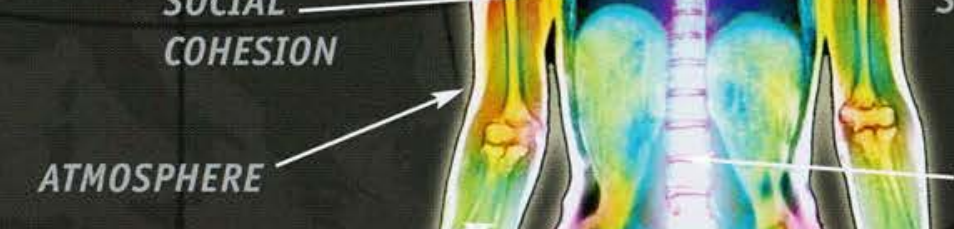

ENERGY

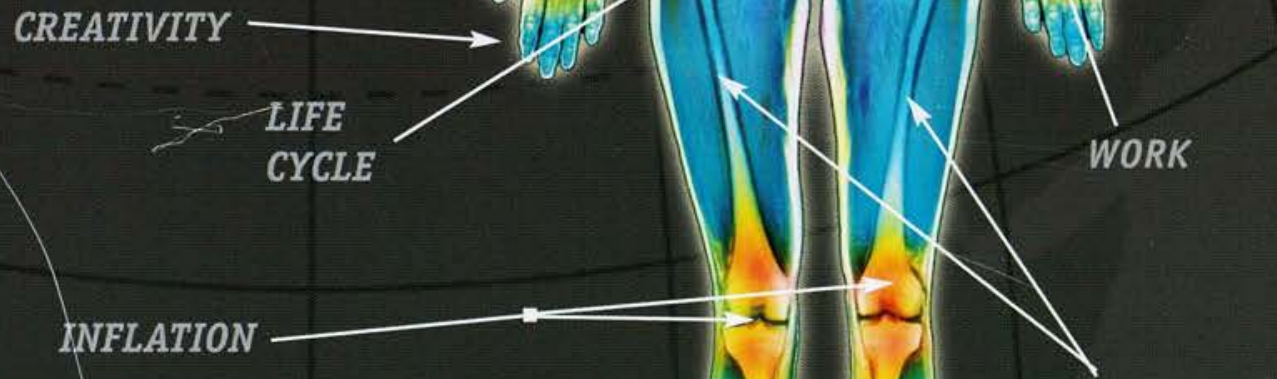

STRENGTH

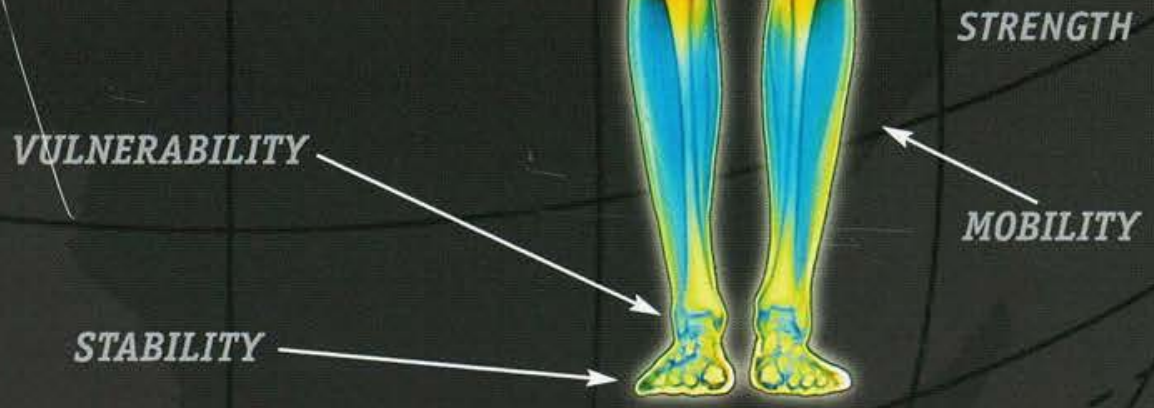

UEUU rorum 2004...,OECD Forum 2004...OECD Forum 2004... HEALTH OF NATIONS...HEALTH OF NATIONS...HEALTH OF NATIONS 

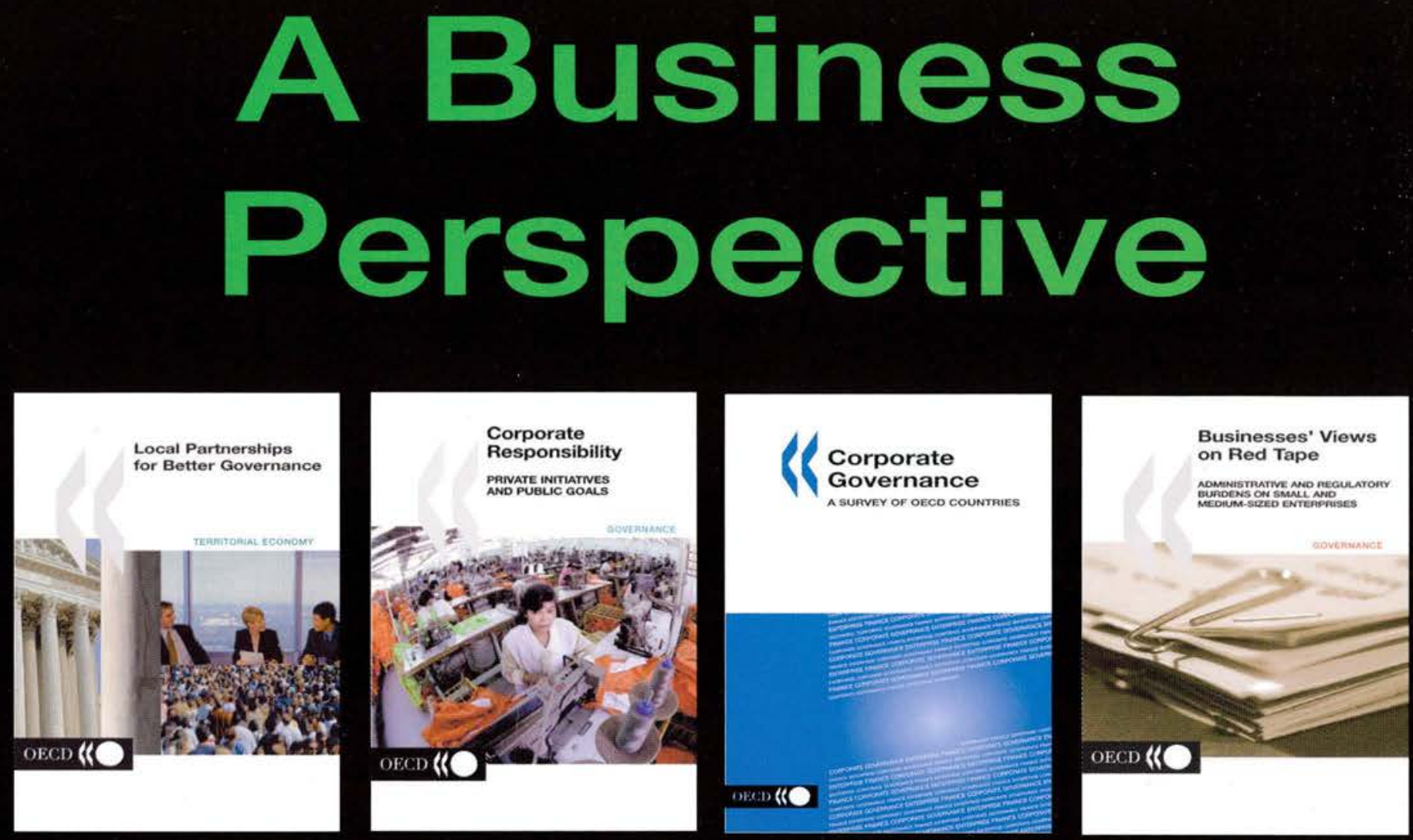

\section{JUST PUBLISHED: \\ OECD Principles of Corporate Governance: 2004}

\section{Order OECD publications at: www.oecd.org/bookshop}

To be the first to know about new OECD publications on governance, sign up for OECDDirect, our free e-mail alert service: www.oecd.org/OECDDirect 


\section{Contents}

\section{LETTERS}

2 Tax business; Female values

\section{EDITORIAL}

3 Fewer people, more heat

Donald J. Johnston

\section{LEADERS}

$4 \quad$ Health of nations

Vicente Fox

5 EU enlargement and the OECD: A new era John Rowan

\section{NEWS BRIEF}

7 Trade rises; Pollution poll; Tax havens; Growth ahead; Jobless rate holding; Tax wedges fall

\section{SOCIETY: HEALTH}

9. Health and the economy: A vital relationship

Julio Frenk

11 To our future health

Berglind Ásgeirsdóttir

14 Can new infectious diseases be stopped? Lessons from SARS and avian influenza Anarfi Asamoa-Baah

16 Living with cancer Andrew C. von Eschenbach

19 Road safety: Making roads healthy Jack Short

21 Biotech and the pharmaceutical industry: Back to the future

Marcia A. Kean

22 Frankie.org

23 Towards a healthy multilateral system Guy Ryder

24 Workers' UNion

25 False economies: A global health crisis Brett Parris

28 Migration and EU enlargement

\section{ECONOMY}

31 Why change is so difficult: Some reflections on the political economy of reform

Val Koromzay

33 French resistance

Christine Clerc

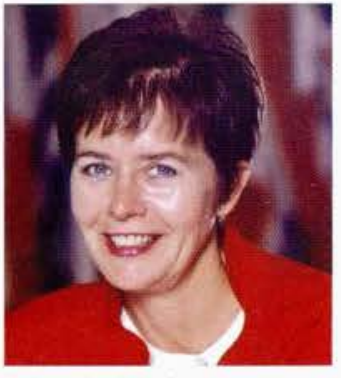

To our health, from page 9

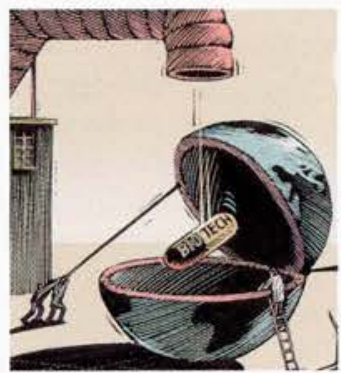

Biotech, page 21

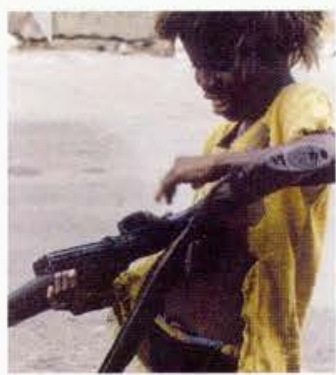

Development challenge, page 36

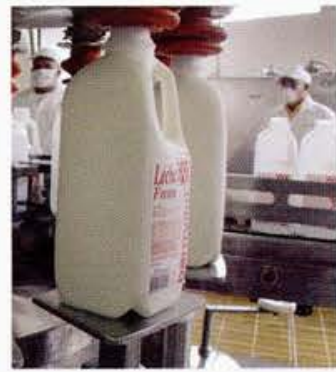

Cleaner business, page 41

Observeif www.oecdobserver.org

\section{TRADE AND DEVELOPMENT}

36 Development challenge

Richard Manning

38 Farming support: The truth behind the numbers

Stefan Tangermann

40 Know your GM crops

Peter Kearns and Masahiro Miyazako

\section{BUSINESS}

41 Corporate governance: Stronger principles for better market integrity Bill Witherell

42 Truly global

Fianna Jesover

44 Resolving international tax disputes: The role of the OECD

Jeffrey Owens

46 Small and medium enterprises: Seizing the potential

Herwig Schlögl

47 The Istanbul conference

48 Motors of innovation and development Ali Coskun

50 Renewal and innovation: A condition of the health of nations

Arnoud De Meyer

\section{OECD.ORG}

53 Learning about teaching; Global warning; Hungary, Poland visit

$54 \quad$ Calendar

\section{BOOKS}

56 Developing trust; Prevention or cure; On the right track; Government and nuclear energy; True growth

$58 \quad$ New publications

60 Order form

\section{DATABANK}

61 Healthier energy use; Nanotech is not small; Golden age; Ad strength

62 Indicators 


\section{Observeif}

www.oecdobserver.on (1) OECD 2004

2004 subscription rate:

$€ 50$ - US 550 - E31 - $¥ 5900$

ISSN 0029-7054

Tel: $+33(0) 145248200$

Fax: $+33(0) 145248210$

sales@oecd.org

Founded in 1962

The magazine of the Organisarion for Economic Co-operation and Development

OECD Publications 2 nue Andre-Pascal

75775 Paris cedex 16. France

observer@oecd.org

wwwoecd org

Published in English and French by OECD and Financial Times Business L.td, Tabernacle Court, 16-28 Tabernacle Street, London EC2A 4DD.

Tel $+44(0) 2073828000$

EDITOR-IN-CHIEF: Rory J. Clarke SENIOR EDITOR: Sue Kendall-Bilicki STATISTICS EDITOR: Eileen Cappon EDITORIAL ASSISTANTS:

Alison Benney, Rosemary Chas,

Kimberly March, Grainne Mooney

PHOTO RESEARCH: Silvia Thompson

WEB EDITION: Rory 1. Clarke

MARKETING: Toby Green

PRODUCTION DIRECTOR (FTB): Mhairi Swan

PRODUCTION (FTB)

Celine Bijleveld, Kay Burton COVER DESIGNER: Paramjit Virdee

ASSOCIATE PUBLISHER (FTB) Angus Cushley

GLOBAL. ADVERTISING MANAGER (FIB) Simon Blackmore, $+44(0) 2073828443$

\section{PRINTERS: St Ives}

Applications for permission to reproduce or translate all or parts of articles from the OECD Observer, should be addressed to:

\section{The Editor. \\ OECD Observer \\ 2 rue Andre-Pascal,}

75775 Paris, cedex 16, France

All signed articles and letters express the opinions of the authors and do not necessarily represent the opinion of the OECD.

Reprinted and translated articles should carry the credit line Reprinted from the OECD Observer', plus the date of issue. Signed articles reprinted must bear the author's name. Two voucher copies should be sent to the Editor All correspondence should be addressed to the Editor. The Organisation cannot be responsible for returning unsolicited manuscripts.

\section{Tax business}

A shade over two years ago, you wrote in this magazine (Taxation in a global environment, $O E C D$ Observer No.230 January 2002) that the time was ripe for a new social compact between governments and citizens. You wrote that the former would provide services in an efficient and cost-effective manner, while the latter would pay their taxes. Aggressive tax planning "would be considered socially unacceptable".

It's a timely reminder as ministers gather for the OECD's midterm summit later in May. They might not be aware, for example, that in April the United States General Accounting Office revealed that almost two thirds of American companies paid no tax between 1996 and 2000, despite the economy booming and profits hitting record levels.

As a result, US corporate tax receipts as a percentage of the overall tax base were at their second lowest ever in 2003, accounting for $7.4 \%$, or US\$132bn ( $\$ 71 \mathrm{bn})$ of federal receipts.

It is difficult to label this as anything other than aggressive tax planning, so much so that the actual rates of corporation tax being paid are beginning to be flagged up as a central measure of Corporate Social Responsibility (CSR). Previously, CSR was limited to mitigating the social and environmental risks incurred by high profile multinationals operating in the developing world. But in recent months, pressure groups and NGOs have started to recognise a financial dimension to CSR. The argument goes that the fair and transparent payment of tax is at the heart of the social contract between business and civil society.

The perceived injustice of corporations paying well below the effective tax rates in countries where they operate could reverberate louder and longer as a citizenship issue.

A recently established coalition, the global Tax Justice Network, believes this amounts to a hidden fault line running through the reputation of high profile multinationals. If so, it is conceivable that tax

performance could become a source of operational risk, as critics of big business begin using CSR to leverage a boardroom response while demanding governments investigate revenue shortfalls.

That is not a comforting scenario for the publicity-shy multi-billion dollar tax-planning industry. Its work may be legal, but explaining away hundreds of millions in non-tax payments through the creative deployment of transfer pricing, avoidance vehicles and tax havens should, at the very least, make for an entertaining addition to company CSR statements.

\section{Marc Lopatin}

London

marclopatin@onebox.com

\section{Female values}

You argue about integrating more women into the workforce to raise productivity, describing them in the same breath as other disadvantaged groups, including the old and the disabled. I wonder how productive all "able" groups are, women or men? Blaming low productivity on those who are not in the workforce seems misplaced in some cases and definitely ignores the economic role of women not in the workforce. How productive are all public servants, receptionists back-office secretaries, or nannies, compared with women whose non-stop business is that of looking after a home, including "productive" men? Sure, many women would like to go out to work, as long as they get the same breaks as men. But report after report shows that too often, women get a raw deal in pay and career prospects. Will that change in my lifetime? So I figure: where would you rather be, at home with your kids, teaching them, or stuck on a commuter train at five euros an hour? I work now, but when I didn't, a girl asked me if I ever thought about getting a job. I do the same work as you, better, but for no pay, I answered. She was a nanny.

Bettina Siegel

Copenhagen, Denmark

\section{Body capital}

Photo CScience Photo Library/Simon Fraser Design: FTB/OECD Observer

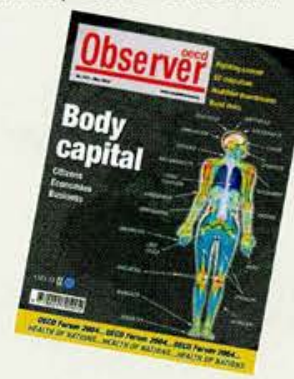

Health of Nations is not just about healthcare, but the condition of our economies, societies, businesses and our environment as well. Innovation, governance, solidarity, stability, energy, etc: these are fundamental to human well-being, and are needed to overcome our vulnerabilities and promote global development. 


\section{Fewer people, more heat}

Donald J. Johnston, Secretary-General of the OECD

$\mathrm{D}$ emography and climate change: as I read the literature and consult the experts, I am increasingly convinced that many of this century's important challenges, especially for our children and grandchildren, will flow from these two phenomena. Let me sketch some scenarios and questions with respect to each.

First, demography. Populations in the developed world are already ageing. Longer life expectancy is a great achievement. But coupled with declining birth rates, we are facing serious economic and social consequences - and soon, if current trends persist, fewer and fewer people of working age will have to support more and more retirees. The cost of pensions and healthcare, together with rising public debt, could very well place an intolerable burden upon public finances and on future workers.

Will policies be identified to arrest this demographic decline, or to increase the productivity of a smaller working population? Or will we revise social contracts in order to reduce pensions, healthcare or other social security benefits? Can we find ways to provide benefits more efficiently?

Alternatively, will $O E C D$ countries supplement their populations by attracting large numbers of migrants from the developing world? Are our societies ready to receive and integrate waves of new minorities with different cultures, religions and social values? It would be nice to think so. But even such a policy would likely founder because birth rates in many countries that send migrants are plummeting.

Perhaps our governments will respond by pushing the retirement age to 70 or 75 , or higher. Perhaps they will increase the number of hours worked - from lows such as the 1,500 hours per year worked today in Germany, to higher numbers such as the 2,400 hours in Korea.

These are difficult questions facing the developed world today. In a slightly longer timeframe they will beset developing countries, especially China which has followed a one-child policy! I am worried. Will our politicians be able to deliver the answers?

About a decade ago, conventional wisdom held that the earth's population would reach an unsustainable 12 billion people by the year 2050. We often referred to the "population time bomb" and the challenge of feeding this burgeoning population in the developing world. The reality is that the bomb already exploded as the world population increased from 1.6 billion at the end of the 19 th century to over 6 billion at the end of the 20th.

The Malthusian nightmare has receded, at least for now. But humans are exerting enormous pressure on the global environment and this brings me to the second global phenomenon which will drive policy agendas during this century: climate change.
There now seems to be indisputable evidence that global warming is upon us and accelerating. The extent to which this warming is the result of human activity remains moot, although the strong coincidence of rising temperatures and rising $\mathrm{CO}_{2}$ emissions should give pause to even the most sceptical observers. The real question about climate change is "at what rate": slow, rapid or abrupt?

The nightmare scenario is the abrupt climate change that would ensue if global temperatures passed a threshold that would induce the equivalent of climatic chaos. An analogy is a canoe which gradually tips as it fills with water - until it capsizes. This is a terrifying prospect and some argue that it may be only a decade away.

Fortunately, the more likely scenario is that climate change will continue at a pace which will permit us to adapt. It is for this reason that I have encouraged $O E C D$ members to address two issues in our environmental work: first, how to slow down climate change through the reduction of greenhouse emissions, including through the implementation of the Kyoto Protocol, and the wider use of nongreenhouse gas emitting technologies; and, second, to identify areas where adaptation and preparedness are clearly necessary.

Adaptation is the relatively new issue. Evidence is mounting that extreme weather conditions, such as the heat wave which brought death to many elderly people in Europe last summer, will be more frequent. Are we now in a position to deal with such heat waves? Can our infrastructure, such as for power provision, withstand long periods of severe heat or deep freeze? Have we identified communities at risk from flash floods? Are we ready to fight the tropical diseases that will invade our warming climates? In agriculture, can we change crops as quickly as the climate evolves and can we cope with reduced rainfalls in some areas and dramatically increased precipitation elsewhere? If sea walls cannot protect low lands, are we ready to receive "environmental refugees"? Are we ready for the day that the Gulf Stream stops?

Many questions, yet they all point to just one: are we getting ready for inevitable climate change? Whether the problems are about demographic change or climate change, thinking about them - in laboratories or universities - is not enough. We need options for public policy that can be implemented in our capitals. Obviously, these are areas where the interdisciplinary strength of the OECD, complemented by direct access to decisionmakers, should be brought to bear, and as quickly as possible.

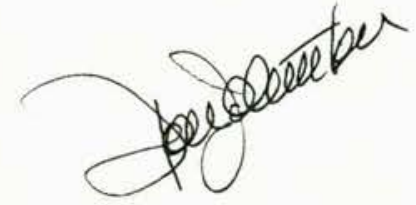

Observer No. 243 May 2004 


\title{
Health of nations
}

\author{
Vicente Fox, President of Mexico*
}

$\mathrm{M}$ exico currently has a broad and dynamic international presence. The process of change in the global economic system has increased financial and commercial ties between countries, leading to growing interdependence. Mexico's economic development nowadays depends largely on the income generated by international trade, foreign investment and tourism, which in turn depend upon the state of the world economy.

International trade is one of the main engines of economic growth in Mexico. One third of our national products is made up of exports, and a significant proportion of highly paid, high productivity jobs with good working conditions are directly and indirectly linked to sales abroad. Indeed, Mexico has been the eighth largest exporter in the world for several years.

We have engaged in a series of negotiations of regional and bilateral trade agreements in the past ten years because of the potential for development that they offer. We now have 11 bilateral and regional trade agreements with 42 countries in three continents; and we have just concluded negotiations for another one, with Japan.

Positioning Mexico in the global economy is not an end in itself, but a means with which to promote the sustained socioeconomic development of our country.

Trade and investment go hand in hand. Foreign direct investment (FDI) has grown significantly in recent years: from an average of about US $\$ 3.5$ billion per year at the beginning of the 1990s to an average of $\$ 12$ billion per annum. This inflow of foreign resources has been attracted by the prospect of healthy profits, a high-quality labour force and a stable macroeconomic climate. In fact, Mexico ranked as the world's third largest recipient of FDI in 2003, and first in Latin America.

Furthermore, Mexico has actively promoted multilateral co-operation. In March 2002, we hosted the International Conference on Financing for Development where trade and investment, together with official development assistance, were core issues. We have been able to combine our commitments under bilateral and regional agreements with the principles of multilateralism. Open regionalism has been one of the key principles that Mexico follows and practises in all our trade negotiations.

Indeed, at the Fifth World Trade Organization (WTO) Ministerial that we hosted in Cancún in 2003, Mexico played a lead role in bridging differences among WTO members in several key issues.
We will continue to work towards the completion of the Doha Development Agenda.

Our position is simple: the success of the Doha depends upon the compromise and commitment of all WTO members. Nor will there be a long lasting solution to international trade practices outside the WTO. Bilateralism is not a substitute for multilateralism, even if it complements it. We are at a crossroads in multilateral trade negotiations. Our nations, our people, are urging us to take the proper steps in the right direction.

Mexico's development agenda for the 21st century also comprises the new challenges posed by healthcare. As recently as in April, Mexico hosted an International Conference on Innovation to Health Financing. Health, as well as education, human rights protection, environmental sustainability and poverty alleviation, are the key priorities of our government.

The health of our citizens is not only an ethical responsibility, but also a central component for the development of human capital, to increase productivity and economic growth. It has a strategic dimension in terms of social equity as well.

Less than two years ago, Mexico passed amendments to the law on public health which created a health Social Protection System. Its key element is a new health insurance programme for our people. Before this reform, over $57 \%$ of Mexicans lay outside the formal health system and had to finance their own health needs. This was especially harsh on the poor.

With the new social protection system, it is expected that by 2006, five million Mexican families will benefit from the programme. By then, all citizens will have universal access to the system. The SPS is financed mostly by federal fiscal resources, as well as by the states and individuals. By halting the vicious circle of poverty-diseases-poverty, the Mexican government is fulfilling its responsibility of financial protection for the health of its citizens.

Healthy nations depend on healthy citizens. Governments should make every effort to reach this goal. The 2004 OECD Forum is an invaluable occasion to discuss some of the challenges. Such dialogue is important so we can improve the health of our nations and the health of the world.

* Mexico is chairing the 2004 OECD Ministerial Council on 13-14 May and will be actively participating in the OECD Forum on 12-13 May. 


\section{EU enlargement and the OECD}

\section{A new era}

John Rowan, Ambassador of Ireland to the OECD

$\mathrm{T}$ he formal accession to the European Union of 10 new member states on 1 May 2004 is a defining moment in the history of Europe. The Irish Presidency was honoured to welcome the accession states as full members of the Union and to celebrate together this great event with a "Day of Welcomes".

Enlargement on this scale, from 15 to 25 members, is unprecedented in the Union's history. (The largest previous single wave of new entrants, not counting the six founding members, was three, with Austria, Finland and Sweden joining in 1995, and Denmark, Ireland and the UK in 1973.) While it presents clear opportunities, it also presents challenges. We are working to facilitate a smooth transition, integrating the new member states fully and effectively into the structures of the Union. At the same time, there is a focus on extending and adapting existing programmes in all policy areas to the new member states. The necessary steps are being taken to integrate them as rapidly as possible into the Lisbon strategy for economic, social and environmental reform, the Schengen Acquis on free movement of people and the economic policy co-ordination process.

No organisation understands better the problem of helping member countries with greatly different standards of living to work together than the OECD. Assisting member countries to learn from shared experience is at the heart of the OECD's activities. The peer pressure, the quality and extent of the analyses and reviews, have all contributed to improvements in economic performance and the strengthening of social cohesion. Indeed, those four new member states of the EU which are already members of the OECD the Czech Republic, Hungary, Poland and the Slovak Republic - have acknowledged the invaluable role the organisation has played in their preparations for EU accession, through both dedicated programmes and their participation in the wide-ranging activities of the OECD.

However, no EU members, old or new, have any illusions that all the hard work has been done. Delivering security and prosperity, continuing reform efforts, enhancing education systems and creating a cleaner environment are all daunting, ongoing policy goals. Globalisation presents new opportunities which can assist us in reaching those goals, but these opportunities can only be fully realised if the international community has the will to work together to establish accepted codes of behaviour. The relevance of the OECD in this context is widely recognised, and the organisation can make a real difference.

It has been gratifying to hear lreland cited as an example of how to achieve economic and social progress. Obviously, the skills and

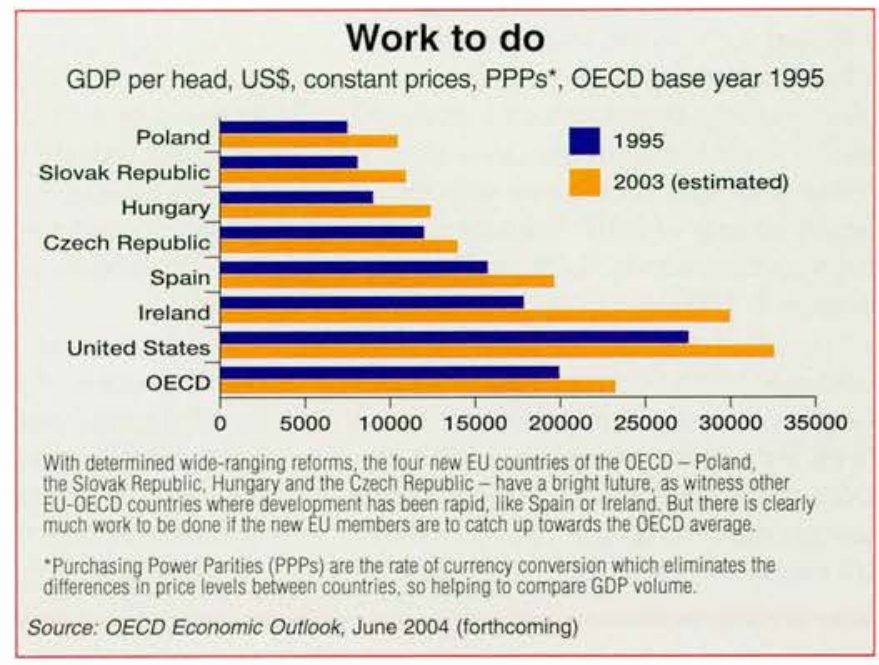

adaptability of our greatest asset, our people, contributed hugely to the remarkable development of recent years. However, membership of the $\mathrm{EU}$ and the OECD was critical to our success. Through the $\mathrm{OECD}$, Ireland, like all member countries large and small, has been able to identify areas where reform would make a real difference to performance, in labour markets, entrepreneurship, governance, public/private partnerships, and so on. The part played by the $O E C D$ in the evolution of the Irish education system, for instance, was an indispensable element of our growth.

EU expansion is a reminder that international organisations have to adapt in a world of rapid change. The OECD is demonstrating that it both recognises this and will act upon it, thanks in part to landmark reports by OECD Ambassadors Jorma Julin of Finland and Seiichiro Noboru of Japan on the critical areas of reform, enlargement and outreach to non-OECD countries. These studies will assist ministers at their Council meeting in May to take decisions on the future direction of the OECD based on a very clear common vision of where we are and where we must go.

In celebrating EU enlargement at this time, we also stand on the threshold of a new era in the evolution of the OECD. There is no lack of opportunities and challenges for us all.

\section{References}

- For more on the Lisbon Strategy and Schengen, see http://europa.eu.int/comm

- For more on the Irish Presidency of the EU, see www.eu2004.ie

- Julin, J. (2003), "The OECD: Securing the Future", in OECD Observer, No. 240/241, December, available online at http://www.oecdobserver.org/oecdfuture2003julin 


\section{Trade rises}

Total merchandise import volumes of the G7 countries were up by a seasonally adjusted $3.5 \%$ in the final quarter of 2003 compared with the previous quarter, while export volumes increased by $1.9 \%$, according to our latest statistics released in April. Compared with the fourth quarter of 2002, imports rose by $5.1 \%$ and exports by $3.7 \%$ in the fourth quarter of 2003.

Compared with the third quarter of 2003, Germany's trade volumes were up by $5.4 \%$ for imports, but exports fell $0.2 \%$. On a year-to-year basis, Germany's trade volume growth was the highest of the G7 countries, with $10.6 \%$ for imports, but only slightly above the G7 average for exports

In the United States, import volumes increased by $4.3 \%$ in the fourth quarter compared with the third, while export volumes were up by $4.9 \%$. Compared with the fourth quarter of 2002, exports increased by $7.2 \%$, while imports climbed $5.4 \%$.

The volume growth of Japanese exports was the highest of the G7 with $5.1 \%$ in the fourth quarter, compared with the third quarter, while import volumes grew $2.0 \%$. On a year-to-year basis, Japan's export volume growth in the fourth quarter was $7.1 \%$, while import growth was $7.2 \%$.
Trade growth

$\%$ change, seasonally adjusted

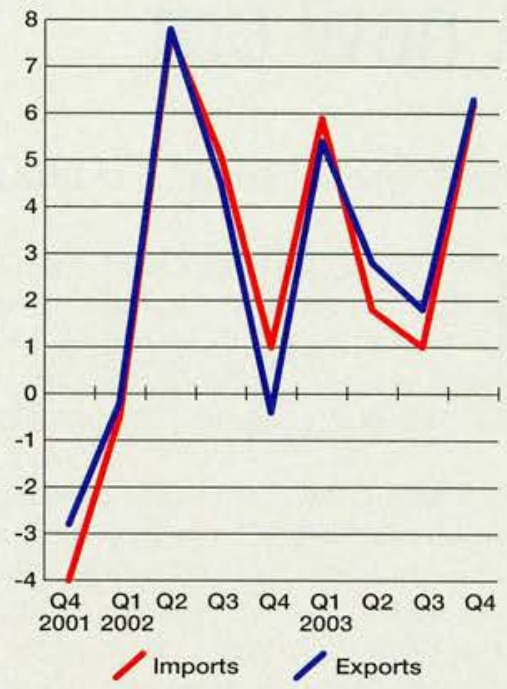

Source: $\mathrm{OECD}$

\section{Pollution most urgent, says poll}

Pollution is the most urgent environmental policy problem on the agenda, according to OECD Observer readers. Asked to choose between four broad categories - pollution, climate change, urban congestion or sprawl and deforestation/biodiversity - the results of the Observer's online opinion poll show that $42 \%$ of respondents overall believe pollution should be the top issue on the environmental agenda. Interestingly, a remarkable $52 \%$ of respondents to the poll on the French edition (www.observateurocde.org) highlighted pollution as the most prominent issue, compared to $33 \%$ for the English edition.

\section{Climate change was the main} environmental problem for $24 \%$ of the voters overall. Some $28 \%$ of respondents to the English version chose climate change, compared with $19 \%$ for the French edition. A further $22 \%$ overall thought the threat to biodiversity and deforestation should be addressed first, while $12 \%$ of the overall vote went to urban congestion or sprawl.

The OECD Observer's opinion poll, which was purely indicative and not scientific in its sample, ran from February to April to coincide with the OECD Environment Ministers meeting on 20-21 April. A total of 1,758 votes were cast, of which 952 were for the English edition and 806 were for the French version.

\section{Tax havens progress}

Major progress has been made in the effort to eliminate harmful tax practices in the OECD economies. More than 30 of the preferential tax regimes identified in 2000 as potentially harmful have been modified or abolished.

According to the 2004 progress report on the OECD's Project on Harmful Tax

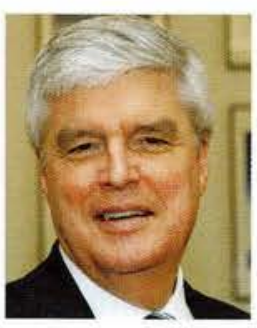

Mr McCloskey

\section{any potentially}

harmful features have been removed, and 13 have been found on further examination not to be actually harmful. Two regimes, thoset of Switzerland and
Luxembourg, are to be the subject of further discussion later this year.

Bill McCloskey, chairman of the OECD's Committee on Fiscal Affairs which is leading the drive against harmful tax practices, hailed these positive results. "The work has resulted in real change," he said in a statement. "OECD countries have shown that they will take action to ensure that tax competition is fair."

The full report is available at: www.oecd.org/ctp/htp 


\section{Growth ahead}

The OECD area as a whole seems set for further growth, according to the latest composite leading indicators published in April. Forecasts from the Economic Outlook time of writing. However, figures for the

according to leading indicators for the $O E C D$ area, which increased by 0.2 point in February to 123.2. The six-month rate of change indicated a downturn for the second month in a row after almost a year on the rise.

In the US, leading indicators were up by 0.2 point as well, with the six-month rate strongly increasing for the previous nine consecutive months. Similarly, leading indicators for the Euro area rose 0.3 point, while the six-month rate of change fell for the third consecutive month. Germany's leading indicators increased by 0.1 point, with the six-month rate of change down for the second month in a row.

Japan continued to show signs of recovery. Leading indicators there were unchanged and have been relatively stable since July 2003. due in May were under embargo at the US and the Euro area show signs of slightly weakening economic performance, of change down for the second month after

The OECD's leading statistics cover a wide range of key short-term economic indicators and are designed to provide early signals of turning points (peaks and troughs) in economic activity. More information on OECD leading indicators can be found at www.oecd.org/statistics.

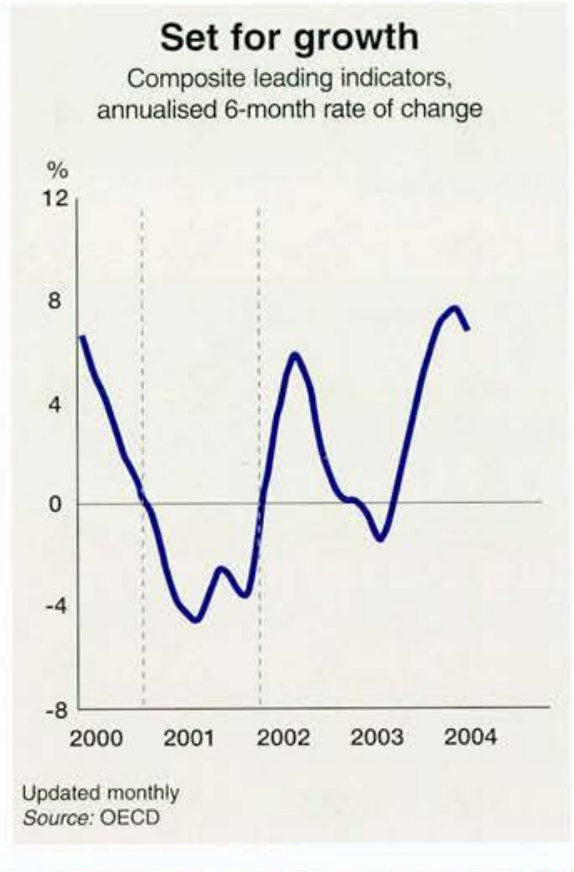

\section{Jobless rate holding}

Unemployment seems to be holding steady in the OECD area, albeit still above optimal levels. At $6.9 \%$, the unemployment rate in February 2004 remained unchanged for the third month in a row, though 0.1 percentage point lower than a year earlier

For the Euro area as a whole, unemployment remained at a steady, but high, $8.8 \%$, down 0.1 percentage point from the same period in 2003. While France posted a 0.2 percentage point rise to $9.4 \%$ and Germany a 0.1 percentage point increase to $9.3 \%$, the UK and Italy showed declines in their jobless rates, down 0.1 percentage point to $4.8 \%$ and 0.4 percentage point to $8.5 \%$, respectively (the latest Italy figures are, however, for January 2004).

Unemployment in the US rose 0.1 percentage point in March 2004 to $5.7 \%$ from the previous month, but as with the OECD average, declined 0.1 percentage point from the same period a year earlier. Canada's jobless rate similarly posted a 0.1 percentage point drop year on year, to $7.4 \%$ in February 2004. A larger decline was seen in Japan, where unemployment fell 0.2 percentage point year on year to $5.0 \%$.
Tax wedges fall

Tax wedges on labour - the difference between what employers pay out in wages and social security charges and what employees take home after tax and social security deductions - are falling in many OECD countries, helping to reduce a major obstacle to job creation and people's willingness to work. According to the forthcoming OECD publication, Taxing Wages, the tax wedge for a typical married production worker with two children, measured as a percentage of the overall cost to the employer, has declined over the last seven years by about one and a half percentage points across OECD countries.

Ireland saw the biggest fall in the tax wedge from 1996 to 2003, with a reduction of 18.3 percentage points, followed by Hungary at 9.9 percentage points, the US at 8.3 percentage points, Italy at 8.2 percentage points and the UK at 7 percentage points. However, in a number of countries the tax wedge increased over the period, with Iceland seeing the biggest increase, at 9.5 percentage points, followed by the Slovak Republic at 7.1 percentage points and Turkey at 3.8 percentage points.

The rates of personal income taxes, social security contributions and cash benefits in OECD countries vary widely, depending on a worker's income, family circumstances and country of residence. But Taxing Wages also confirms some significant features common to taxation systems in most OECD countries. Most OECD countries continue, for example, to offer significant benefits to married couples with children compared to single earners.

Further information from Taxing Wages at: www.oecd.org/ctp/taxingwages 


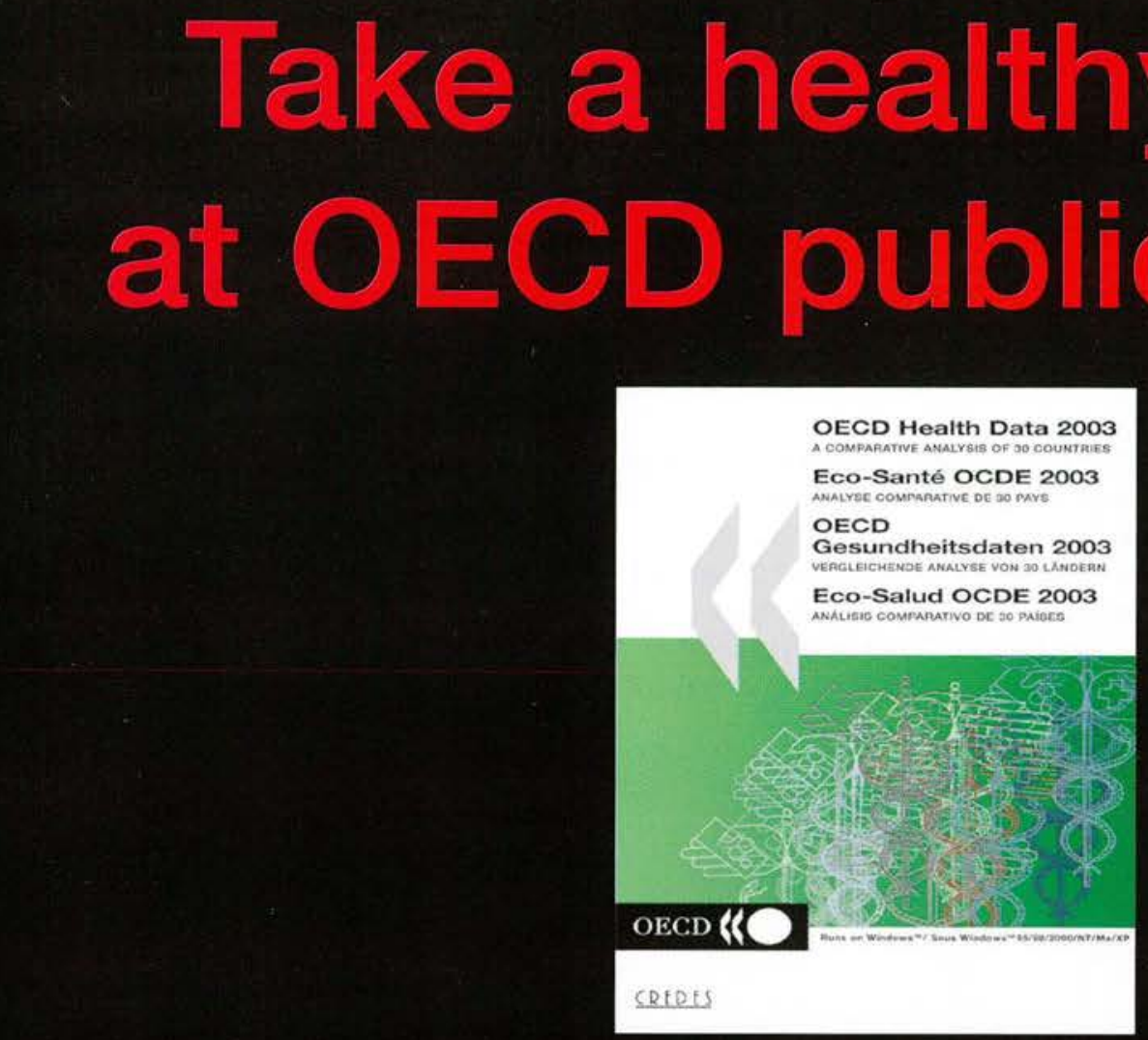

\section{FORTHCOMING SPRING 2004! OECD Health Data 2004:}

A Comparative Analysis of $\mathbf{3 0}$ Countries: 2004 Edition

The OECD Health Project Towards high-Performing Health Systems Private Health Insurance in OECD Counties: The OECD Health Project

The OECD Health Project Health Technologies and Decision Making

\section{Order OECD publications on health at www.oecd.org/bookshop}

To be the first to know about

$$
\text { new OECD }
$$

publications on health, sign up for OECDDirect, our free e-mail alert service: 


\section{Health and the economy A vital relationship}

Julio Frenk, Mexican Minister of Health and Chair of the 2004 meeting of OECD Health Ministers

Healthcare performance is strongly dependent on the economy, but also on the health systems themselves. This link should not be underestimated.

$\mathrm{I}$ nvestment in health is not only a desirable, but also an essential priority for 1 most societies. However, our health systems face tough and complex challenges, in part derived from new pressures, such as ageing populations, growing prevalence of chronic illnesses, and intensive use of expensive yet vital health technologies. Moreover, we must deal with higher expectations of citizens and resolve persistent inequities in access and in health conditions among different groups. Little wonder that the issue of how to ensure the financial sustainability of health systems, while making a positive contribution to macroeconomic performance, has moved to the top of the policy agenda across the OECD area. Much of the work undertaken in the OECD Health Project has aimed at providing policymakers with the evidence they need to promote more value for money in the health sector, while ensuring universal access, equity and raising quality of care. We have learned a lot, though there is more to discover.
A basic message has emerged: investments in health and the design of health financing policies should be addressed in terms of the interaction between health and the economy. Just as growth, income, investment and employment are a function of the performance and quality of the economic system, its regulatory frameworks, trade policies, social capital and labour markets, etc, so health conditions (mortality,

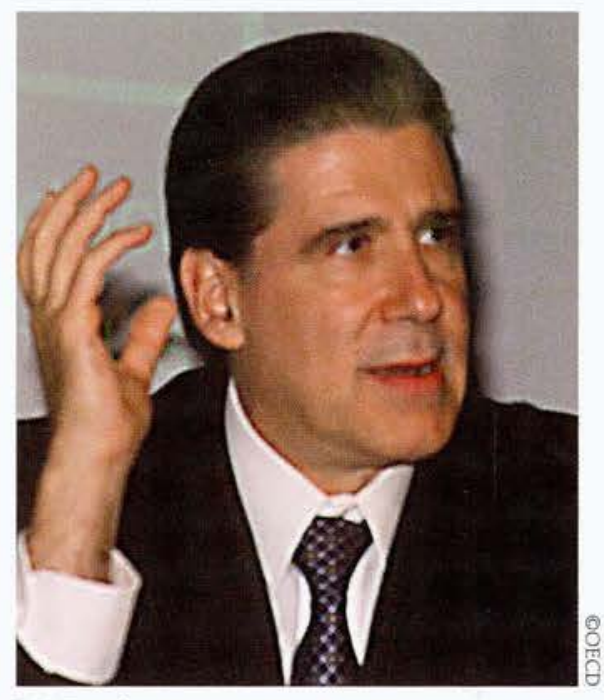

Mr Frenk

countries have healthier populations for a start. And it is a basic truth that poverty, mainly through infant malnourishment and mortality, adversely affects life expectancy. National income has a direct effect on the development of health systems, through insurance coverage and public spending, for instance. As demonstrated in 1997 by the WHO Commission on Macroeconomics and Health for a panel of 167 countries, while

\section{Health financing, through out-of-pocket expenditures, is inequitable and can expose whole populations to huge cost burdens.}

morbidity, disability) depend not just on standards of living, but on the actual performance of health systems themselves. Let us go over some of these interactions.

Health performance and economic performance are interlinked. Wealthier health expenditures are determined mainly by national income, they increase faster than income.

Another well-known relationship is an institutional one. Take the case of tobacco use. Efficient fiscal systems in the OECD 


\section{Health}

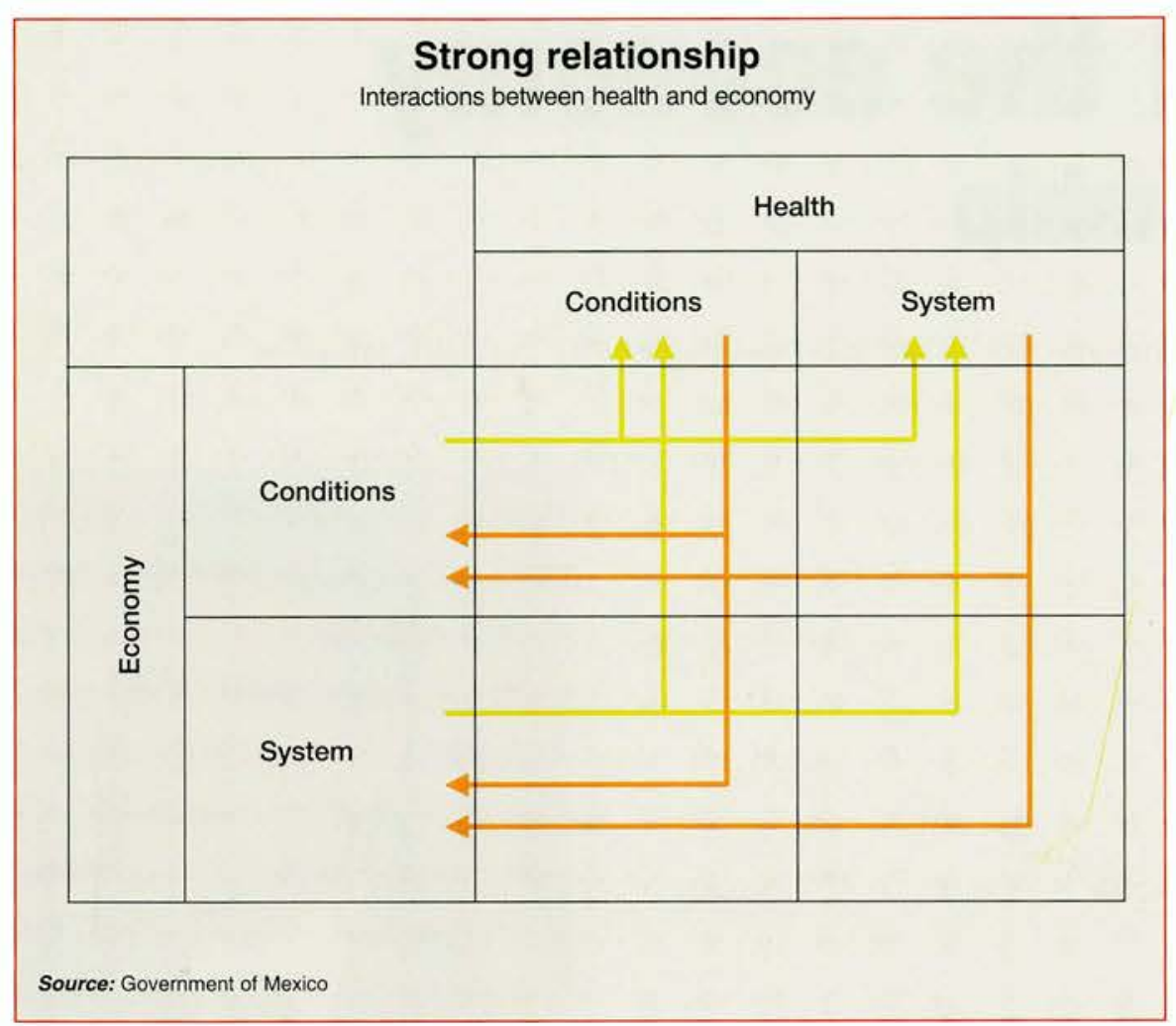

have meant that increases in taxes on tobacco could reinforce other public health policies like rule-based restrictions on smoking in public places. Some countries have gone very far in this respect, with Ireland actually banning smoking in its famous pubs! Such courageous initiatives cannot succeed without institutional backing, whether legalistic or otherwise.

Another example of how institutional arrangements can help is through universal provision of insurance coverage, which a larger fiscal base and a small informal sector help to attain. Globalisation in general, and trade liberalisation in particular, also affect healthcare, via constrained pricing and trade policies of pharmaceuticals, and the need for enhanced health surveillance across borders and populations.

The effects of health on development are clear. Countries with weak health and education conditions find it harder to achieve sustained growth. Indeed, economic evidence confirms that a $10 \%$ improvement in life expectancy at birth is associated with a rise in economic growth of some 0.3-0.4 percentage points a year.

Disease hinders institutional performance too. Lower life expectancy discourages adult training and damages productivity. Similarly, the emergence of deadly communicable diseases has become an obstacle for the development of sectors like the tourism industry, on which so many countries rely.

Policy choices cannot be taken lightly. Health financing, through out-of-pocket expenditures, is inequitable and can expose whole populations to huge cost burdens that block development and simply perpetuate the disease/poverty trap. On the other hand, health systems need financing and investment to improve their performance, yet this need cannot in turn impose an unfair burden on national spending or competitiveness.

This is a very delicate balance for policymakers to have to strike. There are other challenges too. For instance, in highincome countries, the lack of benefit portability associated with employerprovided health insurance often constrains worker mobility, so impeding the efficiency of labour markets we all want to see. And there are indirect effects on other spending decisions, both by households and governments. In other words, if you want to raise investment in health spending, you may need to find cuts elsewhere in the economic system.

As policymakers with public responsibilities, we must never forget that decisions taken in one sphere affect conditions, stakeholders and policies in another. We all want better health systems, but the impact of health on the economy should not be underestimated. Our challenge is to harmonise health and economic policies to improve health outcomes, of course, but also to minimise any negative impacts while promoting synergies wherever possible. We cannot do this alone and need the international evidence and shared learning that organisations like the OECD can provide.

\section{References}

- Visit Mexico's health ministry web site at: www.salud.gob.mx 


\section{To our future health}

Berglind Ásgeirsdóttir, OECD Deputy Secretary-General

\section{Health represents the single most important expenditure for OECD governments today, and our countries are spending record amounts on healthcare. But with cost pressures rising, how can we achieve value for money while continuing to improve quality? This is a vital question that health ministers will discuss at their ministerial conference on 13-14 May. The OECD Health Project has produced many answers, but it raises even more questions.}

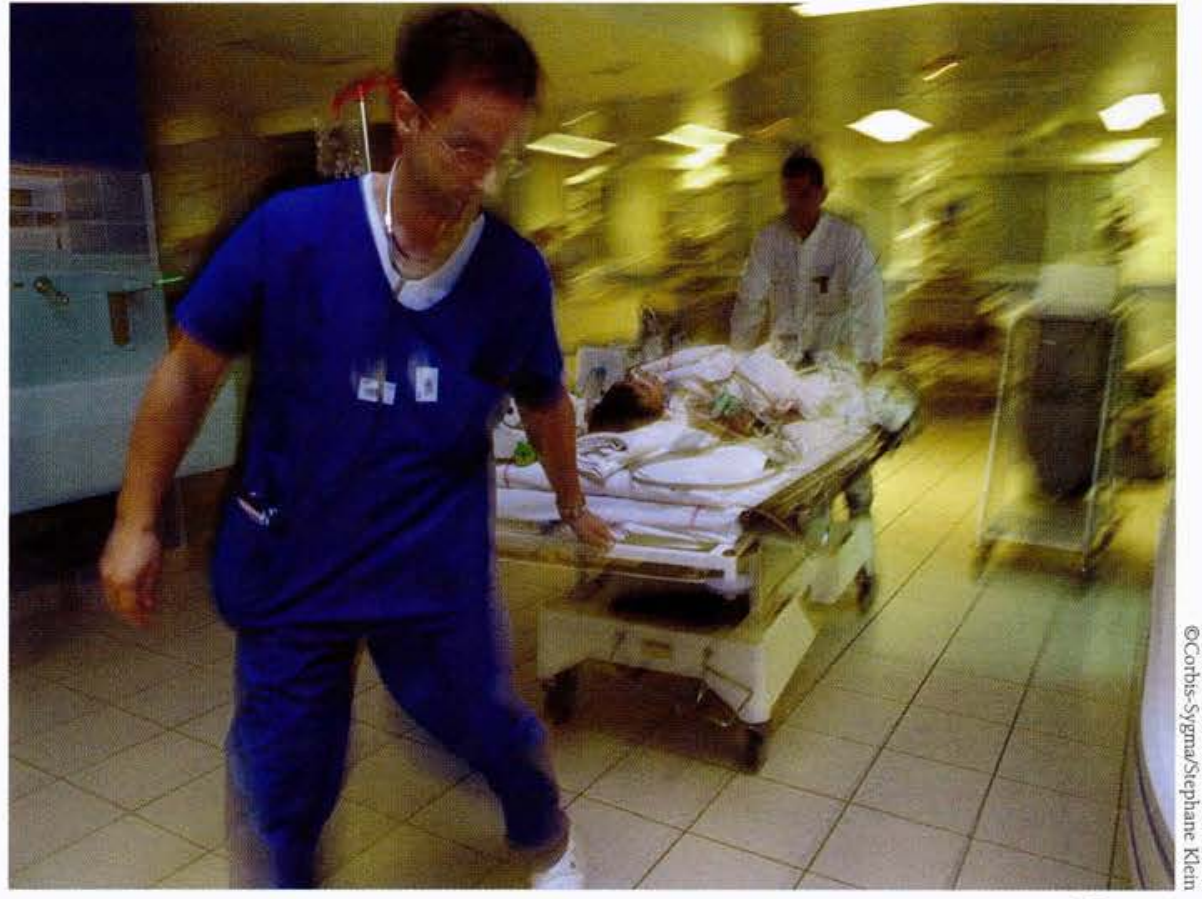

Urgent!

too. There have been recent major breakthroughs in prevention and treatment of conditions like heart disease, cancer and premature birth. Thanks to improved treatments, more patients can now live relatively normal and healthy lives with some chronic conditions, such as diabetes.

In most countries, universal healthcare coverage - whether publicly or privately financed - not only provides financial security against the costs of serious illness, but also promotes access to up-todate treatments and preventive services. Only a third of children in most OECD countries were immunised against measles 10 years ago, compared with $90 \%$ today.

These gains do not come cheap. Healthrelated spending exceeds $8 \%$ of GDP on average for the OECD area, and $10 \%$ in Switzerland and Germany. The US leads the field in healthcare spending, with $14 \%$ of GDP. Compare this with 1970 , when the OECD average was just $5 \%$ of GDP. Even the OECD's lowest spenders today in GDP terms - the Slovak Republic (5.7\%) and Mexico (6.1\%) - spend more.

Three quarters of OECD health spending comes from the public purse. Even in the US, where the private sector plays a major role in financing, public expenditure on health represents $6 \%$ of GDP. Much of the increase over the last 30 years has been generated by progress in medicine, with more expensive treatments, and the rise in expectations for healthcare from older, fitter populations.

Clearly, despite great strides, we can do better. No country has a perfect healthcare system. Take the case of France. It has excellent health status and 


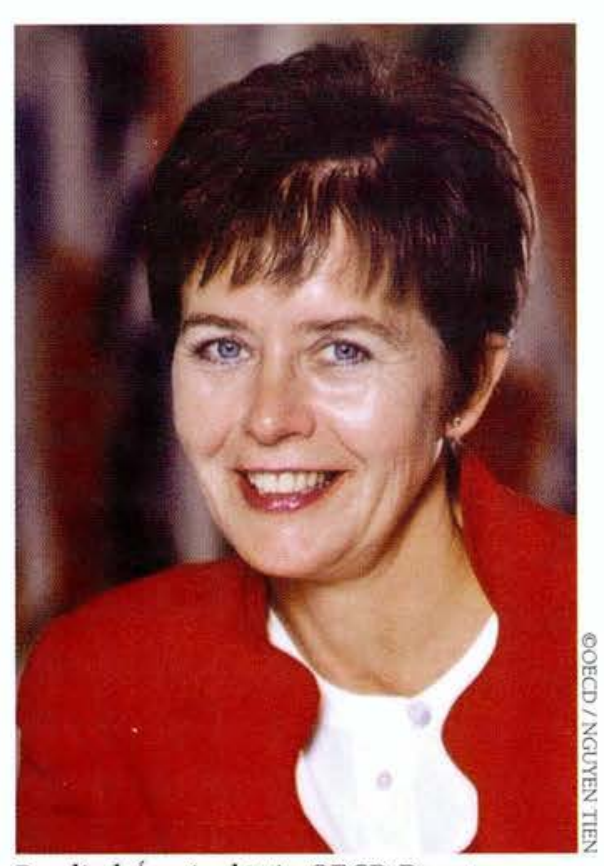

Berglind Ásgeirsdóttir, OECD Deputy Secretary-General

\section{Clearly, despite great strides, we can do better. No country has a perfect healthcare system.}

long life expectancies, as well as few waiting-list problems, but its public health financing is stretched. Despite this impressive record, the 2003 heat wave which ended in 15,000 deaths revealed organisational weaknesses that are now being addressed. The US is another example. For although Americans spend more than the average and are leaders in $R \& D$ and treatment innovation, achieving adequate access to services for all continues to pose serious challenges.

To understand these points is to grasp the spirit of the OECD Health Project, which was launched in 2001 to address the key challenges policymakers face in improving their healthcare systems. A desire for real progress and a need to fill important information gaps drove this collaborative project. It provided member countries with multiple opportunities to participate and learn from each other, through meetings of officials and experts.

Difficult questions were asked. What can be done to ensure that spending on health is affordable today and sustainable tomorrow? What is needed to improve quality and to ensure that health systems meet the demands of patients and other stakeholders? How should equitable and timely access to necessary care be supported?

The Health Project encompasses studies addressing these key policy questions, focusing on health technologies, longterm care, private health insurance, cost control, equity of access, waiting times, and more.

We have learned many basic lessons. For instance, it is important not to overlook opportunities to think outside the box of mainstream policy levers. Improving health also means addressing issues such as violence, accident prevention and worker safety, road traffic enforcement, and the use of drugs, alcohol and tobacco.

While curative medicine is vital, preventive action should not be underestimated. Just $5 \%$ of healthcare spending goes towards initiatives designed to keep people healthy. Health has improved thanks to public awareness campaigns, regulation and taxation, and the reduction of smoking, for example. New challenges emerge, with the current rise in obesity in several OECD countries being a common concern. More could and should be done. It is important not to lose sight of the value of personal responsibility in healthcare.

Everyone wants to see improved quality in healthcare, and to ensure appropriate treatments are available. For example, medicines to control hypertension are often not prescribed when they should be, and more heart attack patients could be prescribed a simple aspirin. Differences across countries in outcomes for conditions like stroke and breast cancer might be explained by the intensity of treatments, the technical quality of care, and so on.

The Health Project found organisation to be vitally important. Good organisation prevents some accidents and mistakes from happening, for instance. Better systems for recording data on patients help make leaps in quality, as demonstrated by hospitals in Australia and the US that have adopted automated systems for placing medication orders.

Physicians and hospitals need to be given incentives to take on the cost of investing in such systems. But they should not be burdened with management to the detriment of delivering proper healthcare for all.

Indeed, the job of providing universal care is already complicated by shortages of nurses and physicians in many countries. In some countries, increasing nurses' pay and improving working conditions could help, as could focusing on raising productivity through training. Hiring from abroad has also helped, though some countries now discourage recruitment campaigns targeting developing countries to avert a "brain drain".

Accessibility is a major concern in all countries. It is influenced by many factors, such as the effect of user fees, differences in insurance coverage across 
the population, geography, and so on. Policy can mitigate these inequities, although measures can be costly. Excessive waiting times for elective surgery are a source of public dissatisfaction, too. The most common solution is to increase either capacity or productivity, though again, better organisation also helps, such as by prioritising patients in greatest need.

Offering choice in health coverage can result in a more responsive health system. The very availability of publicly or privately financed options provides some options. However, we also know that multi-payer systems can raise cost pressures and lead to inequities.

Every solution carries risks and striking a balance is not easy. But the bottom line is that society is ageing, and the burden on public finances cannot be expected to rise forever. This may mean that individuals will have to fund more of their own healthcare. This is already happening in some countries, though again there are challenges, since vulnerable populations have to be looked after.
Private health insurance can offset some public spending, but even in countries where a sizeable share of the population is privately insured, this is sometimes concentrated on lower-risk cases, as these are less costly to insure.

Ultimately, increasing efficiency may be the only way of reconciling rising demands for healthcare with financing constraints. Changing how funding is spent, rather than mere cost-cutting, is the key. Payment methods for healthcare providers have moved away from costreimbursement, which encourages inefficiency, towards activity-based payments rewarding productivity. But these systems also introduce risks, such as that of encouraging services of low or marginal health benefits, even if generous in terms of reimbursements.

Shifts in responsibility can also reduce waste and increase productivity. Certain qualified nurse practitioners might take on certain duties performed by physicians, and so on. In long-term care, which is a source of growing disquiet in ageing societies, existing funding could be

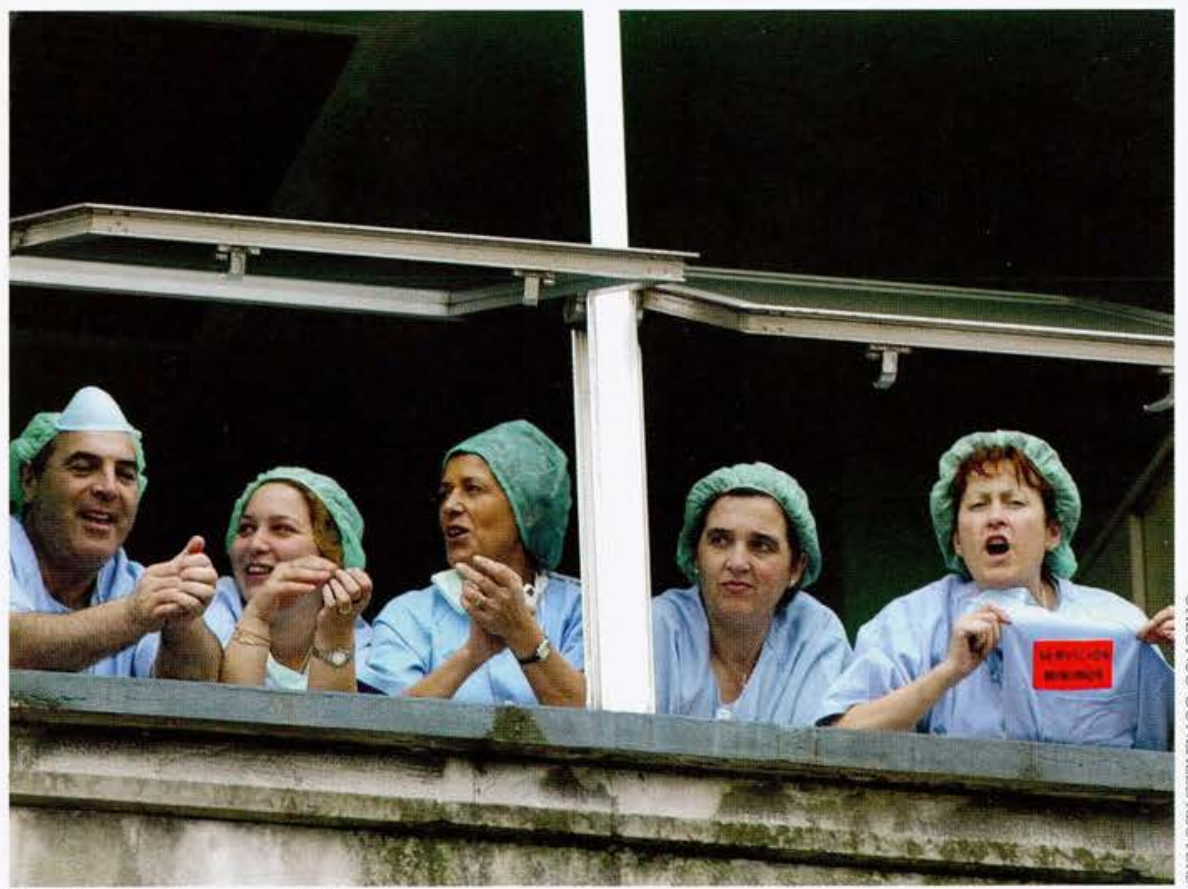

Looking for better conditions used to help patients receive care at home, rather than in an institution.

Clearly, health experts in OECD countries now know quite a bit about which tools and approaches can be used to accomplish many key policy objectives, such as improving quality of care, ensuring equitable access and increasing value for money. Reform of health systems is necessarily an ongoing process and there are few quick fixes. Health strategies involve making trade-offs, as well as handling uncertainty. Nor is promoting health the only consideration, and policies to reform the health sector - a major employer in many countries - can carry economic and social repercussions.

Not all countries will respond to the findings of the Health Project in the same way, as they do not all face the same challenges and anyway, there are no onesize-fits-all solutions. Some countries enjoy good health outcomes and so want to maintain standards while generating savings as well. Others will want to find ways of improving outcomes by reorganising existing resources. A few countries may find they need to invest more money to lift quality. But whatever the policy mix, the Health Project results offer a valuable resource of facts, data and observations garnered from different health systems. They serve as a benchmark for deciding what works best for each situation.

There is still so much we do not know, about advances in medical technology, dealing with certain diseases or even how to assure a sustainable supply of personnel. But the OECD Health Project has investigated the nature and extent of many of the problems and provided us with some of the answers. As with healthcare itself, it is an ongoing task, and there are many questions we must pursue. That means gathering more data and finding more time to think and discuss. Our citizens demand it, and rightly so. After all, it is not only their money, it is their lives.

\section{References}

- For more on the OECD Health Project and other OECD work on health: www.oecd.org/health

- OECD (2003), Health at a Glance, Paris 


\section{Can new infectious diseases be stopped? Lessons from SARS and avian influenza}

Anarfi Asamoa-Baah, Assistant Director-General, Communicable Diseases, World Health Organization

Infectious diseases can emerge and spread with deadly and debilitating effects. But they can be stopped, as experience from SARS shows.

S evere acute respiratory syndrome (SARS) has often been described as the first serious new disease to emerge in the 21 st century. As such, it fulfilled some of the prophecies made following another "first" for this century: the deliberate distribution, in an act of bioterrorism, of anthrax spores through the US postal system in late 2001. That previously unthinkable event opened the eyes of politicians and the public to the damage that an infectious disease - whether of deliberate or natural origin - could cause in a highly mobile and closely interconnected world. It focused attention on several features of "modern" infectious diseases that make outbreaks, whatever their cause, an especially ominous threat. These include silent incubation periods that allow microbes to hide, unsuspected and undetected, in travellers, the speed of international spread made possible by the volume of air travel, and the potential for

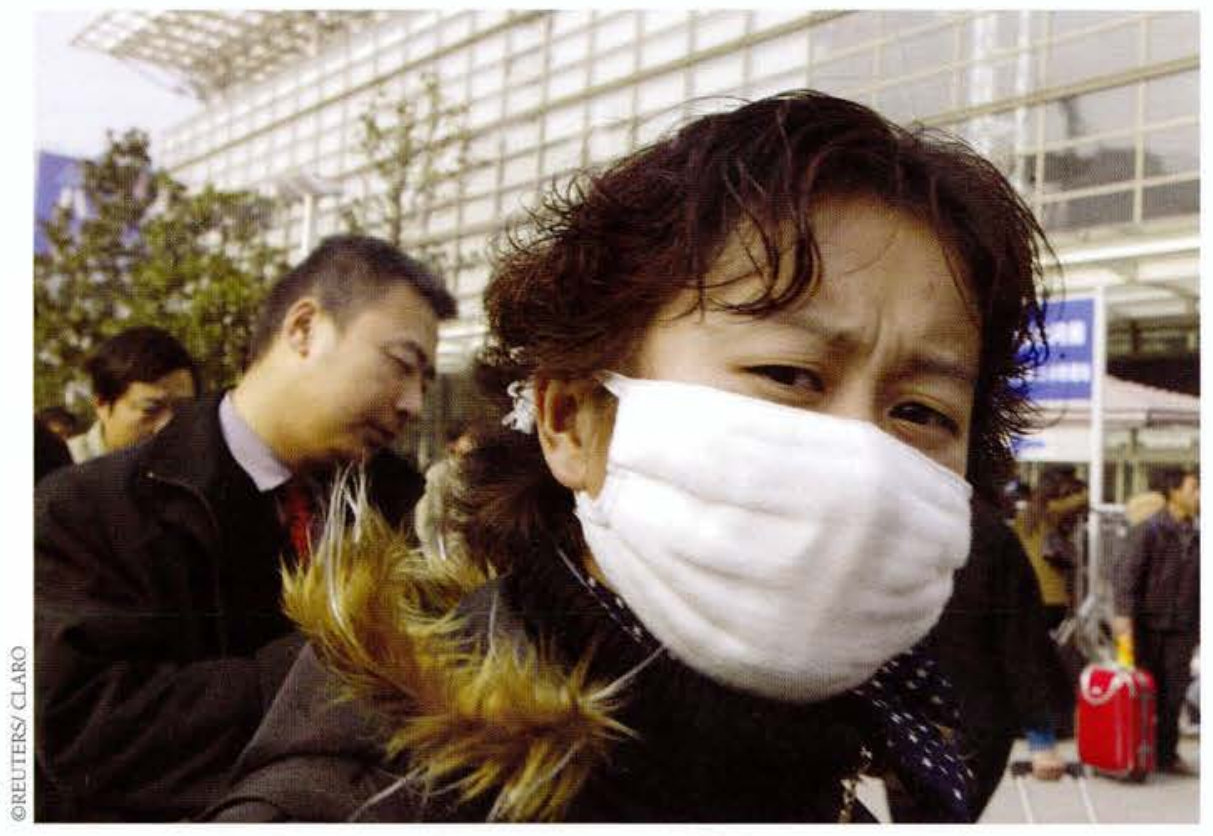

social and economic disruption amplified by electronic communications and the close interdependence of economies. Many scenarios were developed to predict the magnitude of illness and disruption following the deliberate spread of a disease, such as smallpox, having a long incubation period, a high fatality rate and no cure.

SARS had all of these features and more. Beginning in February 2003, it spread rapidly along the routes of worldwide air travel, placing any country with an international airport at risk. It had neither a vaccine nor an effective treatment, and killed upwards of one out of every ten persons it infected. It mimicked the symptoms of many other diseases, making diagnosis difficult, took its heaviest toll on healthcare staff, and spread most efficiently in hospitals. It also defied certain longstanding assumptions about the impact of epidemic-prone diseases in wealthy nations, and set an important test: can an emerging disease be stopped?

Events during the final decades of the 20th century had quickly eroded confidence that infectious diseases could be easily conquered. Beginning in the 1970 s, the rapid development and spread of drug resistance rendered one antibiotic after another useless. Ebola haemorrhagic fever emerged in Africa in 1976, marking the most dramatic and potentially explosive epidemic of a new viral disease seen in the world for more than 30 years. In the early 1980s, AIDS struck, spread around 
the world, and rapidly became entrenched, eventually creating the greatest humanitarian crisis in history. Altogether, 40 new disease agents were detected during the last three decades.

Although the vulnerability of all nations to the infectious disease threat was widely accepted by the start of this century, many experts believed that new infectious diseases would not take hold with devastating effect in affluent nations. In these nations, the consequences of AIDS were greatly diminished by the advent of antiretroviral drugs and their wide availability. Most other new diseases with high fatality, including the Ebola, Marburg, and Lassa haemorrhagic fevers, were considered diseases of poverty and poorly-equipped hospitals. Good sanitation and infection control, it was felt, would protect populations in the industrialised world from the devastation caused by epidemic-prone diseases in other parts of the world.

SARS proved otherwise. Good sanitation and high standards of healthcare were no protection. In fact, the spread of SARS was most efficient in sophisticated healthcare settings where certain medical procedures greatly increased the risk of transmission. SARS also showed how, in a closely interconnected and interdependent world, a deadly and poorly understood new disease can adversely affect economic growth, trade, tourism, business performance, political careers and social stability.

The public image of SARS was a white mask. The most vivid images of its economic impact were those of empty airports and strangely quiet city streets. SARS changed the way economists estimate disease-related economic losses. Previously, such estimates were based primarily on the costs of medical treatment, absenteeism from work and lost productivity. Efforts to calculate the full economic costs of SARS are ongoing, but range from US\$30 billion to $\$ 100$ billion, largely measured in terms of lost trade and foreign investment.

The consequences of SARS in affluent countries were devastating, but short-lived. The World Health Organization (WHO) first alerted the world to the new disease in mid-March 2003. From the outset, the objective was to seal off opportunities for its further spread, interrupt transmission, and prevent the new disease from becoming permanently established as yet another threat to global health. The experience with AIDS taught the world that the best response to a new disease is an allout effort to prevent it from becoming established in the first place. Fortunately, the international community was much better prepared for SARS than it was when Ebola or AIDS emerged. The response to SARS demonstrated some of the positive
The possibility, opened by SARS, that emerging diseases might be stopped has given the roles of national and international surveillance for epidemic-prone diseases even greater importance. Surveillance systems for SARS are still on alert.

A new, though different, scare came in January 2004, when clinicians in Vietnam detected an unusual number of cases of severe respiratory illness, with high fatality and an unknown cause, at a hospital in Hanoi. The WHO was promptly informed, and its network of laboratories identified the cause as an

\section{The spread of SARS was most efficient in sophisticated health care settings where certain medical procedures greatly increased the risk of transmission.}

features of a globalised society: the advantages of rapid electronic communications and new information technologies for emergency response, and the willingness of the international community to form a united front against a common threat.

The possibility of stopping SARS "dead in its tracks" brought full support at levels ranging from heads of state to community volunteers, and in forms ranging from the electronic exchange of electron micrographs of the virus to mass distribution of thermometers. The willingness of the world's best laboratory scientists, clinicians and epidemiologists to collaborate in around-the-clock "virtual" networks played a decisive role in generating knowledge and solving mysteries as the disease progressed. Within a month, the causative agent - a new corona virus unlike any known before - had been identified. In less than four months following the first global alert, the WHO was able to announce, on 5 July 2003, that all known chains of human-to-human transmission had been broken. Ironically, the first new disease of the 21 st century had been brought to bay using 19th century control tools - case detection, isolation, quarantine, infection control, and contact tracing - amplified by the latest communication technologies. especially deadly influenza virus that normally infects bird species exclusively. That finding caused Asian nations, and eventually the entire world, to increase their vigilance for cases of severe avian influenza in poultry and humans which could herald the start of another epidemic. It also encouraged governments to develop or strengthen pandemic preparedness plans and to find ways to use the unprecedented international collaboration seen during SARS to protect the world against other threats.

Future efforts to stop new diseases can draw three lessons from these experiences. First, good surveillance at both national and international levels is essential. Second, since infectious diseases potentially threaten every country, it is in every country's best self-interest to collaborate internationally. Finally, international co-ordination - whether under the WHO's leadership or the guidance of the International Health Regulations - is needed to ensure that our collective efforts bring the best results for international health.

\section{References}

- Visit http://www.who.org

- "Biotechnology and Sustainability: The Fight against Infectious Diseases": http:/www.oecd.org/ dataOECD/23/23/2508407.pdf 


\section{Health}

\section{Living with cancer}

Andrew C. von Eschenbach, Director, US National Cancer Institute



Surgery of the future?

\section{Eliminating suffering and} death due to cancer is now not only possible, but the National Cancer Institute in the US has set it as a goal.
$\mathrm{T}$ his is a pivotal time in the fight against cancer. Since the National Cancer Act of 1971, the United States has made conquering cancer a national priority. The great strides made in research have led to the understanding that cancer, once a seemingly mysterious and unconquerable foe, is a disease process whose mechanisms can be elucidated and controlled.

Based on such progress and possibilities, I have issued a challenge to our entire cancer community: to eliminate suffering and death due to cancer in the US by 2015. We may not eliminate cancer, but by accelerating progress to prevent, detect and control cancer, we can pre-empt its tragic outcome.

Our ever-increasing understanding of the genetic, molecular and cellular aberrations involved in the onset and progression of cancer is providing the targets for intervention that can help us develop 
personalised, integrated, mechanismbased interventions. The example of the recent successes in chronic lymphocytic leukemia (CLL) and gastrointestinal stromal tumour (GIST) by using a targeted kinase inhibitor is only the first chapter in a rapidly unfolding story.

Already we have seen rapid drug approval by our Food and Drug Administration (FDA) of an angiogenesis inhibitor, proteosome inhibitor, and epidermal growth factor receptor inhibitor: Avastin, Velcade and Erbitux, respectively. Many other success stories are expected, with potentially profound impact on reducing cancer deaths. Understanding metastasis of cancer and the interaction of the cancer cell with its microenvironment and host alone can save millions of lives.

Unraveling the origins of cancer has led to the understanding that the outcome of the disease is a highly complex process. We are now at a magic moment when the expansion and integration of our knowledge is accelerating at a breathtaking pace. We must manage this scientific and clinical enterprise.

Our strategy is to embrace, integrate and modulate the biologic impact of that intervention in real time. Monitoring tumour shrinkage on a chest X-ray three months after treatment will give way to visualising tumours with devices such as PET scanning and short-lived isotopes. These detect alterations in gene expression, signaling pathways and creating the ability for precise, individualised targeted therapies. Largescale team research projects will combine diverse groups of experts to fuse their insights and develop innovative strategies. Advanced bioinformatics platforms, such as the cancer Biomedical Informatics Grid (caBIG), will connect and support the biomedical research community.

New technologies like nanotechnology will complement genomic and proteomic research and accelerate our ability to prevent, detect and treat cancer (see Databank). The onset of premalignant and malignant transformation will be detected at the molecular level long before the anatomic presence of a tumour is discernible. This will permit less drastic methods of elimination.

A greater understanding of the human

We are now at a magic moment where the expansion and integration of our knowledge is accelerating at a breathtaking pace.

expand a continuum based on Discovery, Development and Delivery. Accelerated discovery will generate new information about cancer at the genetic, cellular, individual and population levels. This knowledge will guide the development of new therapies that are targeted, specific and individualised. In addition, we will develop more specific methods of detection and prediction of cancer behaviour based on the genomic and proteomic signatures of tumour types. Diagnostic devices will no longer detect just physical presence but will "visualise" the molecular biology of the disease.

To achieve our goal, we must deliver these new interventions. Delivery will no longer merely be the application of an intervention, but we will monitor and biology of cancer revealed from patients will complement and stimulate new laboratory investigations in vitro and in silico, linking delivery back to discovery in the continuum. Tomorrow's patients will know their susceptibility to cancer and the lifestyle factors needed to keep healthy. Together with their physicians they can develop a personalised pathway to successful cancer prevention.

To achieve our 2015 goal of eliminating the suffering and death due to cancer, we must act now to foster strategic opportunities. Our focus on molecular epidemiology and gene/environment interactions will help determine populations at risk. An emphasis on integrative cancer biology will permit a systems approach to understand the cancer process. An integrated clinical trials system with a common bioinformatics grid will rapidly test and validate new strategies for early detection, prevention and prediction of cancer.

In short, the new research paradigm of scientific discovery, rapid development, and delivery of effective interventions to all populations hinges on: interdisciplinary science; an integrated, multifaceted set of tactics; immediate application of new technologies; information sharing; and close links to health delivery systems.

There is one critical element in this pathway to progress that underpins the success and pace of the initiative - the application and development of innovative technologies. The development of tools in genomics, proteomics, molecular imaging, bioinformatics, nanotechnology, and other advanced technologies is a critical step. The US NCI will pursue a complementary strategy to our Discovery, Development and Delivery continuum, namely, the creation of a National Advanced Biomedical Technologies Initiative for Cancer. This effort will wed academic centres of cancer research and care with centres of technology development, to apply and develop essential tools to complete the task

The National Cancer Act of 1971 put the process in motion and today we have the opportunity and the responsibility to fulfil the promise. Cancer is not a national problem, but rather a global one. We are privileged to do our part and share with the world the opportunity to make cancer a disease that we will live with, rather than die from. We must and will maintain the momentum. We owe it to all of those who will be diagnosed with cancer in their lifetime.

\section{References}

- US National Cancer Institute: http: //www.cancer.gov

- Cancer Biomedical Informatics Grid (caBIG): http://cabig.nci.nih.gov/

- National Advanced Biomedical Technologies Initiative for Cancer: http:/www.cancer.gov/directorscorner/ 
$\mathbf{A}+\mathbf{B}+\mathbf{C}$
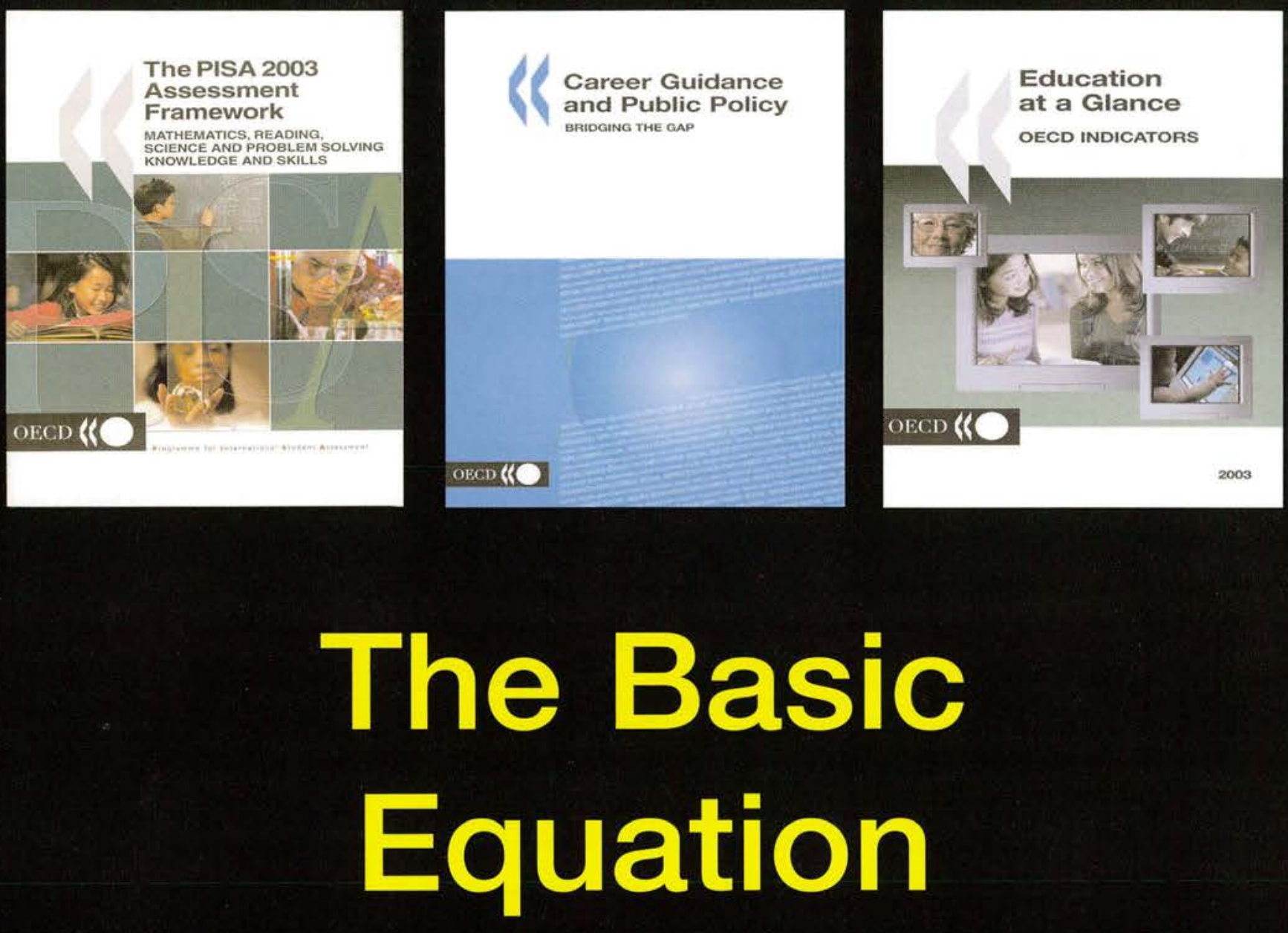

\section{Read OECD publications on education www.oecd.org/bookshop}

To be the first to know about new OECD publications on education, sign up for OECDDirect, our free e-mail alert service: www.oecd.org/OECDDirect 


\section{Road safety \\ Making roads healthy}

Jack Short, Secretary-General, European Conference of Ministers of Transport*

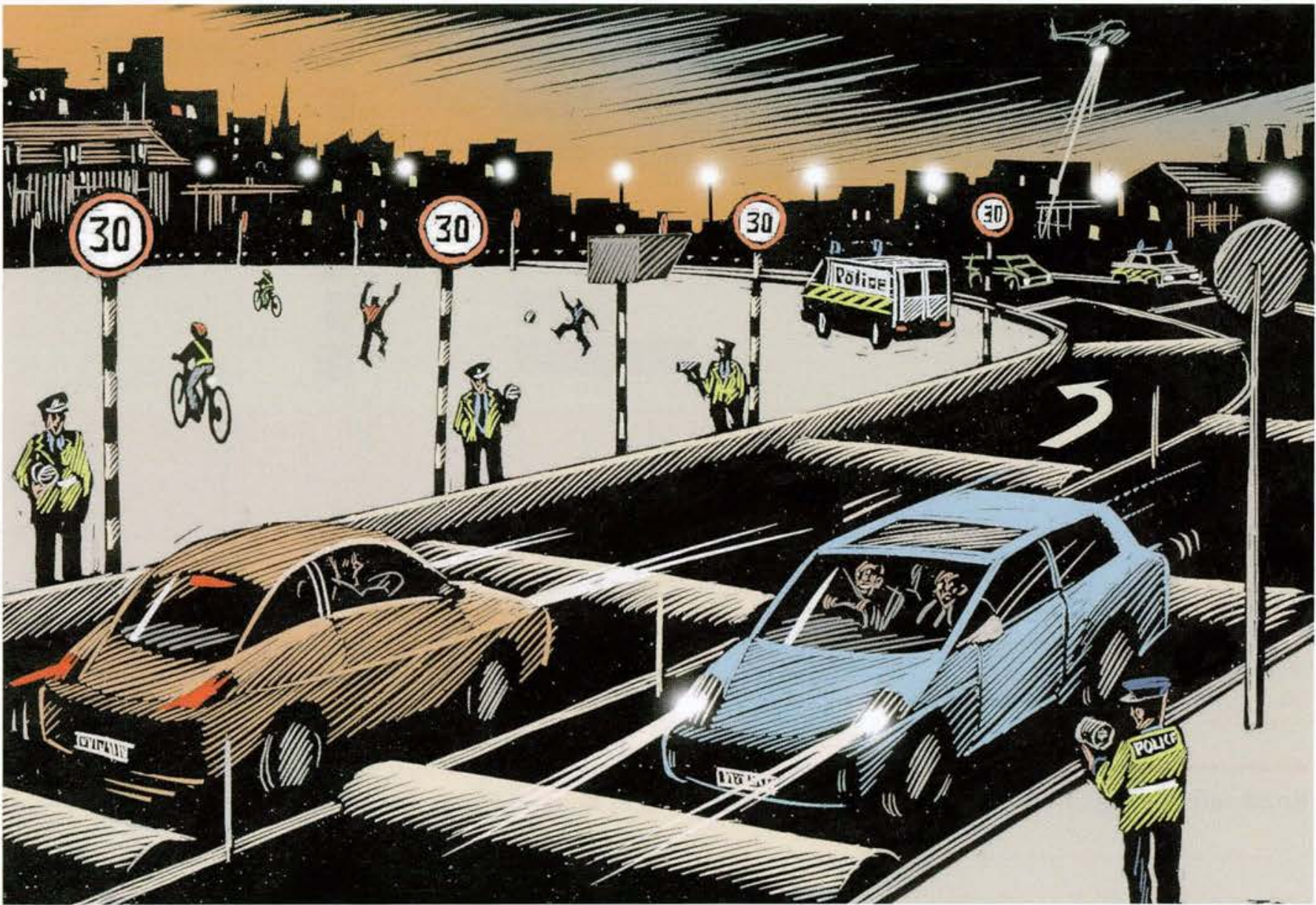

Road crashes are a major health issue. The ECMT has set a goal of halving the number of deaths on the roads in its member countries by 2012 . A serious challenge.
T very year, 1.2 million people are

$\square$ killed worldwide as a result of road are injured. Most of these are in non-OECD countries, but no one can feel complacent. In Europe, more than 100,000 people die, while a further 2 million people are injured. Road accidents are the principal cause of death for young men under 25 .
Nor do road accidents come cheap. There are high costs in terms of lost productive capacity and human capital, be it for fatalities or injuries. Add to this the medical and non-medical rehabilitation expenses. Some costs are less obvious: broken families, the loss of a wage-earner, even the cost of counselling. And of course, damage to property has to be paid for. Some 


\section{Health}

estimates put the total economic loss resulting from road deaths and injuries at a remarkable $2-3 \%$ of GDP in OECD countries.

This makes road safety a serious public health issue. So much so that the World Health Organization made road safety the theme of this year's World Health Day on 7 April. UN Secretary-General Kofi Annan seized on this opportunity to remind people that road traffic injuries can be prevented, but only with deliberate action from many sectors of society, including transport, education, health and law enforcement. He cited France, historically one of the worst countries in Europe for road fatalities, as an example of what can be achieved.

Since 2002, road safety has been tightened and the number of road traffic deaths has been cut by $20 \%$

This is an encouraging decline, and the European Conference of Ministers of Transport (ECMT) is taking a lead to ensure such progress continues. For many years the ECMT has worked towards cutting down on the number of road accidents by publishing comparative data, by making governments aware of best practice and by drawing up recommendations for action.

To this effect, the ECMT Council of Ministers unanimously agreed to set a target in 2002 to cut the number of road deaths by $50 \%$ by the year 2012 . This is a laudable, though highly ambitious, goal, in view of discouraging trends in some countries, particularly Russia.

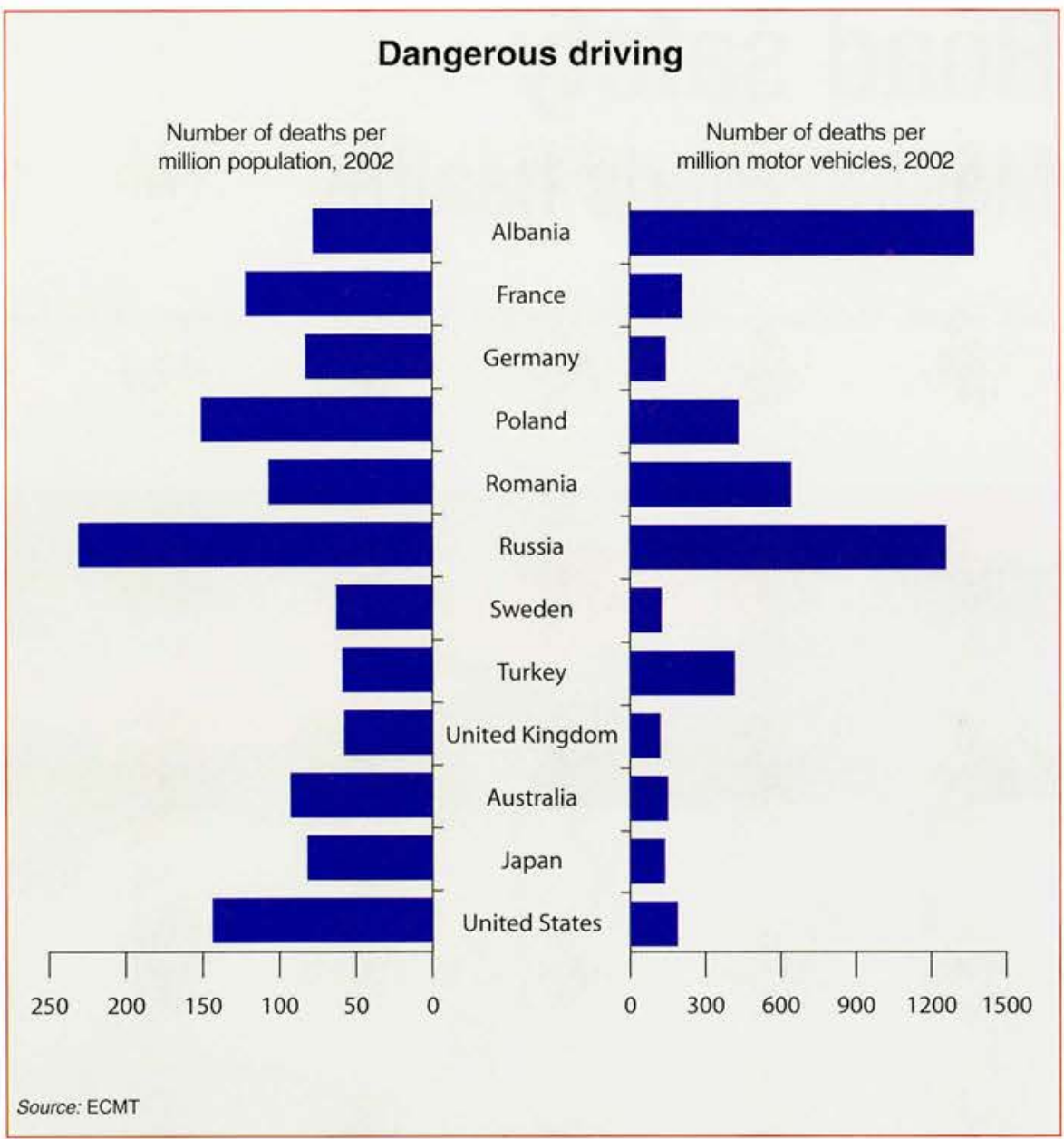

the goal of halving fatalities will be presented at the next ECMT Council of Ministers meeting in Ljubljana on 26-27 May. These measures are grouped under three main themes: expanding the

Every year a survey will assess progress. Data will be gathered, lessons learned and experiences shared. In this way we will show that, while the car may be essential in our lives, road deaths are not a fatality.

* The ECMT, established in 1953, is an intergovernmental organisation grouping 43 European member countries, 7 associate countries and 1 observer country. It is a forum in which ministers responsible for transport, particularly the inland transport sector, can discuss current problems, co-operate on policy and agree on joint approaches aimed at improving and developing European transport systems.

the field of research; and providing finance and management. Road safety programmes do not have to be expensive to be efficient. In fact, there are cost-effective tools available that can make a serious difference, such as a gradual introduction to driving; penalty points systems; random breathtesting for alcohol; and even clearer road marking, to list just a few.

\section{References}

- ECMT (2003), Road Safety: Impact of New Technologies, OECD, Paris.

- ECMT (2002), Safety on Roads: What's the Vision?, OECD, Paris.

- For more on road safety and other work from ECMT, visit www.oecd.org/cem or contact Martine-Sophie.Fouvez@oecd.org. 


\section{Biotech}

\section{and the pharmaceutical industry Back to the future}

Marcia A. Kean, Chief Executive Officer of Feinstein Kean Healthcare*

\author{
Biotech is set for a great \\ future in healthcare. Here \\ is why.
}

$\mathrm{T}$

he history of business enterprise is filled with heroes and villains. In the 20 th century, we had our pick of industries to hate, including cigarette purveyors, alcohol producers, automobile manufacturers, and so on, that could be accused of damaging our health, polluting our air, endangering our children or, in general, putting their profits above society's well-being.

Several decades later, we are pleased to have a new "villain" on which to pour our disdain: the global pharmaceutical industry, usually known as Big Pharma. Its sin? The generation of profits from the discovery, manufacture and sale of products that treat (and sometimes cure) the plethora of ills that befall mankind, from arthritis to asthma to cancer to diabetes to cardiovascular disease to neurodegeneration - in fact, treatments for virtually every organ system in the body.

So far, the younger sibling of pharmaceuticals, the biotech industry, is still the golden-haired child when it reports on scientific innovation and drives new jobs and economic well-being in select "biocluster" regions. But upon coming of age and reaching the market with new and high-value products, individual biotech companies soon find themselves similarly vilified for exploiting their unwary "victims" (i.e., sick people, who presumably benefit from new therapies) by charging for their products.

Where is society's uneasy relationship with the biotech and pharmaceutical industry headed?

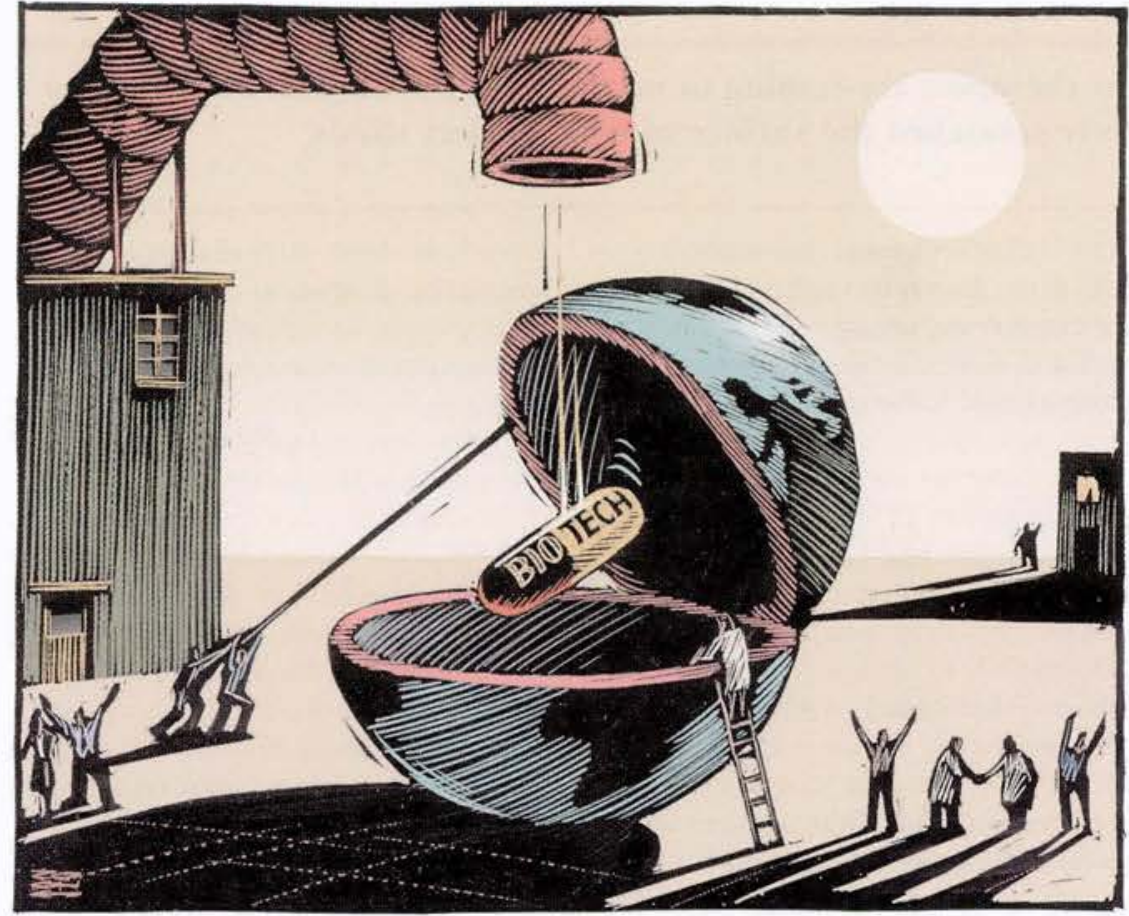

I can foresee a wonderful, exciting new future - almost imminent - in which several primary drivers lead to a halcyon era of drug R\&D productivity, resulting in a new generation of products for improved healthcare, finally ending in broad-based public acceptance of the combined (bio)pharmaceutical industry. These independent and yet interwoven drivers are: the tidal wave of new knowledge about the molecular mechanisms of disease that has emerged since the watershed Mapping of the Human Genome and subsequently accelerated with the advent of the "omics" (genomics, proteomics, etc.); a new toolkit of high-speed technologies for biological target identification and generation of new chemical entities for assessment as potential products; the growing annual R\&D expenditure by pharmaceutical companies worldwide, which in 2002 exceeded US\$45 billion according to the International Federation of Pharmaceutical Manufacturers Associations, (IFPMA); and a "new" deal among the three interconnected pillars of academic/government research, industry and healthcare providers in which collaboration starts earlier, lasts longer, and involves true interdisciplinary co-operation the "so-called" bench-to-bedside model.

Starry-eyed? Maybe, but consider these six points:

First, the entrepreneurial, market-driven $R \& D$ model definitely works for healthcare 
Health

innovation. New therapies are coming to market to address intractable disease enemies such as stroke, Alzheimer's, cancer, traumatic brain injury, etc. And the industry has barely scratched the surface of what society needs.

Second, the biotech industry has delivered. About 100 biotech-derived drugs have already come to market, and another 350-400 therapeutic candidates are in the pipeline. Moreover, biotech is growing up, and is no longer viewed as a poor relation of large pharmaceutical companies. Big Pharma now seeks out biotech innovation at its source (why else have so many multinational there are clear signs that the generation that has transformed society at every step from nursery school through middle age will soon take on the challenge of how to address the infirmities of old age.

Next point: Molecular Medicine (aka pharmacogenomics: personalised medicine) is evolving faster than you think. New products are in development that will redefine your disease (i.e., my form of cancer and your form of cancer, although they look alike at the clinical level, are different at the molecular level, predisposing us to different responses to treatment and

\section{New therapies are coming to market, but the biotech industry has barely scratched the surface of what society needs.}

pharma companies located their research centres in the geographic cradles of biotech?). Once strangers and uneasy collaborators, biotech and pharma are finally experiencing the long-awaited "convergence".

The third point: we are getting older. As the population ages in all the major industrial nations, palliative healthcare (mainly in nursing homes) will become an economic nightmare; only drug therapies to treat - and hopefully to prevent - chronic and debilitating illness, such as Alzheimer's disease, will have a chance of changing that. The 70 million Americans born just after the Second World War and their tens of millions of European counterparts who will reach "senior citizenship" over the next five years will see this first hand. Already, clinical outcomes). More of these "companion" diagnostics and therapeutics are on the way, heralding the end of the "one-size-fits-all" pharmaceutical paradigm.

Fifth, information technology giants such as IBM have made a major commitment to life sciences. As medicine shifts to a truly information-based discipline, sooner or later it will become faster and more cost-effective to discover and develop the right medication for the right patient. The biorepositories established at the national level throughout Europe and soon in the US, are facilitating this shift by bridging the gap between basic biological research and clinical development of new drugs.

Finally, many of the requisite technology tools are in place. A huge restructuring of the entire pharmaceutical $R \& D$ process has occurred. No, we have not seen the output hit the pharmacies yet, but it is not hard to imagine that in another three to five years, a "boomlet" of new gene-based products should be coming out of clinical trials and headed for the marketplace.

This salutary list of facts and trends notwithstanding, there are huge problems in the healthcare system that cannot be addressed solely by new pharmaceutical products, even those for the most intractable diseases. These problems will no doubt be addressed in coming years through a variety of policy changes and reforms. But in the meantime, let us not demonise those imperfect people who stubbornly refuse to stop... well... making a go of innovation and dedicating themselves relentlessly to making sick people well in spite of the tremendous scientific challenges and business risks associated with pharmaceutical R\&D.

So, who should care about these advances and wish to ensure that this new and exciting future actually happens?

It is a very short list: we all should. Because pharmaceutical and biotech companies are the heroes, not the villains, that will shape healthcare for us in the 21 st century.
" Feinstein Kean Healthcare is a consulting firm specialising in the life sciences, based in Cambridge, Massachusetts, US.

\section{References}

- See the Feinstein Kean Healthcare web site at www.fkhealth.com

\section{Frankie.org by siik \#4}
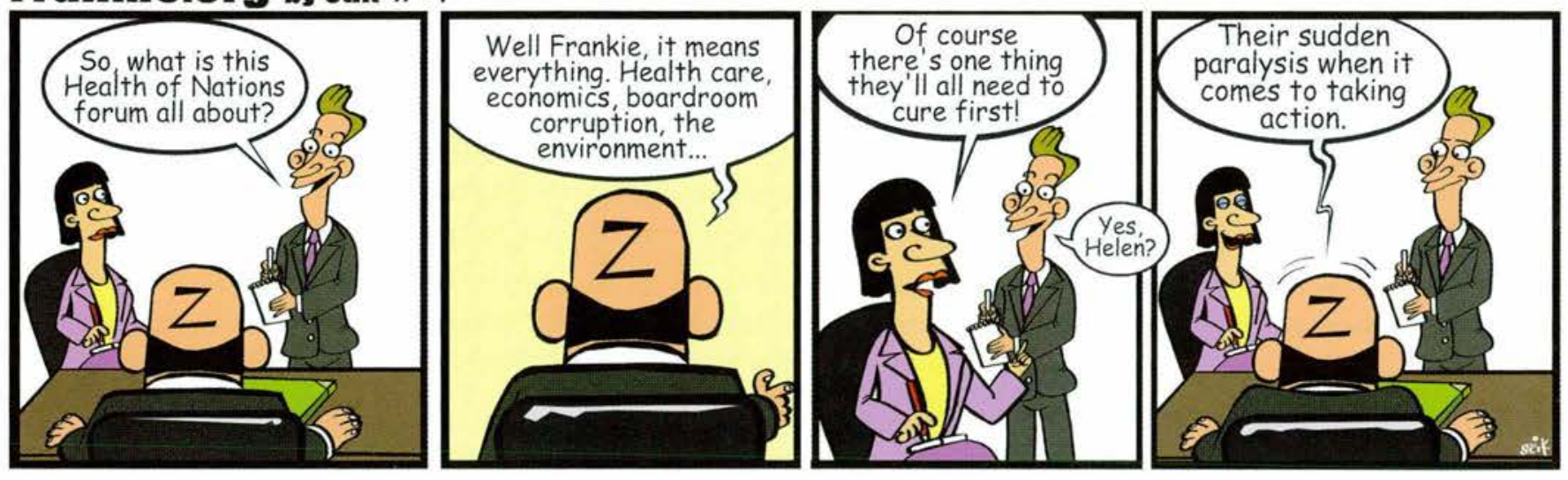


\section{Towards a healthy multilateral system}

Guy Ryder, General Secretary, International Confederation of Free Trade Unions (ICFTU)

\section{The globalisation of recent decades has been associated with worsening income inequality, increasing violations of fundamental workers' rights, environmental degradation and enduring abject poverty. While the OECD} Forum 2004 has as its theme the "Health of Nations", for much of the world's population, the global economy is not working.

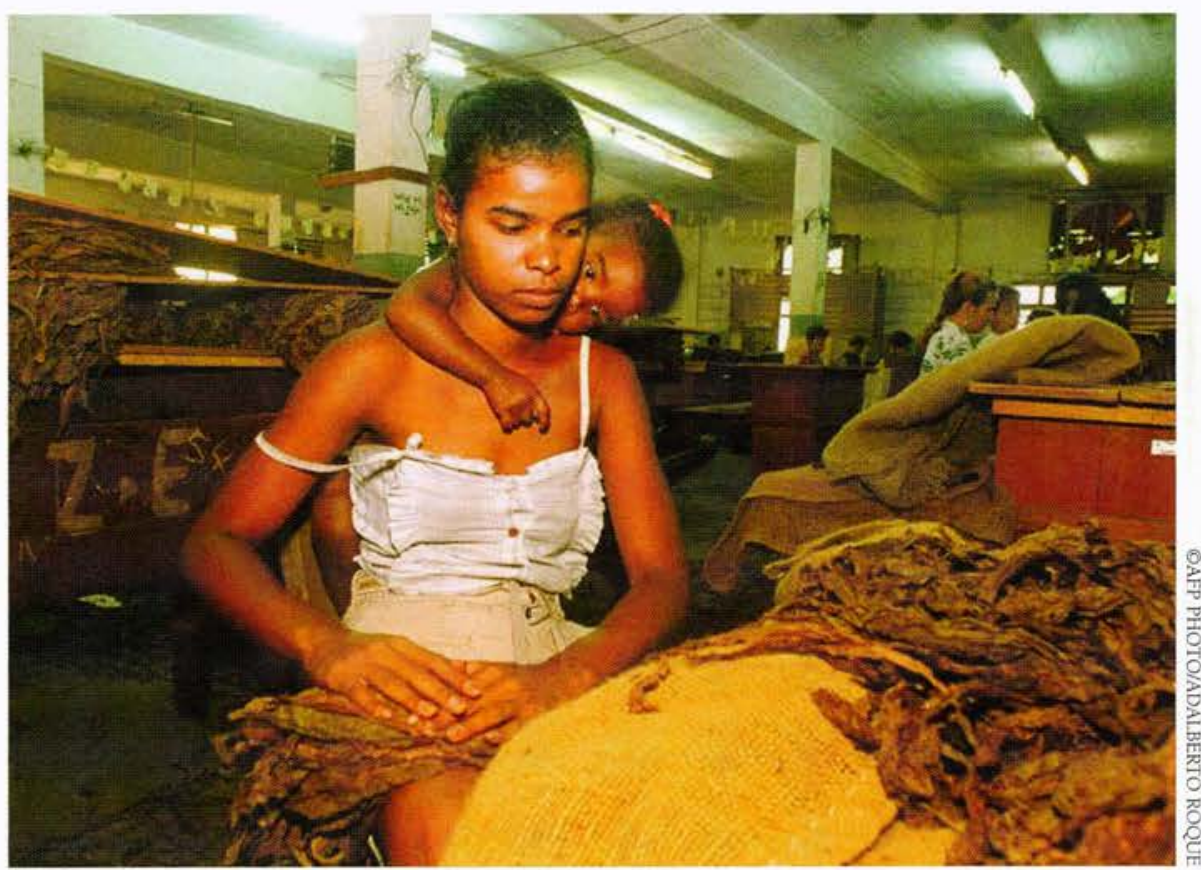

towards the eradication of world poverty - will never be attained by the target year of 2015

volatile: extreme currency swings and the risk of stock market

collapse are a recurrent feature, bearing an extreme cost in terms of poverty and unemployment. According to the World Bank's Global Economic Prospects 2004, the number of people surviving on less than US $\$ 2$ a day has reached 2.7 billion.

Such problems are most keenly felt in the highly indebted countries of the developing and transition regions, particularly the least developed. Although all the world's nations adopted the Millennium Development Goals (MDGs) in 2000, it is clear to everyone that, barring exceptional efforts, those goals - themselves only a step on the way
Another contemporary problem relates very directly to the globalisation of world trade, and to the unintended consequences of the trade liberalisation that has been agreed at the World Trade Organization (WTO). In 2004 and over coming years, tens of millions of jobs in developing countries will be lost as the barriers to textiles and clothing trade come down and world production gets increasingly concentrated in just one or two locations, particularly in China. In other words, a decision that was promoted as a means of helping developing countries to increase their exports and, by extension, their peoples' standards of living is going to have quite contrary results in many of the world's poorest countries.

These problems bespeak a fundamental incoherence in the world's multilateral architecture. While leaders may make a genuine commitment in one forum to achieving a commendable policy goal, there has never been adequate interinstitutional dialogue to translate that commitment into actions elsewhere in the international system to achieve the intended results.

In February 2004, a remarkable document was published that seeks to address this undesirable status quo. The report of the 
Health

World Commission on the Social Dimension of Globalization, A fair globalisation: Creating opportunities for all, argues for all organisations in the multilateral system to deal with international economic and labour policies in a more integrated and consistent way as a foundation for economic development and social justice.

The report, which the international trade union movement has hailed as a major breakthrough, calls for a globalisation policy forum to be set up by international organisations (such as the IMF, the World Bank, the ILO, the WTO and the OECD) to achieve a fairer form of globalisation, and which would address and monitor the social impact of developments and policies in the global economy. This forum must bring about cohesion between the international institutions on social issues.

To tackle a particularly egregious aspect of globalisation, the World Commission report calls for better conditions for workers in Export Processing Zones (EPZs). These zones, which according to the World Commission employ in excess of 50 million workers worldwide in countries as varied as the Dominican Republic and the Philippines, are often a hotbed of anti-union activity. Fundamental trade union rights are denied to workers, most of whom are women, as the zones are often beyond the reach of national labour laws which may themselves be weak.

Policy coherence initiatives between relevant international organisations should be established, according to the World Commission, to tackle just such

\section{Workers' UNion}

Every year, over 2.2 million workers die in over 270 million occupational accidents, or from 160 million new cases of reported occupational diseases. Many more are injured or incapacitated because of their work. To remember those workers who are killed, injured or become ill due to "unsustainable forms of production", representatives of the Trade Union Advisory Committee to the OECD (TUAC) are campaigning at the United Nations for decent work, better forms of worker protection, and participation in workplace decision-making.

At the time of writing, TUAC reported that ceremonies were due to be held in thousands of workplaces and public venues around the world - 10,000 in ltaly alone - and millions of workers were expected to observe the 28 April International Day of Commemoration. TUAC notes that this activity coincides with the official opening of the high-level segment of the UN Commission on Sustainable Development (CSD) session in New York, in which government ministers and other high-ranking officials will review the implementation of agreements from the 2002 World Summit on Sustainable Development. Trade unionists were expected to brief representatives of the CSD meeting in New York at the time, to bring them up to date on the actions taking place around the world and to confirm their resolve

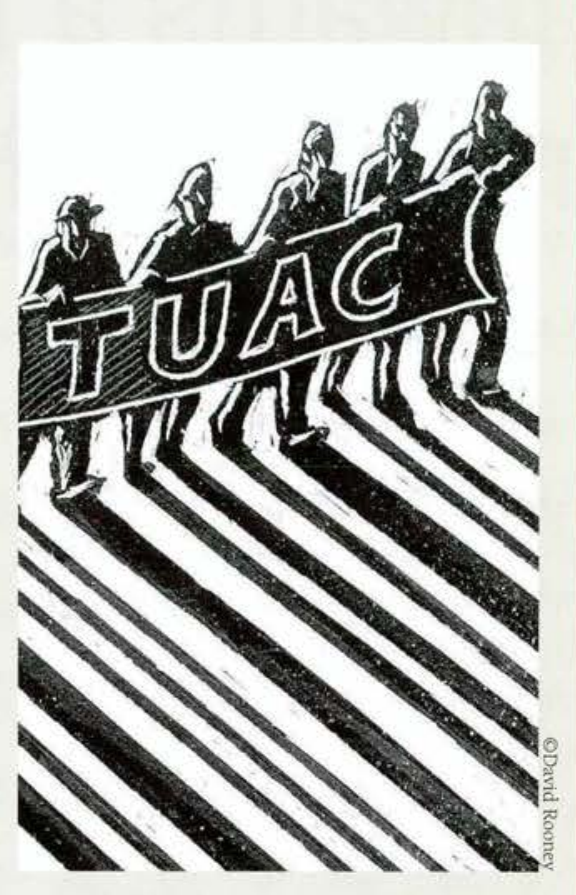

to work towards more sustainable workplaces, TUAC said. A summary of the 28 April events can be found at:

http:/www.icftu.org/displaydocument.asp? Index=991219085Language $=\mathrm{EN}$
The World Commission report further underlines the essential role of collective bargaining in promoting productivity and higher living standards, ensuring equality and giving workers a voice at the workplace. However, to achieve that function, it is key that the role of trade unions be supported by international organisations of real influence. The report targets the responsibilities of the international institutions and stresses the role they must play in ensuring that fair labour standards are not undermined.

\section{In Export Processing Zones (EPZs) fundamental union rights are denied to workers, most of whom are women.}

by-products of the processes of globalisation. Here, there is a clear role for the OECD in view of its established expertise in this area, as manifested in its current project to examine the impact of trade-related structural adjustment.
Altogether, the implementation of the many recommendations of the World Commission would go a long way towards developing a more inclusive form of globalisation, one that might stand a chance of tackling poverty and falling living standards, and help make a move towards the realisation of the MDGs.

This will require that significant international meetings this year, such as the OECD Ministerial Council in May and the G8 Summit in June, give the report their full backing and start examining how to implement its findings. The OECD Forum 2004 needs to give those imminent meetings a clear indication of the level of support that the World Commission's report enjoys among the OECD's constituencies and, indeed, the public at large.

References

- ILO (2004), A fair globalization: Creating opportunities for all, Report of the World Commission on the Social Dimension of Globalization, Geneva: www.ilo.org/publiclenglish/wcsdg/

- For information on OECD Forum 2004: www.oecd.org/forum 2004

- For further information on the OECD's work on trade-related structural adjustment: www.oecd.org/trade 


\section{False economies A global health crisis}

Brett Parris, World Vision Australia and Department of Econometrics \& Business Statistics, Monash University

In an age obsessed with economic efficiency and tax cuts, it is ironic that by allowing health systems in developing countries to deteriorate, the industrialised world is engaged in one of the most dangerous experiments in false economy in history.

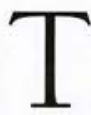
he UN Millennium Development Goals, particularly those to reduce under-5 and maternal mortality and to halt the spread of HIV/AIDS, malaria and tuberculosis, are far from being reached.

HIV/AIDS killed some 3 million people in 2003. Around 40 million are infected, including 2.5 million children, and each year there are some 5 million new infections.

Tuberculosis is in a similar league. One third of the world's population is infected. In 2002, there were 8.8 million new cases, and around 2 million deaths from TB. There are cures, yet only around $37 \%$ of TB cases receive proper treatment, due to a lack of resources and unreliable supplies of quality drugs. As a result, multi-drug-resistant TB (MDR-TB) incidence is surging, with 300,000 new cases each year. MDR-TB is a hundred times more expensive to treat than normal TB.

Another major killer is malaria - and as with $\mathrm{TB}$, drug resistance is a growing

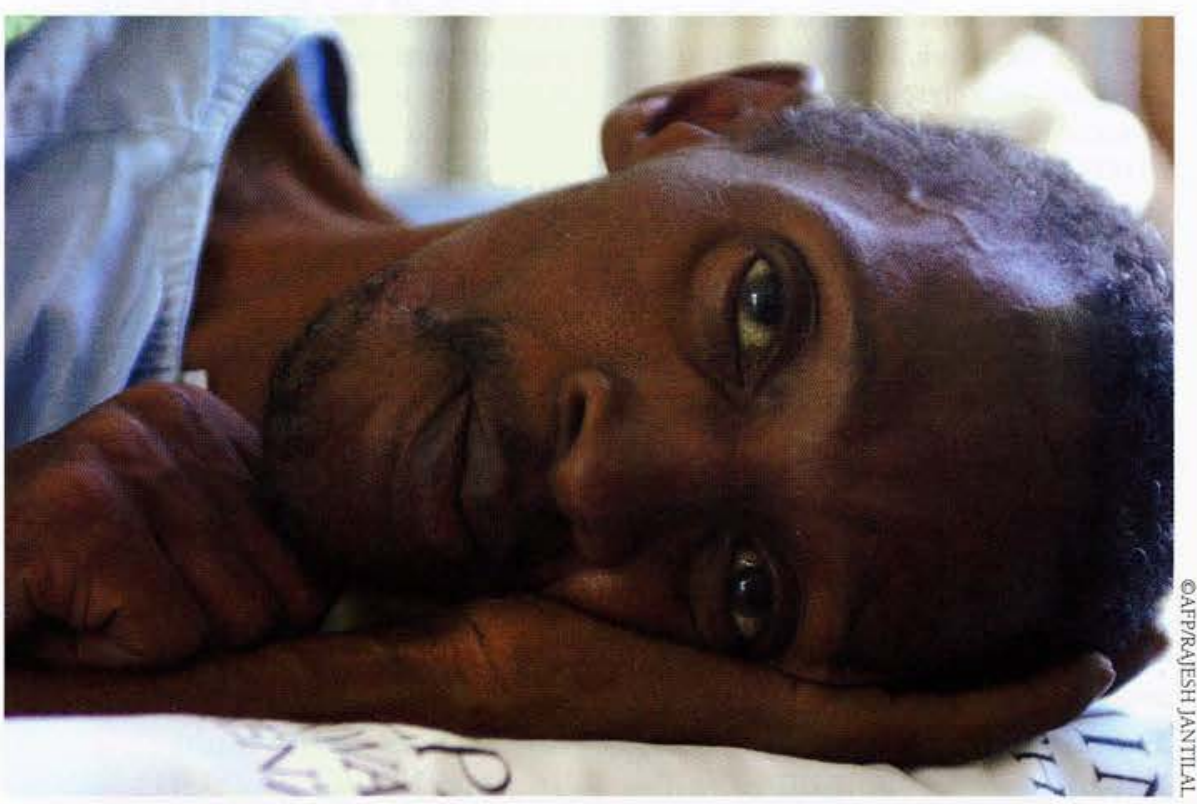

problem. Each year there are 300-500 million cases, with 1-3 million deaths - mostly children. The social and economic burden of such endemic infection is catastrophic. Economists have estimated that sub-Saharan Africa's GDP in 2000 would have been US\$400 billion rather than $\$ 300$ billion if malaria had been eliminated in 1965. Instead, malaria continues to undercut sub-Saharan Africa's GDP per capita growth rates by some 1.3 percentage points per year.

These are just three major diseases. There are many others, caused by poor access to clean water, inadequate sanitation and malnutrition. Over a billion people still do not have access to clean water and 2.4 billion have inadequate sanitation.

Disease and poverty cannot be allowed to win like this. Without a literate and healthy workforce, poor countries have little hope of sustained economic and social development. Malnutrition and illness in childhood can stunt both physical and intellectual growth. We all agree that education is fundamental, but sick and hungry children are often unable to attend school, and cannot learn well. As a result, many countries are finding themselves with large pools of poorly educated, unemployed and alienated young people. This is hardly a recipe for fostering the political stability, social cohesion and investment climate necessary for development.

The 2003 WHO World Health Report emphasises the urgency of rebuilding developing country health systems, but this cannot be done without a substantial increase in resources. At a time when new pledges are being made to boost aid (see article by Richard Manning, p. 36), we need concerted action on some focused areas if we are to stave off this global public health disaster.

1 More aid to health: The money available for combating global epidemics and collapsing health systems remains meagre. For example, the total funds allocated to TB control in socalled High Burden Countries were a mere 
$\$ 884$ million in 2002. Since its inception in January 2002, the Global Fund to fight AIDS, Tuberculosis and Malaria (GFATM) has received pledges of only $\$ 5.4$ billion through to 2008 of the $\$ 10$ billion requested.

This is a false saving and you do not have to look to poor countries to understand why. Take New York. Following cuts to TB control measures in the late 1970 s, a TB epidemic flourished, resulting in 20,000 more cases between 1979 and 1994 than would have occurred without the cuts. Around $20 \%$ of patients were infected with MDR-TB, which pushed the total costs of the epidemic to well over \$1 billion. Stopping the epidemic was a public health triumph, but it took 20 years to get infection rates back below their 1980 level.

Russia faces a far bigger challenge. It has been estimated that of Russia's one million prisoners, around 100,000 have infectious $\mathrm{TB}$ and up to 30,000 of those have levels of infant mortality, lower levels of immunisation against measles and diphtheria, pertussis (whooping cough) and tetanus (DPT), lower female life expectancy and higher levels of female illiteracy among both youths and adults. It also matters what types of products countries export. Higher proportions of goods exported are generally associated with better poverty indicators. A more comprehensive, long-term approach to trade policy is required than one of simple liberalisation. Developing countries must be given the resources and policy space to develop their capacities to diversify their export bases appropriately.

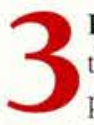
Reverse the "brain-drain": One of the greatest constraints in scaling up public health efforts in the poorest countries is the lack of trained staff. Yet far from supporting developing countries' health systems, some industrialised countries are actively undermining them by recruiting health workers for their own systems, which they have systematically

\section{Economists estimate that sub-Saharan Africa's GDP would have been US $\$ 400$ billion rather than $\$ 300$ billion if malaria had been eliminated.}

MDR-TB. Each year 300,000 prisoners are freed, around 30,000 of whom have infectious TB - and of these, 10,000 have MDR-TB. The OECD countries should not delude themselves into thinking they will be unaffected.

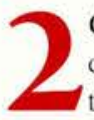
Greater market access: Developing countries have a legitimate grievance that, despite declining terms of trade for primary commodities, they are still denied fair access to rich country markets, and are undercut in export markets by massive EU and US agricultural subsidies. It is a scandal that around six times more is spent subsidising agriculture in OECD countries than is given in aid.

Just as important as market access, however, is how reliant a country is on a narrow range of exports. A recent World Vision report, Risky Development, found that such export concentration is associated with increased terms of trade volatility, higher under funded. For example, between a third and a half of South African medical graduates emigrate. A multilateral solution based on ethical recruitment protocols and compensation for countries losing skilled personnel is urgently needed. The UK government's 2001 Code of Practice for the international recruitment of healthcare professionals strongly condemns recruiting in developing countries except under strict conditions. This is encouraging, but a longterm solution must be based on creating incentives for local staff to stay. Again, this requires resources, which many countries simply do not have.

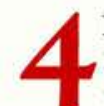
Better drugs and vaccines: Between 1975 and 1997, only 13 of the 1,223 new medicines commercialised were for tropical diseases and there has been no new class of TB drugs produced since 1966. Diseases of poor countries do not generally incite pharmaceutical companies to develop new drugs. But incentives could be created, by having bodies such as GFATM make pre-commitments to purchase newly developed medicines and vaccines.

5 Relax conditionality: Seriously AIDS-affected countries, particularly in Africa, must be treated as special cases, with more relaxed conditionality frameworks for their World Bank/IMF loans. This would enable their governments to focus more effectively on the fight against AIDS.

Failing to respond to the global health funding crisis will cost OECD countries dearly. It will postpone the day when poor countries will be rich enough to form vibrant new export markets; it will boost the flow of asylum seekers; it will require expensive interventions in failed states; and it will allow potentially catastrophic multidrug-resistant diseases to ferment largely unchecked.

How much would it cost to seriously address these problems? The chair of the WHO's Commission on Macroeconomics and Health, Jeffrey Sachs, reported that it would require an extra $\$ 25$ billion annually from the rich countries. That's about one thousandth of their annual income; ten cents in every hundred dollars.

False economy, indeed. How's that tax cut looking now?

References

- A fully referenced version of this article is available from the author at: brett_parris@wvi.org

- Currah, K. \& Whaites, A. (Eds) (2003), False Economies: Why AIDS-Affected Countries are a Special Case for Action, World Vision International, Geneva.

- Gallup, J.L. and Sachs, J.D. (2001), "The Economic Burden of Malaria", American Journal of Tropical Medicine and Hygiene, Vol. 64 , No. $(1,2) \mathrm{S}$

- Parris, B.W. (2003), Risky Development: Export Concentration, Foreign Investment and Policy Conditionality, World Vision International, Geneva.

- Reichman, L.B. and Tanne, J.H. (2002), Timebomb: The Global Epidemic of Multi-DrugResistant Tuberculosis, McGraw Hill, New York

- Sachs, J.D. (2003), "Achieving the Millennium Development Goals: Health in the Developing World", speech at the Second Global Consultation of the Commission on Macroeconomics and Health, Geneva, 29 October. 


\section{Why do some countries do better than others?}

\section{Do aid agencies make a difference?}

\section{The MDG challenge: \\ Can partnerships provide the answers?}

UNDP's Development Effectiveness Report 2003 puts performance under the spotlight by examining the notion of development effectiveness. It covers two components: The first deals with country performance, looking at the evidence and assessing UNDP's own contribution-thus linking organisational performance to development effectiveness. The second part tackles global concerns and the role of donor countries in development effectiveness. It focuses on the need for stronger partnerships between developed and developing countries and presents strategies for meeting the Millenium Development Goals.

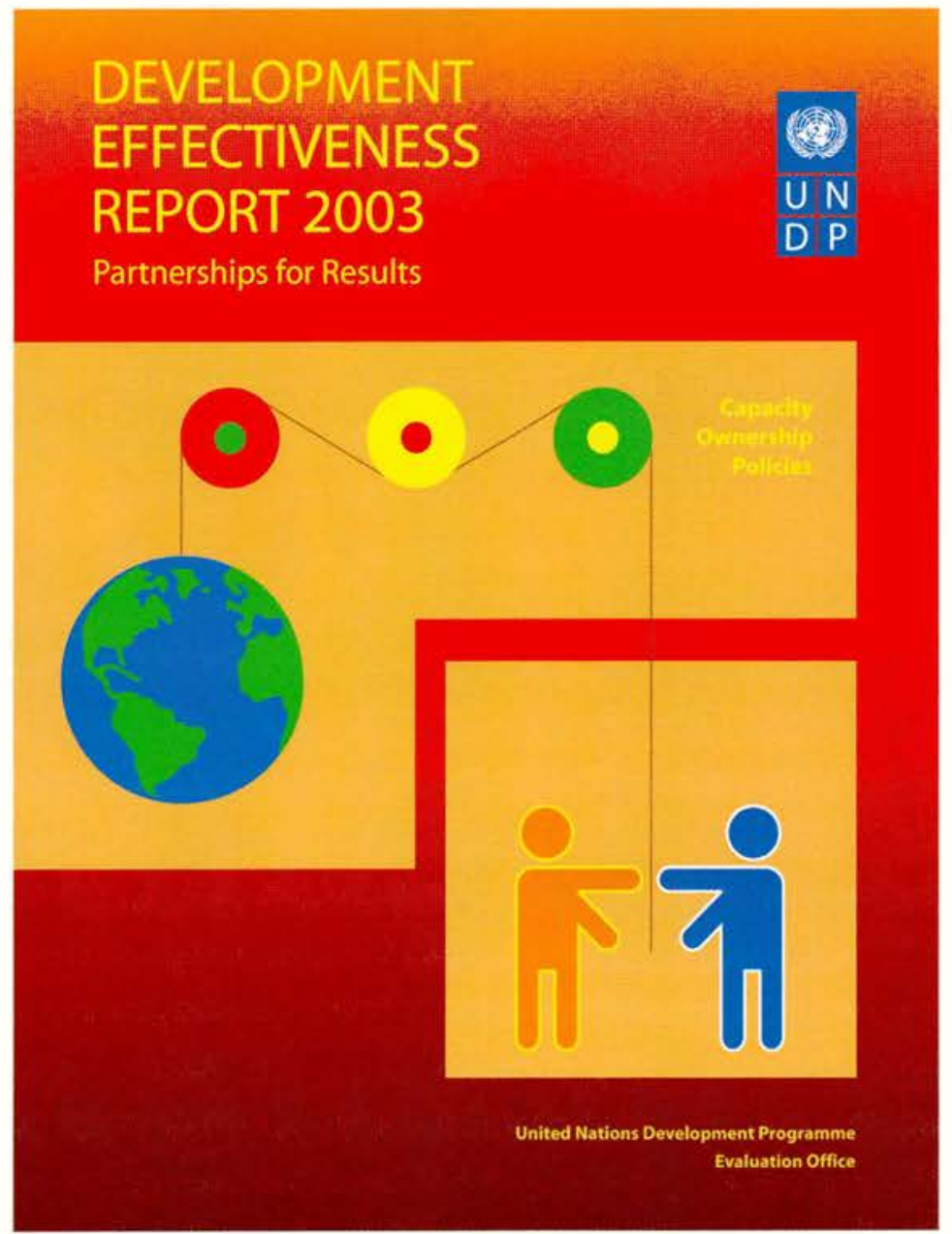

Copies of the DER are available at the Evaluation Office, UNDP, 1 UN Plaza, Room 460, New York, NY 10017. The electronic version is available at www.undp.org/eo/ 


\section{Migration and EU enlargement}

OECD Directorate for Employment, Labour and Social Affairs

The adhesion of 10 new members to the $\mathrm{EU}$ is good news for business. After all, with 25 instead of 15 countries, it ushers in an even bigger market for goods and services, capital and labour to move about in. Well, perhaps not quite yet.

$\mathrm{O}$ ne of the great dreams of European integration since the Treaty of Rome has been to create a completely unified labour market, though this has proven hard to achieve in reality. Even among the present EU 15, while free movement of persons and labour market access for workers is possible, obstacles continue to exist, like recognition of qualifications and access to social welfare benefits.

In addition, there are obvious language barriers which slow down mobility, as well as the reduction of wage differentials between immigrants and nationals. In most cases, workers from Poland or Hungary or any of the other new members will not be free to seek work in another EU country under normal conditions for several years.

This is because a majority of member states have introduced transition periods ranging from two to seven years, in order to stem a possible increased inflow of new migrants from eastern Europe and the pressures this would entail. Some countries, such as Ireland, Sweden and the United Kingdom, will not be imposing transitional arrangements, while the Netherlands and Portugal will impose a quota. Is their prudence worth it? Would immigration from new accession members suddenly rise if a transition phase were not introduced?
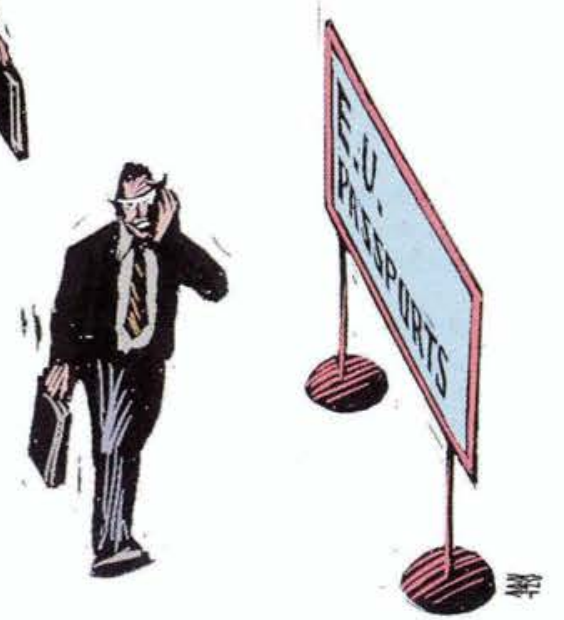
Not necessarily. In the past, immigrants into European countries, except for Germany and Austria, came predominantly from countries outside Europe, from Asia and North Africa, for instance. Flows from eastern Europe also concern non-European OECD countries, for example, Poles and Hungarians to the United States, Canada and Australia. For historical reasons, countries have received immigrants of different origins. Moroccans and Algerians are common in France, Turks and former Yugoslavians in Germany and the Netherlands, and Pakistanis and Indians in the UK, to cite some well-known examples. During other periods of EU enlargement to include Greece (1981), and Spain and Portugal (1986), migration did not rise. In the case of Spain, return migration had occurred before accession. The bulk of immigration from southern Europe occurred mainly and massively during the 1950s and 1960s. These migrants built communities that then acted as a draw on new immigrants. The links between $\mathrm{EU}$ accession countries and existing EU member states are probably more diffuse. Flows from the east might grow in importance, but probably not from the accession countries; other countries such as Romania, Moldavia and the Ukraine may be more important sources.

The renewed interest in labour-related migration in many OECD countries in the last decade, as well as the predominance of family reunification and the great number of asylum seekers, counters criticism of what is termed "Fortress Europe". As our chart shows, the number of immigrants, including from outside

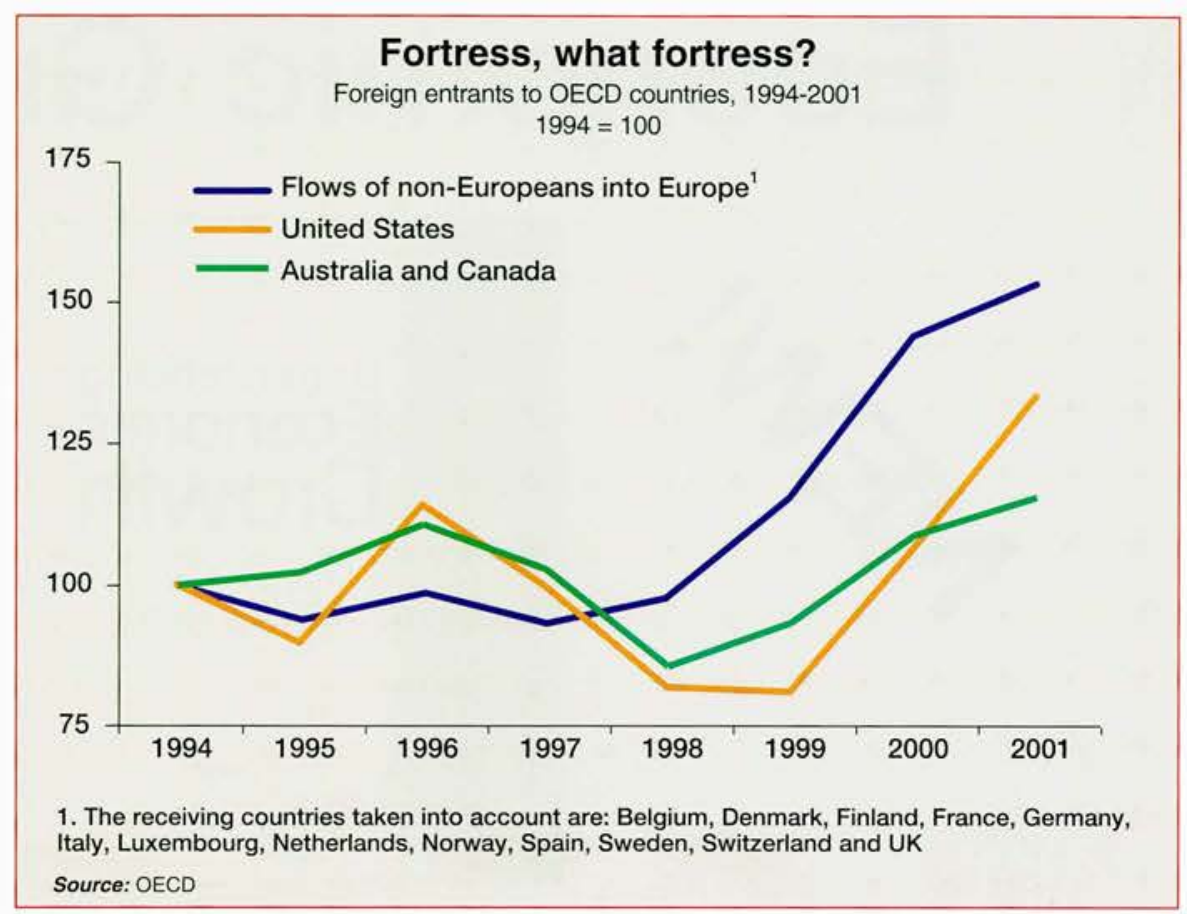

Educational costs are high also, especially in cases of accompanying dependents or family reunification.

One of the most hotly debated questions is whether a large increase in immigration flows would help OECD countries pay for their future social spending, especially on pensions. The argument is that more young immigrants mean more young workers and so more revenue for social services and pension funds. In this hypothesis, the focus is mainly on employing high-skilled immigrants who will come for a temporary

\section{A majority of member states have introduced transition periods to stem a possible increased inflow of new migrants from eastern Europe.}

the EU, has risen far more sharply in Europe over the last decade than in the United States.

One reason for policy prudence towards foreign workers is that immigration can raise social costs, in education and healthcare, for instance. But can migrants alleviate these costs, too? The immediate costs are in healthcare and social protection, especially for humanitarian immigration. period rather than on recruiting more lowskilled workers. However, this thinking has its flaws. The most obvious is that immigrants are frequently not temporary and may wish to settle and retire in the host country themselves. And their population is ageing too, to become tomorrow's pensioners. Furthermore, not all legal immigrants join the workforce. In Australia and Canada, countries which operate selective immigration policies based on labour market needs, only a quarter to a third of annual entrants are active workers; the rest being family dependents, including school-age children.

Another limit is whether the immigrants actually find work. The unemployment rate among foreigners in some European OECD countries is twice that of their percentage in the total labour force. Those who do find work are often paid less than native workers. Indeed, some OECD countries have begun focusing more energy and finance on training and supporting new arrivals, in part to help them to integrate more rapidly into the labour market or to retain those who might otherwise move on to competitor countries. But while such policies can help integrate foreign populations and overcome certain labour shortages, immigration alone cannot generate sufficient funds required to finance the increasing demands of ageing populations.

References

- OECD (2003), Trends in International Migration, Paris.

- OECD (2001), Migration Policies and EU Enlargement, Paris

- See: www.oecd.org/migration/ 


\section{Understanding \\ Economic Growth}
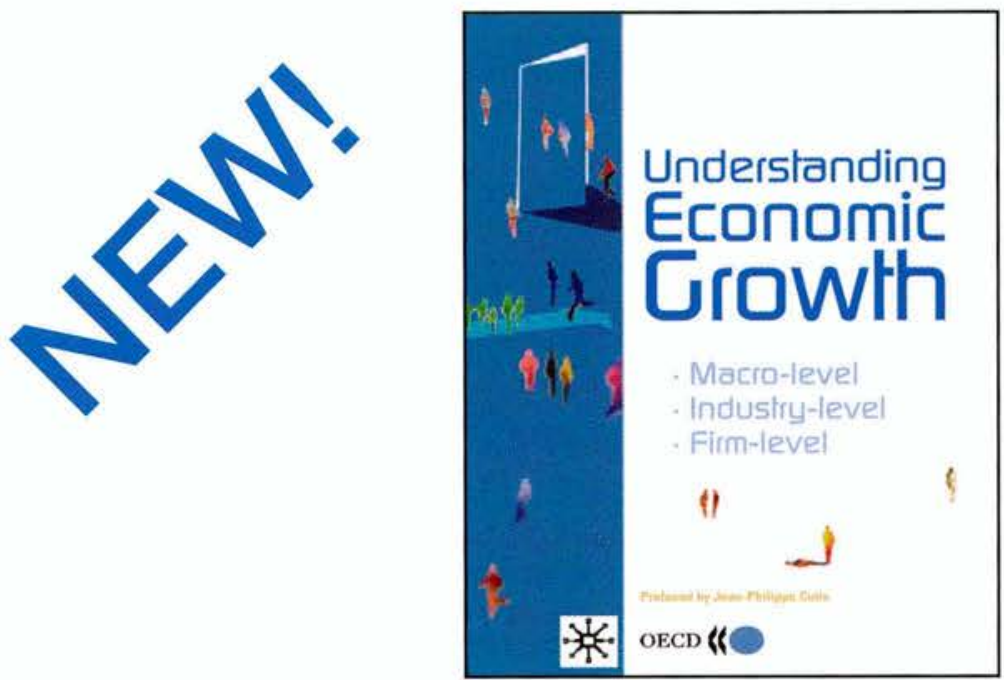

- Analysis of growth patterns of OECD countries

- Identifies the fundamental drivers of economic growth

- Examines growth at the macro-economic level, industry level and firm level

- Packed with over 50 tables and figures

"Get unique data to better understand the reality of economic growth.

In 2000, at the height of the new economy, IT was hailed as a technology that would radically transform OECD economies and bring large economic benefits. But the recent economic slowdown has laid to rest several of the myths surrounding IT. What is the real contribution of IT or economic growth?"

Understanding Economic Growth provides a comprehensive overview of these issues and new insights into economic growth.

Available at: Palgrave Macmillan, Orders, Houndsmills, Basingstoke RG21 6XS, United Kingdom

Telephone: +44 (0) 1256302866 Fax: +44 (0) 1256330688 Email: orders@palgrave.com Web: www.palgrave.com (ISBN: 1403941475) 


\title{
Why change is so difficult
}

\section{Some reflections on the political economy of reform}

\author{
Val Koromzay, Director for Country Studies, OECD Economics Department*
}

\begin{abstract}
Why is broad-based economic reform so difficult? And, even more fundamentally, what is economic reform anyway? A clear understanding of the problem offers the best hope of doing better in the future.
\end{abstract}

$\mathrm{T}$ he fact that broad-ranging, fundamental economic reform is difficult is attested to by the simple observation that it is quite rare. Much of what one observes in the economic history of OECD looks more like "coping" - often belatedly - with problems; or taking one step forward and one step back. I argue that significant reform requires a confluence of two factors that do not often come together: a broad-based popular sentiment that "things have to change", and a leadership that is able to translate this broad dissatisfaction into a concrete programme that crystallises the issues and points to their solution. Most of the time, democratic politics turns out to be quite conservative. Mandates for real change are rarely extended to governments.

To see why this is so, it is necessary to figure out what economic reform actually is. How can you spot a true economic reform, as opposed to an arbitrary change in policy? I am not aware of any agreed answer to this question, and the one I offer is no doubt incomplete: the best definition I can come up with is that economic reform is policy change directed at improving the static or dynamic efficiency of resource allocation in the economy. But, at its essence, this involves taking away rents that have built up in the economic system or, to broaden the concept somewhat, to reduce or modify acquired rights. Of course any political programme might involve a redistribution of rents - in favour of those who support the government, perhaps at the cost of those who do not. So reform, as opposed to redistribution, involves reducing rents in the economy as a whole - including rents that accrue to the "natural constituencies" of the party in power.

A few examples can serve to clarify the point.

A strengthening of competition policy, broadly defined, is perhaps the most obvious example. Such a move is generally accepted to improve market functioning, but the immediate target is the rents that accrue to companies with market power, and probably also for the workers who share in these rents. It is thus not only the capitalists, but also the workers who are likely to feel threatened.

Likewise, a tax reform to broaden bases and lower rates is clearly an efficiency-improving move. But tax distortions create rents in favour of those who are in a position to exploit them, and it is these rents that are targeted by the reform. The more outrageous the tax loophole, the greater the likelihood that someone is vitally dependent on it for survival.

Perhaps the most provocative economic reform issue to try to fit into this "rent reduction" framework concerns social policy. On the face of it, it would be antediluvian on my part to argue that social benefits - social assistance, extended unemployment benefits, housing benefits, child allowances, etc. - that most of our societies provide to cushion the impact of adverse fortune
Broad-based reform seems to require, as a necessary condition, a perception of crisis. 


\section{Reform involves reducing rents in the economy as a whole - including rents that accrue to the "natural constituencies" of the party in power.}

on those least able to cope with it, constitute "rents". Politically, most OECD countries have opted to enshrine such redistribution as basic rights for the population, and in most countries there is at least acceptance that such redistribution is part of the fundamental social contract. Furthermore, even on narrower efficiency considerations, there is substantial evidence of dynamic positive spill-overs from adequate social support to overall economic performance - in particular as regards the safeguarding of economic opportunity for children.

Nonetheless, it has to be recognised that social policy involves a double burden: on society at large via higher (and thus inevitably more distorting) taxes; and also on the supply-side, by creating rent-seeking opportunities for potential beneficiaries - a phenomenon summed-up in the economists' jargon of "poverty traps" and "unemployment traps". The solutions here are complex, but most economic reform programmes have recognised the importance of transforming unqualified "rights" to social benefits into a much more conditional "contract" between donors and recipients based on one form or other of mutual obligation and - in the end - only a contingent right. Reform of disability pension schemes is perhaps the most visible current example.

If reducing rents in the interest of greater efficiency is a task that can be counted on to evoke the opposition of those whose rents are at risk, it would be hard enough. But the problem goes deeper, because of the general tendency for rents to be capitalised out of the economic system.

Housing subsidies, for instance. When introduced (perhaps for apparently compelling social reasons), such subsidies constitute a rent to those who can now afford more housing than otherwise. But over time, the subsidy gets built into the price of houses. This is a capital gain to those who happen to own a house, but for new entrants into the market there is really no benefit. The value of the subsidy is just offset by the higher price they have to pay for the house. The point is, while it might make sense to scrap the subsidy, it is very difficult to do because the current crop of house owners (assuming the subsidy has been around for a while) did not benefit from the subsidy, but do bear the cost if the subsidy is stopped. This could be seen - with considerable justice - as a very unfair policy.

Agricultural subsidies are very similar. Their value is capitalised in the value of land; but it is extremely difficult to know who has actually benefited. Current farmers are not the most likely beneficiaries; but they are the ones likely to be wiped out if the subsidy is halted.

A final somewhat more complex illustration is provided by the difficulty of reforming pay-go pension systems. Following the Samuelson consumption-loan model, the initial generation essentially gets a free ride. The one-time gain in going from a system where you provide for your own pension to one where your kids provide it for you is capitalised out of the system. But then, even under stable demographics, future generations earn a much lower return on their contributions than their parents did; and in an ageing society this return becomes small or even negative. In these conditions a funded system would look far more attractive, but to achieve it requires putting back the capital that was taken out by the first generation of this example - a burden on the "transition generation" that most societies are not prepared to face.

So, to summarise the argument, economic reform is about reducing rents. It will be opposed by those whose rents are at risk - and they know who they are. The beneficiaries from the efficiency gains brought about by reform are much less aware of the benefits, which in any case tend to be dynamic rather than static. Thus, if competition policy or regulatory reform creates new market opportunities, one can predict that these opportunities will be exploited; but one cannot identify ex ante who it is that will exploit them (they may not know themselves at the time of the reform!). On top of that, in many cases the rent reductions that are the consequence of the reform may be seen, and indeed felt, as unfair in that it is not the beneficiaries of the rent who bear the cost of its reduction. It is, in my view, this nexus that makes reform so difficult.

In view of this difficulty, it is perhaps amazing that reform nonetheless happens. The upshot is, that with very few exceptions, broad-based reform seems to require, as a necessary condition, a perception of crisis - acute crisis as in the case of Scandinavia at the start of the 1990s; or at least a sense of chronic deterioration, as in New Zealand prior to the 1980 s reform and in the Netherlands in the mid-1980s, or the United Kingdom under Thatcher. The hallmark of such crisis situation not surprisingly if you think about it - is an outof-control budget. I guess the point is that real reform only becomes possible once the possibilities of throwing money at a problem are foreclosed. 
One supposes that crisis conditions may also, in the end, prove a sufficient condition for reform, at least in mature democracies where one imagines that good sense will prevail in the end. But it is clear that the timing of reform depends on political leadership - in the first instance leadership to make clear that there is a crisis. The last decade in Japan following the collapse of the bubble economy, indicates how - even when international observers have no difficulty in identifying crisis conditions, popular perception may not coalesce into something solid enough to permit a fundamental departure from "politics as usual", forcing the government to move cautiously and step-by-step for a very long time.

I recognise that this presentation seems to have led me into a somewhat nihilistic corner, to the point of saying that the most realistic reform scenario is to wait for things to get so bad that there is no other option. I have to confess that, as regards "core Europe", my sense is that in this sense the pre-conditions for fundamental reform have not yet been met. But this should not imply passivity. Surely there is much that governments can do to promote reform even when lacking a clear mandate for wideranging action: to move ahead in areas where the ground for reform has been best prepared; and to lay the groundwork for further reform by setting out to shape, or reshape, popular understanding of the issues. Various techniques - advisory "expert" commissions, budget sustainability exercises, even tripartite consultations (if not allowed to become a kind of second government outside electoral validation) can play a very useful role. And indeed, in this domain, effective international support for reform via institutions such as the EU or the OECD can play a significant supporting - or indeed at times initiating - role.

\footnotetext{
The views expressed in this note are strictly the personal reflections of the author, based on his own experience of "watching" economic developments in the OECD over a quarter of a century, and do not necessarily reflect the views of the $O E C D$ or its member governments.
}

The article is extracted from comments presented to the international conference on Economic Reforms for Europe: Growth Opportunities in an Enlarged European Union. Bratislava, Slovakia, 18 March 2004.

\section{French resistance}

\author{
Christine Clerc
}

France has sometimes been described as an "unreformable country in need of reform". The OECD's own studies see much room for improvement in the French economy, in areas like the labour market and large industry, while inefficiencies and bottlenecks have dampened French growth potential in recent years. But for acclaimed French journalist, Christine Clerc, while her country certainly has grave problems, these should not be allowed to blind us to the positives. Ms Clerc recently wrote a new book, Le bonheur d'être français, "as a response to those who have been banging on about France's decline over the last few years." She explains.
$\mathrm{T}$ hough I am a political rather than economic journalist, I grapple with economic realities in my work. Frankly, I find it hard to trust the experts - even those at the OECD! (Maybe my scepticism is typically French, but I'll get to that in a minute.) I don't believe our experts take everything into account when discussing France's future, particularly the high quality of life, our overall skills and abilities, the excellence of our roads, trains and public services. We do pretty well on this score, compared with our British neighbours for instance. Indeed, only recently company chiefs across the Channel have been complaining aloud that their poor infrastructure is hurting their competitiveness.

Furthermore, I think some experts are trapped by a certain ideology. In any case, they sometimes get it wrong. Take Eurostat, the EU's statistics office. In 2002, they

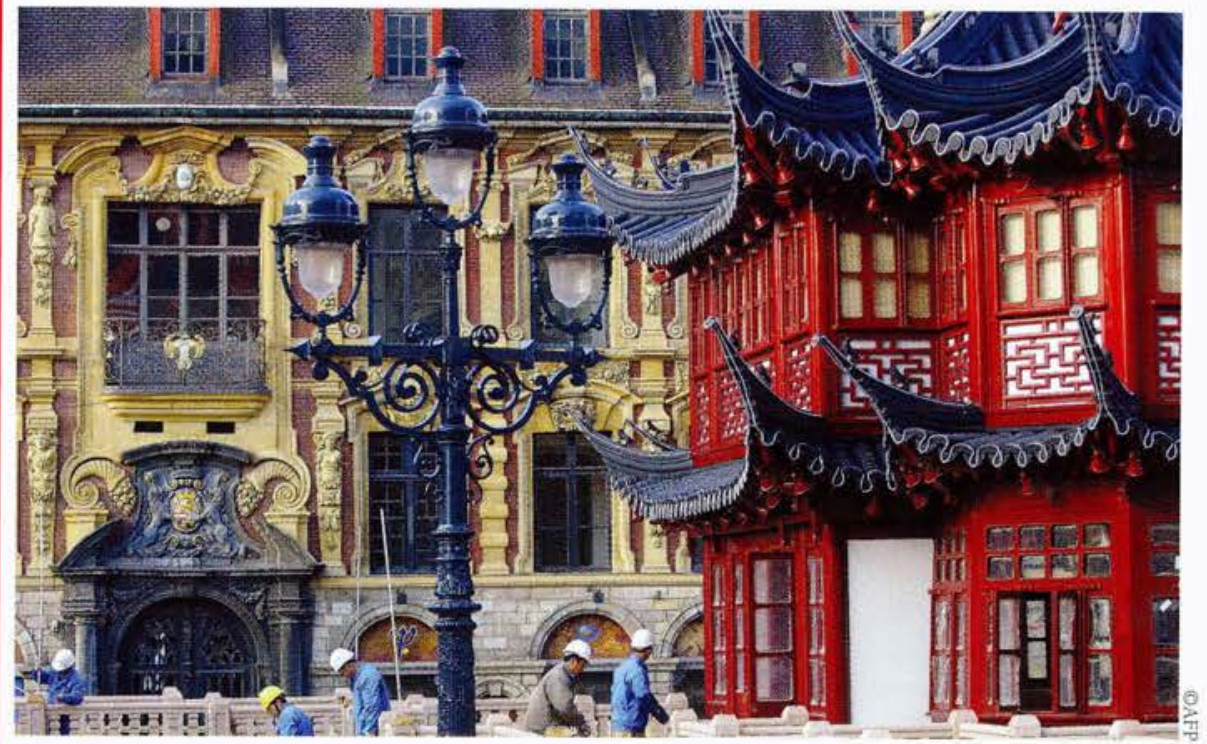

Nouveau Nord: China in France, Lille 2004 
sparked the debate on France's decline by publishing figures that showed our GDP was ranked only 12 th in Europe. Two years later, they announced (very quietly) that they had miscalculated the data: instead France was much higher, around 5 th place. This is perhaps not as brilliant a performance as it might be, but it is not that bad.

To be sure, France has serious problems to deal with. There is no denying the alarming size of our public debt and deficits. And nor can we ignore "the French disease": an unemployment rate stuck above $10 \%$.

Yet there is hope: for a small country of only 60 million people, France still has remarkable assets. And we are still capable of great things, whether alone or, increasingly, with our European partners, in aviation, energy, engineering and medicine, etc. France, like its neighbours, has shown itself to be quite capable of overcoming difficult crises. This is the message I tell my fellow countrymen and women in my book.

Start with the Nord Pas de Calais area, which was hit on three fronts some 20 years ago by cutbacks in steel, coal and textiles. It was a dark region then, with its slag heaps, its smoking piles of waste, its rusty furnaces, abandoned factories of blackened brick. But today it is a flourishing,
Lorraine is another region where demand from Asia has prompted similar stories of revival, even in coke production! In fact, all over France I have met creative women and men taking advantage of opportunities like this, and in all walks of life.

With such prospects and resources, why should anyone feel pessimistic? Perhaps it is our character, this very French ability to put ourselves down. To us, this is even a form of intelligence. At the same time we cannot stand being criticised by the Americans or the British, or the Germans. As Cyrano de Bergerac put it, we can criticise ourselves, but damned if anyone else can.

Does this mix of arrogance and selfpunishment really make reforming France so difficult? Current events suggest so, but I would like to think the French are capable of making the sacrifices change demands, as we did before when de Gaulle's government introduced some pretty drastic reforms. As long as the situation is explained clearly, we will do it. The French want to hear the truth! This is the conclusion I draw in my book. The trouble is, I am not convinced the truth has been told that much since the petrol crisis of 1974 .

But what the French people really want is hope, including jobs for their children. We are living through difficult times and while

\section{We are still capable of great things, whether alone or, increasingly, with our European partners.}

cosmopolitan part of France, and attracts thousands of tourists to its abundant theme parks, museums and recreational areas while creating 55,000 jobs in the process! In this region as in others, globalisation has also wreaked some havoc, causing factories to up and leave. But globalisation has also brought in new markets. In Roubaix (part of the Lille conurbation), the legendary Lainière wool company, which in its hay day 25 years ago employed 15,000 people and even received a visit from the Queen of England, had disappeared. But five years ago it was reincarnated in the form of a "business incubator" housing about 50 small fabric producers selling fashionwear "Fabriqué en France" to the new wealthy of China. there are opportunities, ordinary people feel anxiety. About globalisation, even about the expansion of the European Union. Not that they fail to see the opportunities these developments offer, but they also see risks looming, affecting their jobs, their livelihoods. To my mind, this underlines our need to build Europe properly, according to our trusted values of social cohesion and solidarity. That means building a system that compensates for losses caused by relocating firms, for instance. The social rules of the game should be clearer and firmer. A wider EU will not work if it is created simply so that investors can head off and hunt out the cheapest labour available. This keeps us all down. Workers may well benefit from
European construction, but they should be able to help build it, and not just be asked to pay the price of achieving it.

Which brings me to that French disease again, and for me, the real problem: how can a country as attractive and well endowed as France put up with such high unemployment, indeed, one of the worst in Europe?

How last summer's heat wave could kill 15,000 people also bothers me, but not as much. In many ways the entire heat wave trauma was hyped up. Unemployment on the other hand leaves entire families in desperation. And it has been literally destroying French society for 20 years!

Employment has to be the most important challenge facing France today. Solving it probably means reforming government bureaucracy - including altering the 35-hour week which has had a very upsetting effect on France's usually very dynamic small enterprises. But above all, both schools and universities need an overhaul. Standards have to be raised, and we have to be much more demanding about that. That means rewarding good performances more than punishing bad ones. Here again, the French must be told the facts, as they really are.

Finally, let's not forget the very special role women play in France, and elsewhere. I have met and written about many women from all kinds of backgrounds: farming, factory workers, company bosses, teachers, nurses, cultural affairs officers, etc. They are brave, mobile, creative and hard-working people. Everything depends on them, whether it be maintaining our quality of life or transmitting the knowledge and values that form the basis of this Old, yet ever so young, Europe.

* The first volume of Christine Clerc's Le bonheur d'etre français ("The Joy of Being French": our translation) published in 1982 won the Prix Albert Londres.

Christine Clerc is an acclaimed French journalist and currently a columnist for the daily newspaper, Le Figaro. She wrote this especially for the OECD Observer. She is author of over a dozen other books, notably Le Journal intime de Jacques Chirac. The second volume of Le bonheur d'être français was published by Plon in March 2004. 

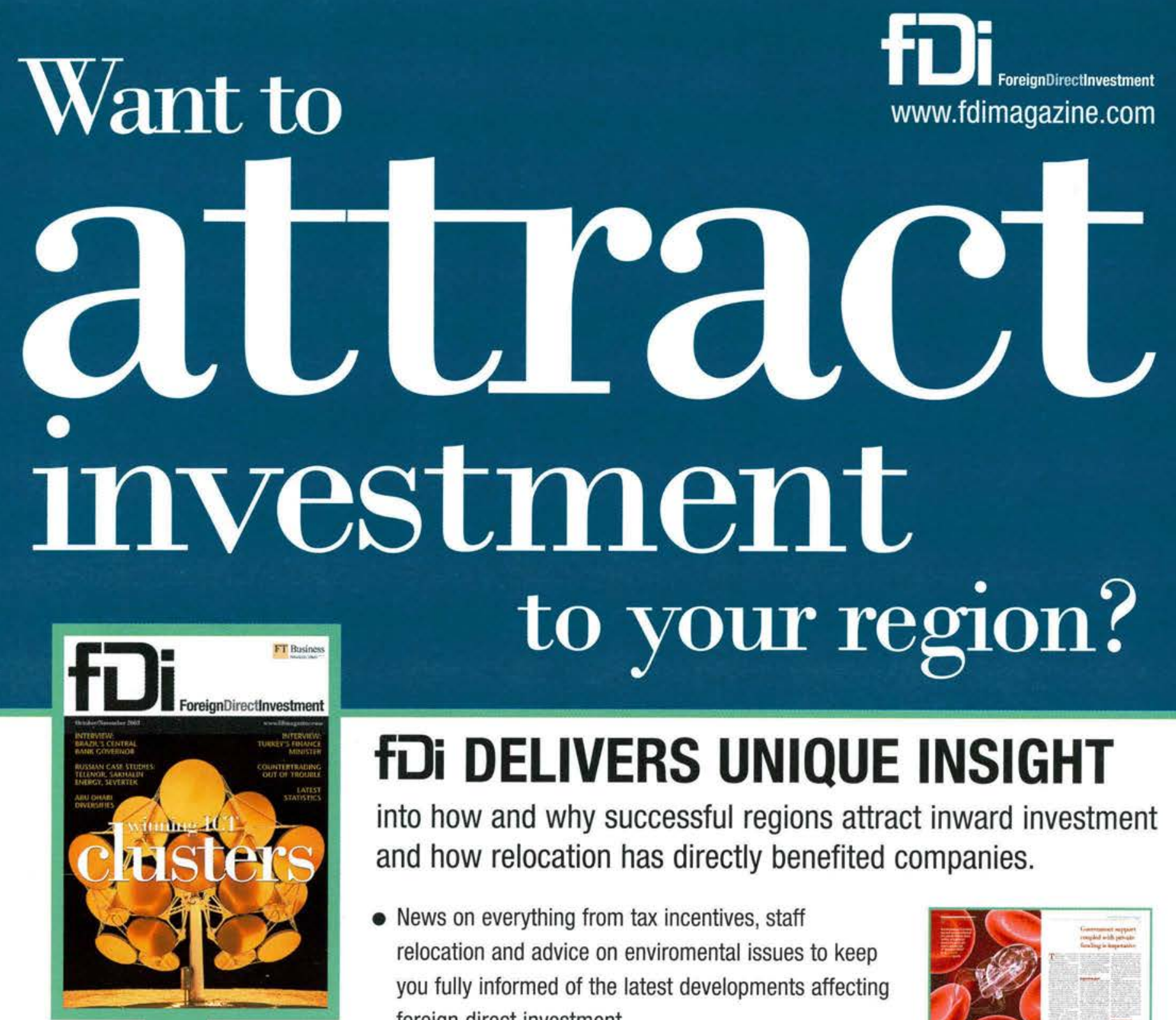

\section{fDi DELIVERS UNIQUE INSIGHT}

into how and why successful regions attract inward investment and how relocation has directly benefited companies.

- News on everything from tax incentives, staff relocation and advice on enviromental issues to keep you fully informed of the latest developments affecting foreign direct investment

- Cross examinations of the key players in the industry to help you gain insight into future strategies and imminent plans

- Profiles of new initiatives being used by other investment promotion agencies
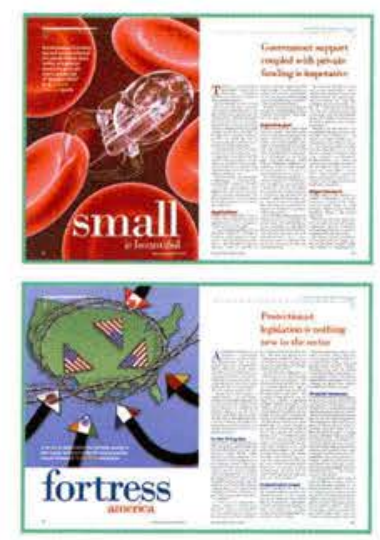

Circulation 14,751 (ABC certified 1 Jan - 30 June 2003)

Readership is Finance Directors, C-level Executives, HR Directors and other senior business individuals involved in making foreign direct investment decisions.

How to Subseribe

An annual subscription to fDi is $£ 95$ ( 6 issues). Subscribe today by calling customer services on +44 (0)20 86067545 quoting fd23042c. 


\title{
Development challenge
}

Richard Manning, Chair of the OECD's Development Assistance Committee

\author{
Aid is rising and major \\ reforms are under way. But \\ there is much more to be \\ done, in particular to reach \\ the Millennium \\ Development Goals, as \\ participants at this year's \\ High-Level Meeting of DAC* \\ agreed.
}

$\mathrm{O}$ ne of the oft-overlooked facts about the OECD is that its member countries handle over $90 \%$ of global bilateral development aid. The lion's share of foreign direct investment also comes from the $O E C D$ area. Add to this the fact that OECD members' trade, agriculture, intellectual property and environment policies, to name but a few, have huge impacts on people all over the world. Add as well the fact that, for over 40 years, aid ministers and heads of aid agencies have gathered under the auspices of the Development Assistance Committee (DAC), the principal body through which the OECD deals with development assistance, and a picture of the organisation as an important player in global development begins to emerge.

Development is one of those vital policy areas, like trade and the environment, where action is fundamental, yet difficult to achieve on the ground. But daunting as our

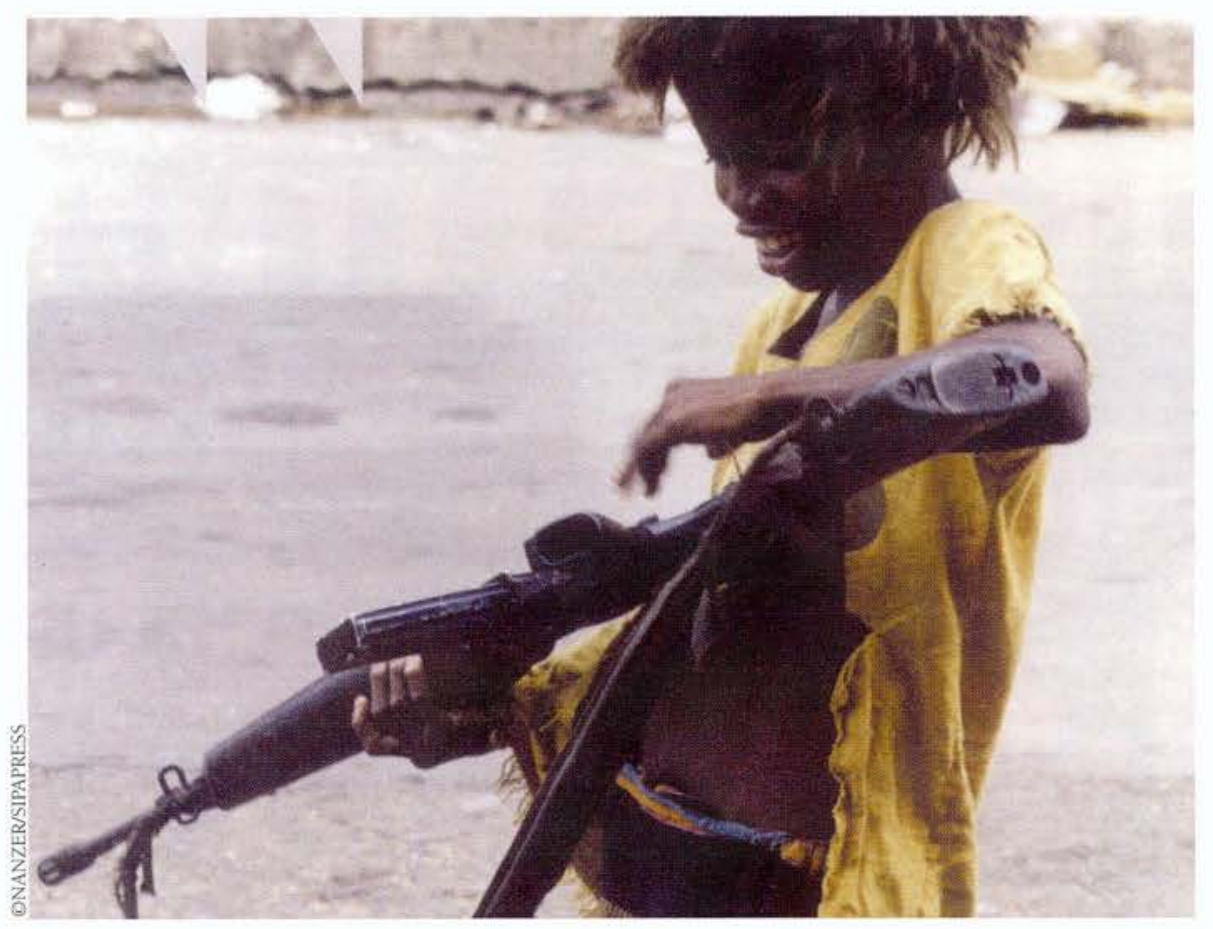

challenges are, there are signs of progress being made. We drew several significant conclusions at our High-Level Meeting, which took place this April.

The consensus reached and pledges made by most of our governments in Monterrey at the UN Financing for Development Summit in 2002 to boost our aid effort, remain the basis for decisions on aid budgets. We committed ourselves to honouring these pledges, while recognising that in spite of aid growth in 2002 and 2003, much more will be needed to tackle the Millennium Development Goals (MDGs) set for 2015 including reducing the percentage of people in poverty by half, cutting child and maternal mortality, and enrolling all girls and boys in school.

The increase in aid volume in 2003 was quite modest, although the rise of $11 \%$ in total over the last two years, after a decade of decline, takes total aid to a record level. While participants noted this increase, we underlined that much more will be needed to achieve the MDGs for 2015. Existing pledges imply a further rise in Official Development Assistance (ODA) of some $25 \%$ by 2006 . Encouraging as this is, there is no room for complacency.

Standing by the Monterrey pledges might seem the least to expect in view of the development goals, but it is nonetheless a significant achievement at a time of budget strain in many member countries. It will be important for parliaments and the public to understand and support major rises in allocations for aid. The high-level leadership demonstrated at Monterrey must continue. We also agreed to make greater efforts to ensure the public is better informed about the development objectives for which their taxes are being sought, the progress being made and the stakes involved. 
Historically high economic growth has lifted hundreds of millions out of poverty, particularly in Asia. Although growth rates of $5 \%$ per capita a year are occurring in some countries outside Asia, most have yet to generate the sustained growth needed to reduce poverty decisively.

Assistance to countries to support broadbased economic growth, as a basis for poverty reduction, can be improved. We examined the role of poverty reduction strategies and of aid in helping to boost growth rates. Trade is clearly important, and we stressed the need for progress on the Doha Development Round. We also recognised that aid for agriculture and infrastructure has been falling, yet most of the poor live in rural areas and poverty reduction requires a major increase in their productivity. Development agencies are rethinking their programmes in this light. The role of reforms to help markets work, facilitate use of information technology and to advance social conditions, and particularly empowering women and girls, all form part of this rethinking process.

Delivering more aid requires significant aid reforms, both to increase value for money and to allow development to take hold. We gave a further push to the concerted donor effort launched in Rome in 2003 on country ownership, donor alignment with country strategies, and harmonisation to reduce transaction costs. Bilateral and multilateral agencies, including the World Bank, the Regional Development Banks and the UN system, together with 14 developing countries, are working closely with the DAC

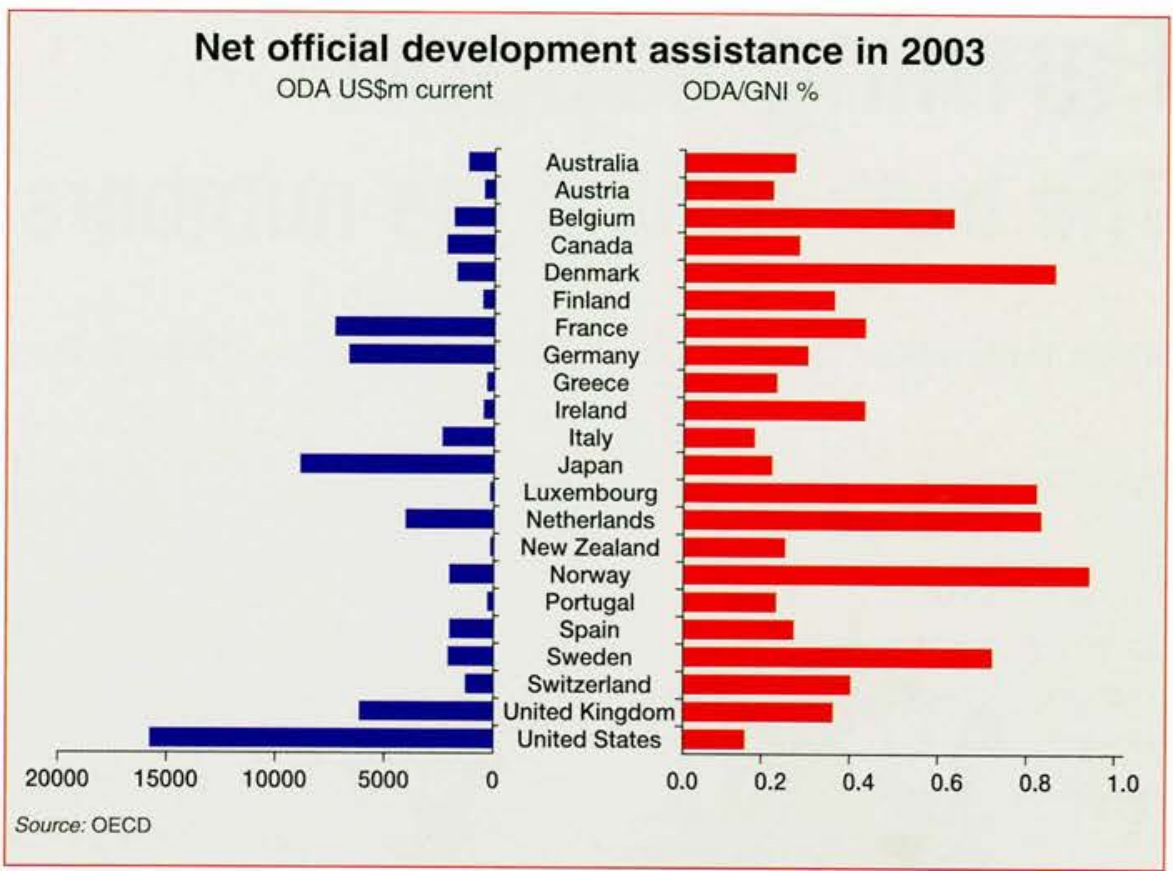

education, disbursed through 33 special budget accounts. In 2003, donors forged a single sector-wide approach, aligned with the government's poverty reduction strategy, with common financial arrangements, joint missions and only three budget accounts.

\section{Stepping up to the challenge of security}

Conflict kills the prospects for broad-based growth. Without security, in its broadest sense, the MDGs will not be attainable for millions of the poor. Development efforts, including many billions of dollars, can be wiped out by war or instability. Our

\section{Development efforts can be wiped out by war or instability. Without security, the Millennium Development Goals will not be attainable for millions.}

to turn the agreed reform principles into practice. We agreed that a further phase of reform should be proposed for adoption at a Paris forum early in 2005.

These efforts can work. The way forward is shown by a recent effort in Bangladesh where 13 donors had 27 projects for primary governments now see security as a major challenge, and a prerequisite of development. The April High-Level Meeting launched a new phase in donor approaches to close the linkages. We endorsed a policy statement and good practices on Security System Reform to help developing countries address their public security systems overall, including the functioning of police and justice systems, civilian control of the armed forces, and protection of human rights. We recognised that helping to reform security systems has to be part of a coherent agenda shared across all relevant parts of our governments. This includes notably the military and foreign policy-makers, as well as development agencies.

We agreed that the credibility of the definition of ODA and the role of the DAC as its guardian must be maintained. ODA reporting guidelines relating to preventing the recruitment of child soldiers, enhancing civil society's role in the security system, and civilian oversight and democratic control of the management of security expenditure were adjusted and clarified. And, with regard to aid provided by members to finance projects under the Clean Development Mechanism, we defined a new rule requiring that the value of any carbon credits acquired by donors should be deducted from ODA. This would ensure consistent reporting in ODA statistics. This will help us not only to define aid more clearly, but to improve its efficacy as well.

\footnotetext{
* Development Assistance Committee High-Level Meeting, 15-16 April 2004. For more information, including a full communiqué, see www.oecd.org/dac
} 


\section{Farming support The truth behind the numbers}

Stefan Tangermann, Director, OECD Food, Agriculture and Fisheries Directorate

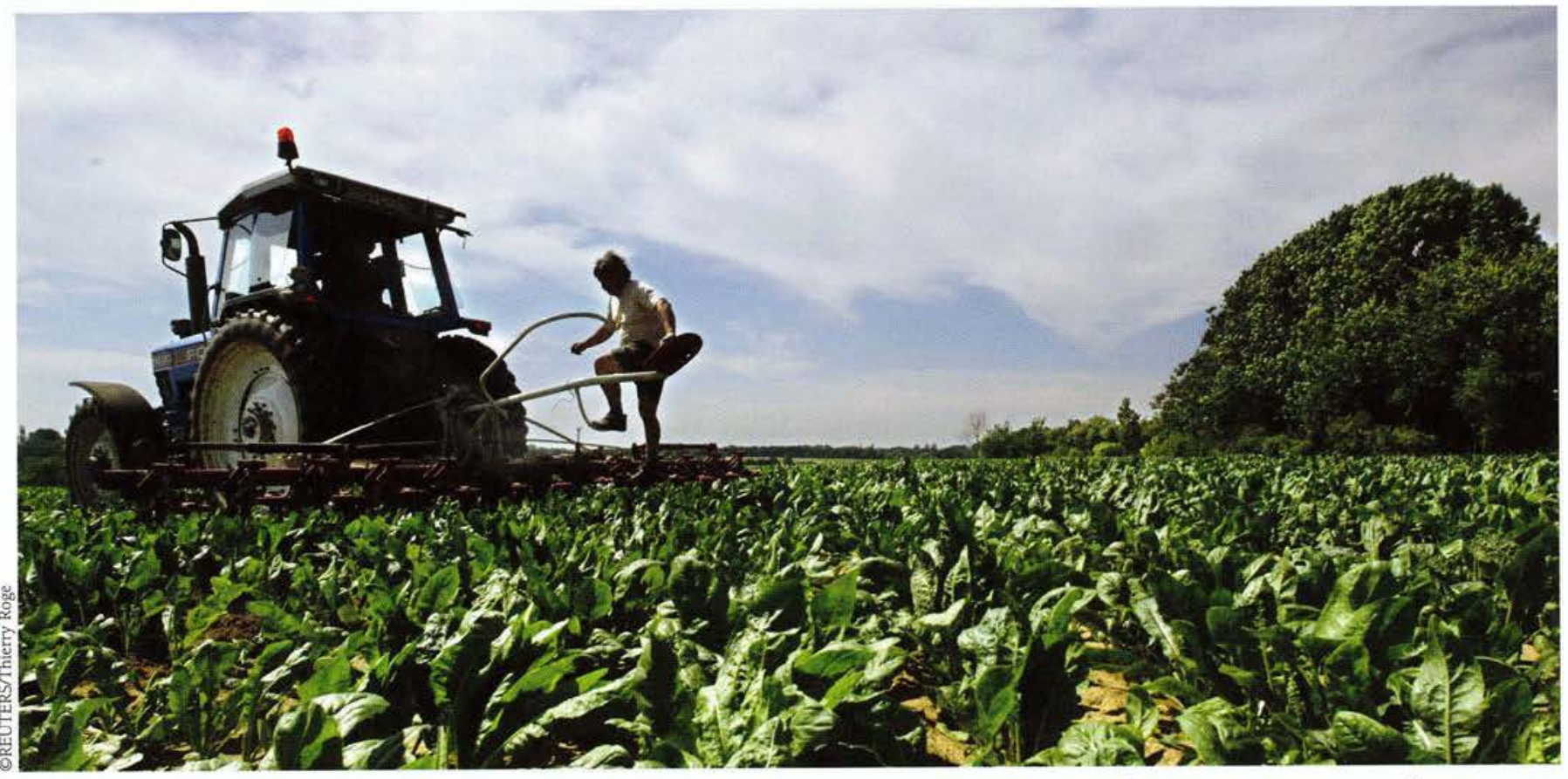

Just how much public money do the world's richest nations spend on supporting their agricultural sector? This is a crucial question in the context of current trade negotiations.

$\mathrm{P}$ ascal Lamy, the European Union trade commissioner, has recently accused Supachai Panitchpakdi, the directorgeneral of the WTO, of using the "misleading" and "contestable" figure of US $\$ 300$ billion for "farm subsidies". This number comes from the OECD, the only institution publishing internationally comparable information on this topic. What lies behind this estimate?

The OECD's aim is to measure the total amount of money transferred through agricultural policies. Many governments support farmers by propping up domestic prices, behind tariff barriers and through export subsidies, but also through public expenditure going directly to farmers. Taken together, these transfers are called the Producer Support Estimate (PSE).

But there is more. Governments also provide support to agriculture in the form of "general services", for example, for research and development, advisory systems and food inspection. The OECD also measures the associated budgetary costs, called the General Services Support Estimate (GSSE). Moreover, in some countries governments also transfer money to poor consumers through food subsidies. Together, the producer support, general services support and taxpayer transfers to poorer consumers represent the OECD's Total Support Estimate (TSE). This indicator, which has been published annually since the mid-1980s, is accepted by all OECD countries. Far from being misleading, it reflects the true overall value of money transferred through agricultural policies.

\section{How much support}

In fact, in 2002, total support to agriculture in OECD countries was just over $\$ 318$ billion. Of this, $\$ 55$ billion was used for general services as outlined above. Another $\$ 28$ billion of taxpayers' money was channeled to poorer consumers, mainly through the food stamp programme in the US. But the lion's share was support going directly to farmers (PSE) to the tune of $\$ 235$ billion, of which $\$ 148$ billion came from higher prices resulting from tariffs and 
export subsidies, and $\$ 87$ billion was transferred by taxpayers through government payments to farmers.

Put another way, this amount of producer support means that as much as 31 cents in each dollar of revenue for the average farmer in the world's richest countries comes from government support. Only the rest comes from the market.

If that is the price society wants to pay in pursuit of goals that markets are not delivering, then such policies may make sense. The fact is, however, that many price support mechanisms simply encourage farmers to produce more than their markets demand, without improving the environment or food safety. Is this sensible, particularly as the resulting trade distortions cause such tension among rich OECD countries, as well as between them and developing countries?

Clearly, in asking how much is spent on agricultural policies, it is crucial to consider overall support, rather than just government payments. Out of the $€ 107$ billion of producer support going to EU farmers in 2002, $€ 61$ billion came from consumers' pockets to pay the high prices caused by tariff protection and export subsidies, and $€ 46$ billion from tax transfers. In the US, total support to farmers was $\$ 40$ billion, of which $\$ 15$ billion came from consumers and $\$ 25$ billion from taxpayers. In Japan, farm support amounted to $¥ 5,500$ billion, of which $¥ 5,000$ billion originated from consumers and $¥ 500$ billion from taxpayers.

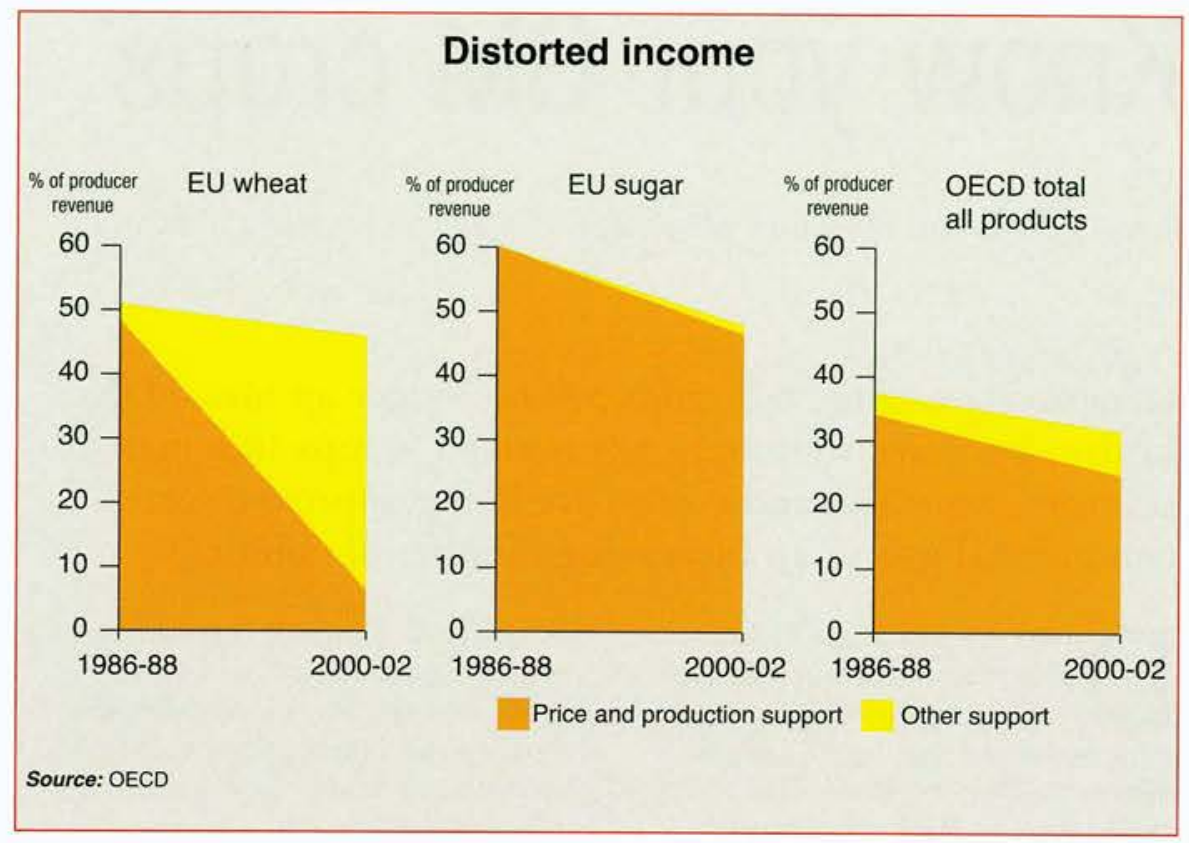

by contrast, applies import tariffs which raise the price paid by consumers and received by farmers. In both cases, the net result is that farmers receive higher prices than the market would generate. And a given price increase, whether via a government cheque or a border tariff, has exactly the same effect on domestic production, trade and farm income.

But not all forms of government expenditure are as distorting. For example, some countries now make fixed payments to farmers, irrespective of what they produce. These payments result in less expansion of production than payments per tonne of wheat or milk produced. The key dividing line to understand is not between

\section{As much as 31 cents in each dollar of revenue for the average farmer in the world's richest countries comes from government support.}

Agricultural policies may come in different forms, but often have much the same effect. That is why the OECD's producer support estimate adds up both government payments to farmers, often referred to as "subsidies", and farm support provided through high prices. For example, in the US, support to wheat farmers comes through a government cheque per tonne of wheat produced, which raises the price farmers receive without raising the price paid by consumers. Japan, government payments and price support, but between policies that primarily distort markets and policies that interfere less with market forces, while also offering a better chance of achieving other important policy objectives in an effective way.

The trouble is, in the 30 OECD countries three quarters of total support still come through the most market-distorting policies, such as price support and payments per unit of production. And as OECD research has shown, such support does a poor job in achieving the objectives pursued by agricultural policymakers, like environmental protection and food safety. These policies are of primary importance in trade negotiations and are prime candidates for domestic reform. Some progress has been made in reducing market-distorting and inefficient support, both in the EU and elsewhere, but it is far too slow. If the world's richest countries want to advance international trade negotiations, they are going to have to bite the bullet and tackle the thorny issue of farm support at home.

The debate is important, and while sound bites of one sort or another help to focus public attention on it, they do not always hit the mark. It is simply not correct to suggest that the only "real support" is that provided by taxpayers through payments directly to farmers. In fact, support provided by consumers through artificially high prices for farm produce is just as trade distorting. This type of support requires urgent attention in WTO talks. It is time to weed out those policies that are ineffective and costly, and focus more on policies that really help governments achieve legitimate domestic goals.

\section{Reference}

- OECD (2002), Agricultural Policies in OECD Countries: A Positive Reform Agenda, Paris. 


\section{Know your GM crops}

Peter Kearns and Masahiro Miyazako, OECD Environment Directorate

\section{Genetically engineered crops are no longer an idea of the future, but have well and truly arrived. Crops like maize, soybean, rapeseed and cotton are being approved for commercial use in an increasing number of countries.}

$\mathrm{D}$ uring the period from 1996 to 2003 , there was a forty-fold increase in the area grown with transgenic crops worldwide, reaching 67.7 million hectares in 2003 (see graph). This is quite a change since the first transgenic crops became commercially available in the mid-1990s. The trend seems set to continue, given the large range of genetically engineered crops that are known to be in research and development

Although two thirds of the transgenic crop area worldwide was found in developed countries in 2003, this was concentrated in only six: the US grew $63 \%$ of the world total, followed by Argentina (21\%), Canada (6\%), Brazil (4\%), China (4\%) and

South Africa (1\%). Most of this area was devoted to soybeans (61\%), maize ( $23 \%$ ), cotton (11\%) and rapeseeds (5\%). So far, most commercialisation has focused on these crops, and has involved two traits: insect resistance and herbicide tolerance.

It is no secret that some people (and countries) are concerned about the safety of these products, which can explain some of the slow uptake in many countries. So it is important for governments to ensure that good quality safety information is made publicly available.

Typically, an approval for the commercial use of a genetically engineered crop - whether for planting and growing in agriculture or for use in human food or animal feed - follows a safety assessment by national authorities and the results are very often publicly available, typically through web sites. There is a large amount of information on the safety of those genetically engineered crops which are in commercial use. One such source is the OECD's Product Database at http://www.oecd.org/scripts/biotech/ which includes many links to the web sites of national authorities.

Confusion can arise when different national authorities share information on the same genetically engineered crop because different names or descriptions can be used for the same product, say, a particular maize or cotton. To avoid this problem, we have published guidance for developing "unique identifiers" for transgenic plants based on the work of the OECD's Working Group on the Harmonisation of Regulatory Oversight in Biotechnology. Think of these unique identifiers as ISBN numbers for books and magazines. They are nine-digit alphanumeric codes that are given to each new transgenic (or genetically engineered) plant that is approved for commercial use. So, for instance, a GM maize developed by Monsanto to be resistant to insect pests has a unique identifier of MON- $\emptyset 810-6$, while DD- $\emptyset 1951 \mathrm{~A}-7$ denotes a cotton developed by DuPont.

The guidance has been designed so that developers of a new transgenic product can generate the identifier. Once approved, national authorities can then forward the unique identifier to us for inclusion in the OECD's database.

It is clear that the guidance works in practice and OECD countries are using it. The EU recently adopted the OECD guidance as its system for generating unique identifiers through a specific commission

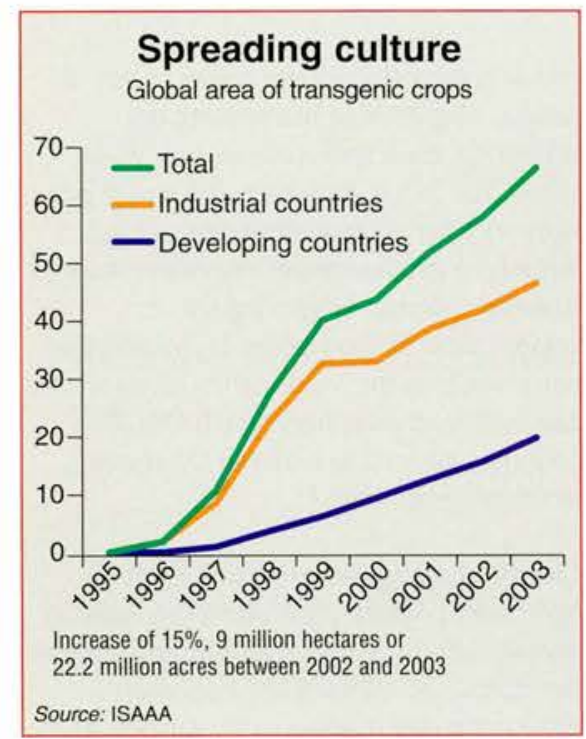

regulation. The guidance has also been recognised as a mechanism for unique identification to be used within the context of the Cartagena Protocol on Biosafety, which is an international agreement covering such products. The OECD has been forwarding unique identifiers to the Biosafety Clearing House (http://bch.biodiv.org/) which is a key part of the Protocol.

The system works well for genetically engineered crops. Still, in this fast moving discipline, it is important to keep pace with technological demands, and we are considering how the identifier tool can be extended to applications other than crops, such as micro-organisms and animals. Thanks to identifiers, all stakeholders, including the public, will be able to access solid and reliable information when making their judgements about safety.

\section{References}

- James, C. (2003), "Global Status of Commercialised Transgenic Crops: 2003", ISAAA Briefs, No. 30, ISAAA, lthaca, NY: http://www.agbiotechnet.com 


\section{Corporate governance}

\section{Stronger principles for better market integrity}

Bill Witherell, Director, OECD Directorate for Finance and Enterprise Affairs

The newly revised OECD Principles of Corporate Governance were released on 22 April. The result is a stronger OECD instrument to help improve boardroom behaviour globally. And that means better business and stronger markets for everyone.

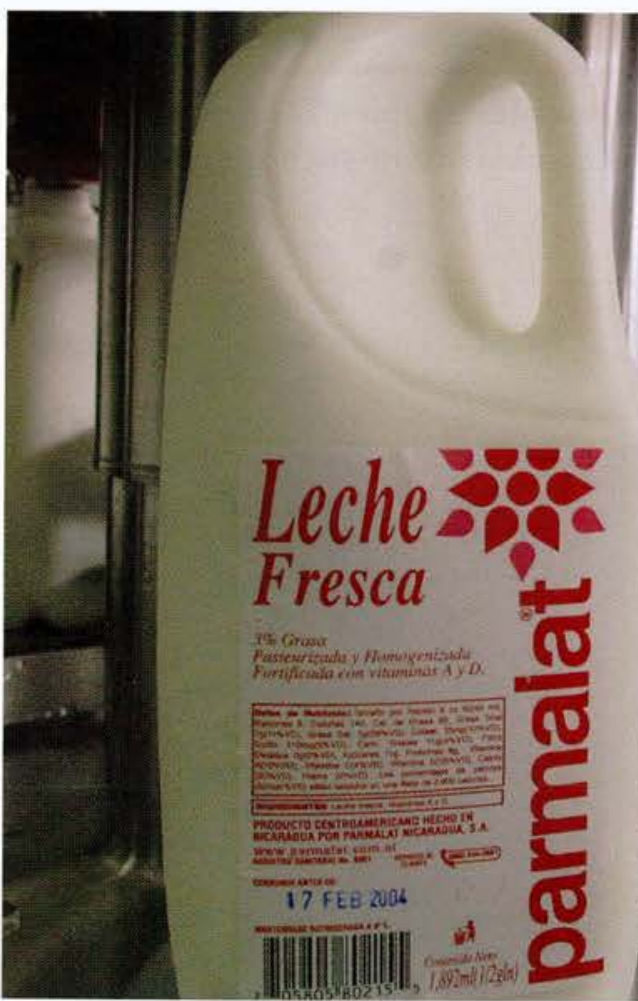

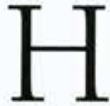

ow healthy are our corporate boardrooms? A vital question

since we all depend on businesses as the engines of wealth creation, innovation and employment, spreading development and technology, and much more. Healthy, well-governed companies make for thriving economies. But we need to rebuild our faith in them. Recent highprofile corporate failures such as Enron in the US or Parmalat in Italy have underlined the continuing need to improve corporate governance globally.
They have also prompted a reexamination of how the OECD Principles of Corporate Governance might be updated to take account of latest developments.

The OECD has worked to promote use of the Principles since they were first adopted in 1999 to support good corporate governance policy and practice both within OECD countries and beyond. Policymakers, investors,

corporations and stakeholders worldwide

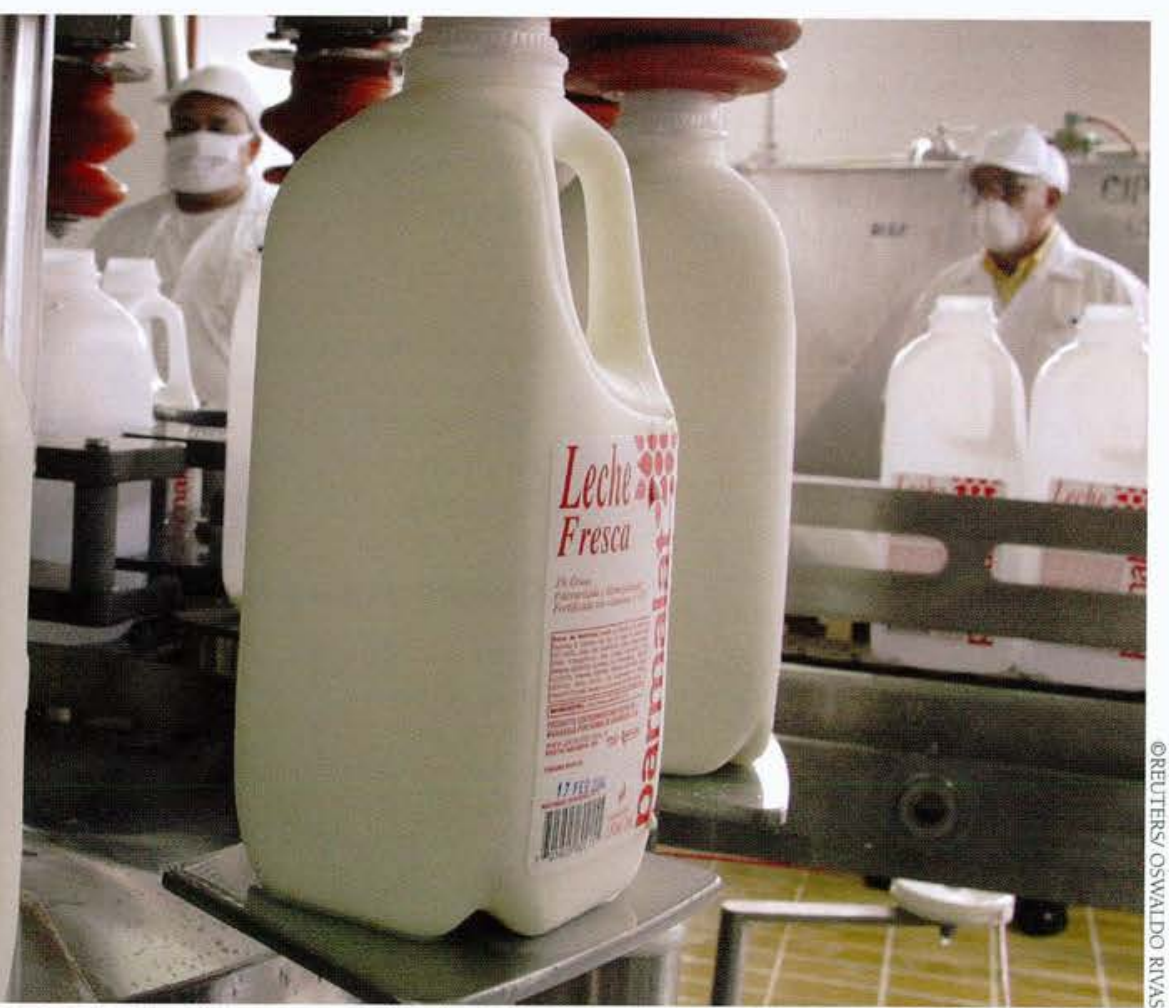

Now for a healthier boardroom 


\section{Truly global}

Fianna Jesover, OECD Directorate for Financial and Enterprise Affairs

The revision of the OECD's corporate governance principles provides a good example of how a more open and dialogueoriented approach can ensure the global relevance of such instruments. The review involved not only consultation with civil society, labour and business in OECD countries, but was based on five years of policy dialogue in regions around the world, as well as putting the Principles to the test.

Corporate governance roundtables involving 38 countries in Asia, Latin America, southeast Europe, Eurasia and Russia have been discussing and introducing their own corporate governance reforms, using the OECD Principles of Corporate Governance as a benchmark.
While this shows that the Principles apply well beyond the OECD area, the process has been two-way, as lessons from the 25 roundtable meetings and several public consultations were taken into account in making the new revisions.

A range of issues were taken on board. One significant example was enforcement, a severe challenge even when the legal framework is adequate. In many cases implementation of rules and regulations is deficient, with some cases of inconsistencies, since the design bears little relation to the institutional and human resources available. These concerns are reflected in a new chapter that provides more guidance on creating a sound regulatory system, such as by clearly delineating the competencies of different regulatory agencies to support the corporate governance framework.

Concentrated and opaque ownership structures are a feature in a number of non-
OECD countries, as is weak minority shareholder protection. In such situations those in control can structure commercial transactions with their own private companies, family, etc., to benefit themselves at the expense of the company or its smaller shareholders. The Principles now include added guidance on disclosure of transactions between related parties so as to prevent abuse.

Moreover, there is strong support for disclosing conflicts of interest by board members and major investors, as well as for improving transparency. And the fiduciary duties of board members have been clarified in a bid to deal with opaque and concentrated ownership structures. For instance, their duty is not to the group as a whole, but to the company where they are a board member, and they are required to treat all shareholders equally.

See: www.oecd.org/daf/corporate/principles have used the Principles to tackle a broad set of relevant issues common to all, such as the need for transparent reporting, informed shareholders and accountable boards. Regional roundtables on corporate governance set up in partnership with the World Bank have allowed the OECD Principles to become a widely accepted global benchmark that is adaptable to varying social, legal and economic contexts in individual countries. They have helped to spur reforms in regions as diverse as Asia, Latin America, Eurasia, southeast Europe and Russia.

Yet, the recent spate of scandals highlighted corporate governance weaknesses and naturally led to the question of whether the Principles had been on the mark or missed something important - or indeed to what extent companies, boards and investors may have simply failed to follow good practice. The OECD ministers called in 2002 for an assessment of the Principles by 2004 to take such questions into account. A steering group was set up and intensive consultations were begun with leading business and labour representatives. In addition, comprehensive and transparent consultations with civil society were organised, culminating in January 2004 in a draft of the revised Principles posted on the Internet for public comment.

The Steering Group also conducted a Survey of Corporate Governance Developments in OECD Countries to identify lessons learned investment climate. These links to investment, public savings, market confidence and integrity make good corporate governance a central policy concern of importance to long-term economic growth and financial market stability.

\section{The Principles already called for boards capable of independent judgement, yet in case after case the absence of such independence proved fatal.}

from experience and possible implications for the assessment of the Principles. This survey and a separate review, Experiences from the Regional Corporate Governance Roundtables, further informed the review.

\section{Diagnosis and treatment}

It has become clear from these consultations and research that the benefits of good corporate governance are now widely understood. Good corporate governance is not simply about minimising the risk of corporate failure and dealing with those guilty of fraud. It is also a fundamental prerequisite for improving economic performance, facilitating corporate access to capital, decreasing volatility in retirement savings and improving the general
Indeed, the review found that the original Principles represented the requirements for good corporate governance reasonably well. The difficulties arose largely in ensuring their effective implementation. The Principles already called for boards capable of independent judgement, yet in case after case the absence of such independence proved fatal. Shareholder rights to appoint board members were supposed to lead to accountable boards, but one question repeatedly raised in the consultations was: where were the informed owners? The Principles called for independent audits which in all too many instances proved a mirage. They called for transparency of ownership structures, but these structures remain opaque in many countries. 
On the other hand, the Principles did not address issues of public concern in some countries, such as executive compensation, and the rise of institutional investors was only dealt with tangentially.

The 1999 Principles have now been strengthened to respond to the new challenges and concerns highlighted in the consultations. These revisions cover four main areas: ensuring the basis for an effective corporate governance framework including effective regulatory and enforcement mechanisms; improving possibilities for the exercise of informed ownership by shareholders; a strengthening of board oversight of management; and increasing attention to conflicts of interest through enhanced disclosure and transparency. The non-binding principlesbased approach, which recognises the need to adapt implementation to a wide range of legal, economic and cultural circumstances, was applauded as a key strength of the Principles, and has been retained. And while the revised annotations avoid excessive prescription, they also respond to many requests for more guidance as to how the Principles could be implemented and enforced through references to evolving practices.

To improve implementation, a new chapter has been added specifying principles for governments to follow in developing the regulatory framework which underpins good corporate governance. Broad principles have been developed covering implementation and enforcement, along with mechanisms that should be established for parties to protect their rights. However, the Principles seek to minimise the risk of over-regulation and the costs from unintended consequences of policy action, both of which have been raised by business groups as potential dangers.

At the end of the day, good corporate governance comes down to effective and informed owners. These have all too often been absent. The chapter on shareholders has now been strengthened with the aim of lowering the cost and raising the return from the informed use of ownership rights. New principles call on institutional investors to disclose their corporate governance policies, including how they decide on the use of their voting rights and how they manage conflicts of interest that may compromise their voting. Restrictions on consultations between shareholders about their voting intentions should be eased, thereby reducing the cost of informed ownership.

The rights of investors have also been strengthened. Shareholders should be able to remove board members and participate in the nomination and election processes. Shareholders should also be able to make their views known about the executive and board remuneration policy of the company, and any equity component should be subject to their approval.

As to the board, its responsibilities have been more clearly specified to address corporate ethics, compliance with laws and standards and oversight of internal control systems covering financial reporting, all of which have at one time or another appeared weak. The principle covering board independence and objectivity has been extended to apply to situations characterised by block and controlling shareholders, and not just referring to independence from agencies and analysts, whose advice should not be compromised by conflicts of interest. The Principles aim to make auditors more accountable to shareholders, for example, by exercising due professional care in the conduct of the audit. Greater attention is paid to ensuring auditor independence.

\section{Prognosis}

Being principles-based and nonprescriptive, the success of the Principles will rely upon how they are actually applied in a given situation by companies, shareholders, stakeholders and governments. There will always be a question of whether the balance of soft and hard law is appropriate and why the behaviour of companies, shareholders and stakeholders might not be responding in ways considered conducive to good corporate governance. Sharing of experiences on implementation strategies and "good practice" interpretation will, therefore, be crucial and will need to extend to a wide range of people, not just the authorities. OECD endorsement of the revised Principles should reassure market players and non-OECD partners that member countries are committed to just

\section{Greater attention is paid to ensuring auditor independence.}

management, though this remains critical. However, the Principles do not advocate independence for the sake of it, and lay as much stress on the capabilities of board members. Quality should be ensured not just by more careful selection from a wider group of candidates but also, if necessary, through continued training.

One of the most striking features of corporate governance practices in recent years is that conflicts of interest appear to be widespread and can be quite pernicious. The principles covering disclosure have been strengthened, particularly with respect to those conflicts of interest and transactions between related parties, which in addition to being approved by the board also need to be disclosed. A new principle recognises the role of various providers of corporate information, such as ratings such a sustained dialogue. The support of such dialogue will be at the core of the OECD's mandate. By working together in this principled way, our companies and our economies should be able to look forward to a cleaner bill of health.

\section{References}

- The revised Principles of Corporate Governance are available at: www.oecd.org/daf/corporate/principles

- OECD (2004), Corporate Governance: A Survey of OECD Countries, Paris.

- OECD (2003), Experiences from the Regional Corporate Governance Roundtables can be found on the OECD corporate governance website: www.oecd.org/corporate/

- OECD (2003), "Roundtables on Boardrooms", OECD Observer No. 238, July 2003.

- See also OECD Observer No. 234, with a special section on corporate governance, October 2002. www.oecdobserver.org/governance 


\section{Resolving international tax disputes The role of the OECD}

Jeffrey Owens, Director, OECD Centre for Tax Policy and Administration

The dramatic growth of crossborder trade and investment has raised an increasing number of international taxation issues. As economic activity involves more and more countries, questions involving the interaction of national tax systems have increased.

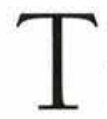

ax rules which were fashioned in a more closed economic environment can

discourage international activity. They can create conflict between countries as to the appropriate tax treatment of an international business and between taxpayers and governments. Unresolved international tax disputes can undermine co-operation and discourage investment, and so become a serious impediment to global development. Clearly we must try and help ensure that such disputes do not arise and, if they do, provide procedures for resolving them.

Much of the work to date at the OECD has been in helping to fashion substantive principles and practices which can lessen the possibilities of tax conflicts. The Model Convention for the Avoidance of Double Taxation and the Transfer Pricing Guidelines are two of the principal contributions which the OECD has made in this area. These instruments form the bases for global co-operation in dealing with these questions.

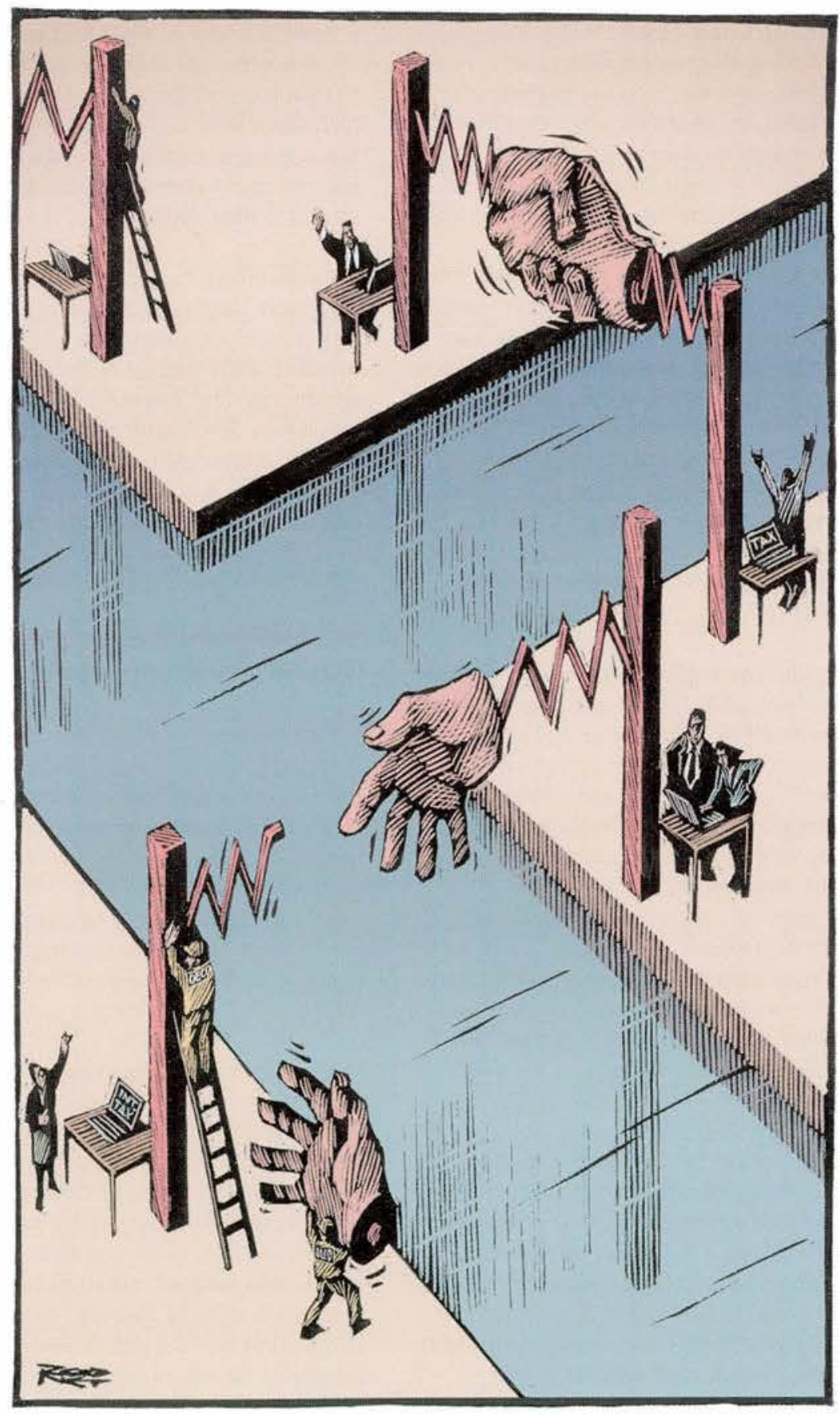


But, however well the rules are crafted, there will inevitably be situations where disagreements arise; hence, the need to develop procedures through which these conflicts can be resolved.

Two important initiatives have been undertaken by the OECD Committee on Fiscal Affairs in the procedural area. The first is the development of so-called Advance Pricing Agreements (APAs) to deal with potential disputes. One of the most important issues concerning multinational corporations is the allocation of the overall income from the transactions between the various taxing jurisdictions involved. Generally speaking, large multinational groups that produce or distribute goods or services use subsidiaries and parent companies located in different jurisdictions. The group naturally wishes to calculate its tax liabilities in such a way as to concentrate payments in lower tax regimes.

With internal accounting, global firms can shift profits among companies and lessen their overall tax bill, or even avoid tax in some jurisdictions altogether. However, this "transfer pricing" obviously raises a double-edged problem: no tax authority wishes to be short-changed from legitimate tax revenue, and no business wants to be double-taxed by different governments for the same profit.

The Transfer Pricing Guidelines provide a framework to help authorities and businesses to attribute to each jurisdiction in which related companies do business the amount of income which would have been generated if the parties had been acting as quite separate and unrelated businesses. But applying these "arm's length" standards in concrete situations is difficult and complex, and can still lead to disagreements, even costly and protracted litigation.

This is where the Advance Pricing Agreement procedure comes in. The multilateral APA process allows the taxpayers and the governments involved to reach agreement in principle on the appropriate taxation methods to apply to a particular case before the transaction takes place. The business submits to the tax authorities the economic information necessary to determine the exact nature of the underlying transactions and the tax authorities, using the various approaches developed in the Transfer Pricing Guidelines, can then agree on the appropriate methodology to apply to the case. The APA does not settle all of the details as to how the transaction will be taxed, but simply establishes the basic framework by which the transactions will be analysed. APA builds trust between the parties: the likelihood of double taxation is greatly diminished and the jurisdictions involved can feel satisfied about their share of the tax revenue likely to be generated from the transactions. operates in an open and transparent fashion. One key step to improving the transparency of the process was taken in April 2004 by posting Country Profiles on MAP used by OECD countries on the OECD website (see references). NonOECD countries will be invited to provide their profiles on the website too.

In addition, we are looking in some detail at a range of supplementary dispute resolution techniques, which can help to ensure that international tax disputes are brought to a satisfactory conclusion. These techniques could include the possibility of involving special mediators to help resolve difficult cases and arbitration procedures to help achieve a

\section{No tax authority wishes to be short-changed from legitimate tax revenue, and no business wants to be double-taxed by different governments for the same profit.}

Despite all this, costly disputes inevitably arise, which is why the OECD is working to improve the procedural mechanisms.

The present Mutual Agreement Procedure (MAP) is a dispute resolution process laid out in the OECD Model Tax Convention and incorporated in bilateral tax treaties. Under the MAP process, taxpayers who are subject to potential double taxation can ask the countries involved to meet together to try to resolve the dispute over taxing rights. MAP has worked effectively, but is increasingly being put under strain because of the sharply rising volume and complexity of cases it has to deal with. A review of the dispute resolution process in the tax area is now in progress. It is clear that the MAP process will continue to be the basic mechanism for the resolution of international tax disputes. However, there are a number of areas where the existing procedures can be improved and the work has highlighted situations in which obstacles to the use of the MAP can be eliminated.

In particular, as our consultations with the public have pointed out, it is important to ensure that the MAP process final and consistent resolution of outstanding cases. A possible structure for such procedures is being developed for use by those countries wishing to adopt arbitration procedures in their bilateral conventions.

The OECD is a consensus organisation and does not generate "hard law" but principles and agreed guidelines. Under this approach, it is unavoidable that differences in interpretation and application will arise. As a result, it is equally important to ensure that there is a well-functioning procedural mechanism to deal with tax disputes when they do arise.

\section{References}

- OECD (1999), Transfer Pricing Guidelines for Multinational Enterprises and Tax Administrations, Paris.

- OECD (2002), Model Tax Convention on Income and on Capital, Volumes I and II: Update 2002, Paris.

- Dispute Resolution: www.oecd.org/ctp, click on "Dispute Resolution".

- Neighbour, J. (2002), "Transfer pricing: Keeping it at arm's length", OECD Observer No. 230, January 2002.

- Centre for Tax Policy and Administration website: www.oecd.org/ctp 


\title{
Small and medium enterprises Seizing the potential
}

\author{
Herwig Schlögl, OECD Deputy Secretary-General
}

\section{Small and medium-sized firms dominate our economies in terms of employment and number of companies, yet their full potential remains} remarkably untapped. This needs to change.

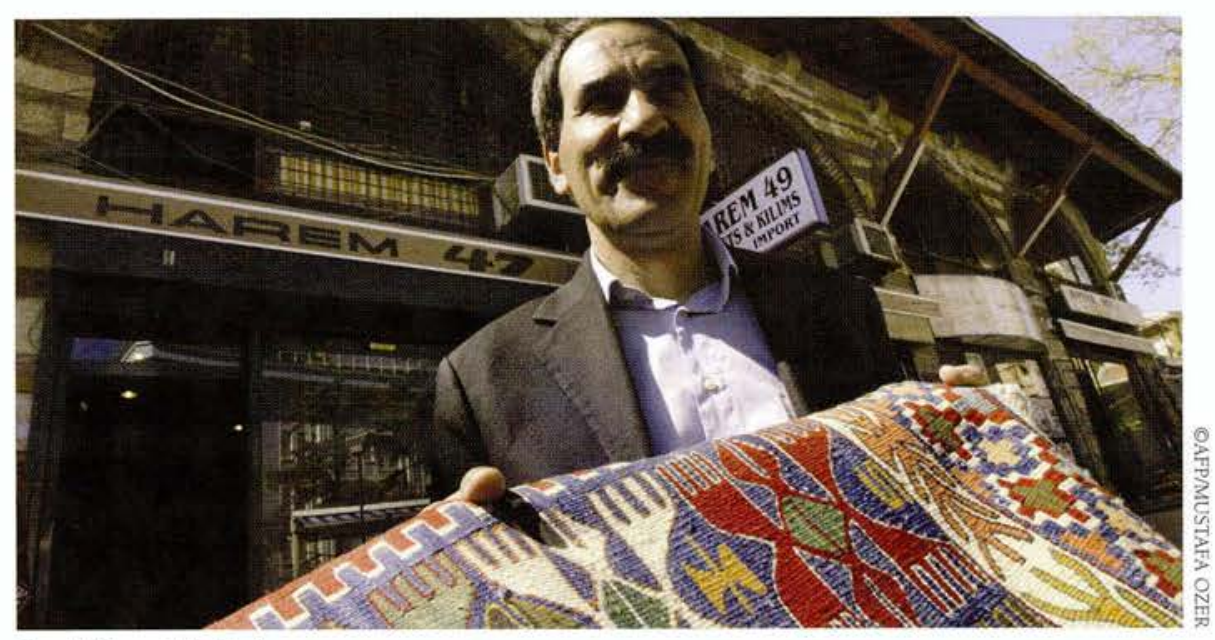

Small firm, big designs

regions. Boosting women's entrepreneurship, which is undeveloped throughout the OECD area, is another attraction, since this can help raise female participation in the workforce as well as spur productivity. And that means stronger growth for everyone.

The OECD has played a leading role in bringing the importance of SMEs into the public policy spotlight. We launched the Bologna Process in 2000, and are now looking forward to building on this work in Turkey in June 2004 (see box, article by Ali Coskun, page 48).

The ability of smaller firms to
create jobs is clearly a major
attraction for governments in the
short term, but by encouraging
more SMEs to flourish, we can
realise other economic and
social objectives too.

The ability of smaller firms to create jobs is clearly a major The ability of smaller firms to create jobs is clearly a major attraction for governments in the short term, but by encouraging more SMEs to flourish, we can realise other economic and social objectives too, like expanding worker skills or even alleviating pockets of local poverty in inner cities or declining
We strongly believe that, with the right policies and frameworks, SMEs have a huge role to play. Countless firms enter and exit the market every year. While differences in the birth rates of firms are not very significant from country to country, young firms seem more likely to grow in the United States than in most European countries. The causes of this disparity owe much to the business climate, as well as to institutional and administrative differences, costs, and so on.

What can governments do? Overall, they must work to deliver a general business environment that is conducive to entrepreneurship, firm creation and to the rapid growth of innovative firms. This calls for sound fiscal and monetary policies, and structural reform to allow labour and product markets to function smoothly. That may mean taking action in areas like taxation, competition, financial markets and, of course, bankruptcy rules. It is crucial to ask early on if these policies dampen or enhance 
enterprise creation and respond to the needs of SMEs.

Regulatory and administrative costs can obviously impinge on entrepreneurial activity, dampen investment and R\&D, and stunt firm growth. They can put firms out of business by absorbing too much time and resources. Even difficult exit conditions that make it costly for firms to wind down, such as lengthy creditor claims on assets or heavy redundancy rules, can discourage start-ups at the very outset.

Culture is another important factor for building an entrepreneurial society, influencing career preferences and shaping attitudes to risk-taking and reward. Governments have a role to play, via formal education and training (including lifelong learning), and fostering entrepreneurial attitudes.

With such an array of challenges, it is not surprising that SME participation in international markets lags significantly behind that of larger firms, whose command of resources and global reach can be significant. Some great innovations have come from SMEs, particularly in technological fields, but these often owe much to larger networks. Many entrepreneurs are seizing these opportunities and, indeed, global market access has become a strategic necessity. More could be done to help them, and in more complete ways - not just with marketing, but by providing easy access to information in such areas as tax, regulatory frameworks, trade rules, and other legal and advisory services. Helping them to gain access to finance is also important. Indeed, financing is frequently a major hurdle to overcome on the way to setting up and staying in business, with access to risk capital in particular being especially problematic in many countries.

There may be infrastructure issues governments could address, like expanding broadband and secure servers, since despite some success stories, SMEs in general have been slower than large firms to take to e-business. One reason is vulnerability to absorbing costs if

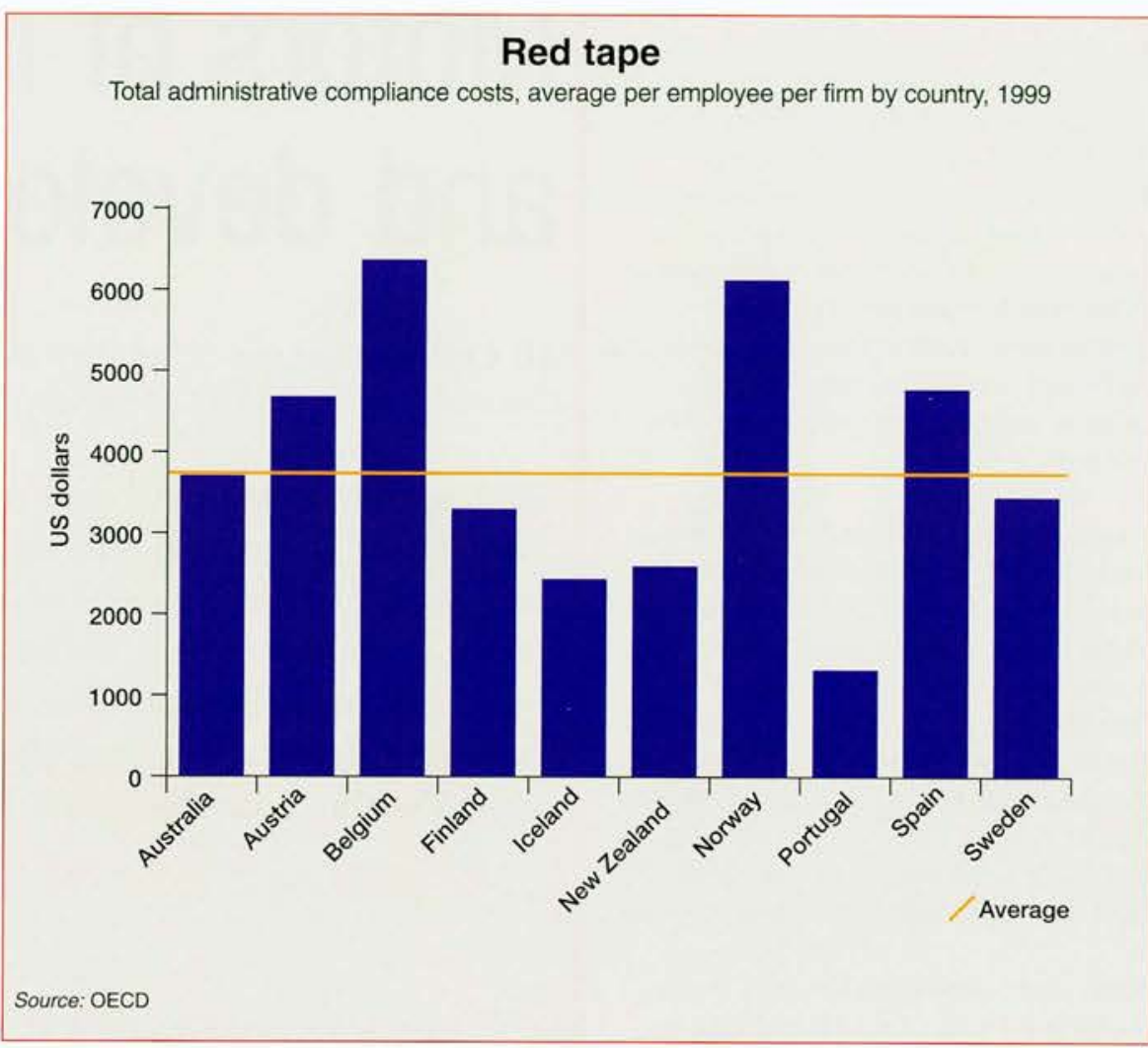

transactions go wrong. Also, assuming there are e-solutions to their problems, SMEs frequently cannot afford or find qualified e-business staff. These major impediments for smaller firms simply lengthen the usual list of problems relating to trust, transaction security and, crucially, concerns about violations of intellectual property rights.

Only when the regulatory infrastructure throughout the entire system is worked out will SMEs be able to take full advantage of e-business. For instance, a low-cost online dispute resolution (ODR) mechanism among firms, and between firms and consumers, may be worth considering, and a concrete SME-related proposal will be presented to ministers for discussion.

\section{The agenda}

These are just some of the concrete issues that will be on the agenda for discussion at Istanbul. It will be part of an ongoing dialogue, also involving entrepreneurs themselves. The OECD Bologna Process

\section{The Istanbul conference}

The Second OECD Ministerial Conference on SMEs, "Promoting Entrepreneurship and Innovative SMEs in a Global Economy: Towards a More Responsible and Inclusive

Globalisation", takes place in Istanbul, Turkey, 3-5 June 2004. It builds on the Bologna Process, launched at the first conference in Italy in 2000. Hosted by Turkey's Ministry of Trade and Industry, the Istanbul conference will provide an opportunity to assess the impact on SMEs of new developments relating to globalisation, further increase the understanding of issues and policies related to entrepreneurship, and identify best practices, as well as strengthening international policy dialogue.

Four main ministerial workshops will treat the following themes: i) Entrepreneurship and SME Innovation; ii) Tools for SME Innovation;

iii) SMEs in the Global Economy; and

iv) Enhancing the Role of SMEs for

Development. There will also be a special workshop on SME and entrepreneurship statistics. In addition to the 30 OECD member countries, the Istanbul conference will gather 57 non-OECD countries, as well as 66 international organisations and civil society groups. The meeting is expected to produce an OECD Action Plan. 
SMES

membership now numbers 57 non-OECD countries, so we have a great opportunity to address these challenges head-on. A broad agenda based on reform and improving regulatory "quality" is needed and the June conference is expected to culminate in the adoption of an Istanbul Ministerial Declaration, in which governments reaffirm their commitment to SMEs and entrepreneurship through a range of policy actions addressing these problems.

Foremost among our goals is how to foster the role of SMEs for development. Indeed we must consider how SMEs might play a more vigorous role within international strategies, like the Doha Development Agenda, the Monterrey Consensus, the OECD Action for a Shared Development Agenda and the G8 Africa Plan of Action. Clearly, SMEs could make a valuable contribution to our efforts to meet the Millennium Development Goals.

These many challenges demand lucid decision-making, and so a key area we need to reinforce is the quality and amount of data we collect. Building databases and indicators is an endless, yet vital, task for understanding SMEs more thoroughly, checking progress and comparing situations between countries.

Expectations are high as we prepare for Istanbul. Apart from the ministerial, there will be a business symposium, and a special women entrepreneurship programme and workshop to exploit to the full. An Action Plan could be forged from this hub of highlevel exchanges and activity. In short, we must take advantage of the Istanbul conference, not as a talk shop, but as a golden opportunity to show that small is indeed beautiful and that we are serious about building a more responsible and inclusive globalisation.

\section{References}

- OECD (2003), OECD Small and Medium Enterprise Outlook, Paris.

- For information on the OECD SME ministerial: www.oecd-istanbul.sme2004.org/

- OECD (2003), "Smart, as well as beautiful: the Bologna Process", OECD Observer No. 238 , July 2003, Paris.

- SME website: www.oecd.org/sti/smes/

\section{Motors of innovation and development}

Ali Coskun, Minister of Industry and Trade of the Republic of Turkey and Chair of the Second OECD ministerial conference on SMEs

\section{The potential of small and medium-sized enterprises to contribute to growth and development is a point that has} not been lost in the case of Turkey. On the contrary, as in most other countries, SMEs are the dominant form of business organisation here, accounting for over $95 \%$ of the business population, and they play a key role in driving sustainable economic growth and job creation.

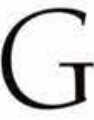
iven their huge number and large share of the workforce, the Turkish government has for many years carried out a variety of programmes and support measures for the development of these enterprises. The number and the extent of these programmes and support measures increased significantly when the EUTurkey Customs Union came into force on 1 January 1996. As a candidate for membership of the European Union, Turkey ratified the European Charter for Small Enterprises in April 2002 and participates in the Multi-annual Programme for Enterprise and Entrepreneurship (MAP) 2001-2005.

So, we take the future of SMEs very seriously indeed. The Second OECD ministerial conference on "Promoting Entrepreneurship and Innovative SMEs in a Global Economy", jointly organised by the Ministry of Industry and Trade and the OECD, which will take place in Istanbul on 3-5 June 2004, is evidence of the Turkish government's strong interest and involvement in this area. It is also recognition of the lead that the OECD has taken in bringing SME issues to the attention of busy policymakers everywhere.

The conference, which will bring together participants from OECD countries and around 57 non-OECD economies as well as representatives of international organisations, will specifically focus on entrepreneurship and innovation. The first ministerial conference on SMEs was held in Bologna in 2000. Turkey actively participated in this event, and helped to secure the adoption of the Bologna Charter on SME Policies.

Considering that SMEs are very sensitive to changes in the business environment as they might be the first to be affected by political and economic developments, the Turkish Ministry of Industry and Trade established the Small and Medium Industry Development Organisation (KOSGEB) in 1973 with the aim of increasing the share of SMEs in the Turkish economy, and helping them to upgrade their structures and achieve their integration within Turkish industry more generally.

The average profile of Turkish SMEs is quite different from that of most OECD-European 


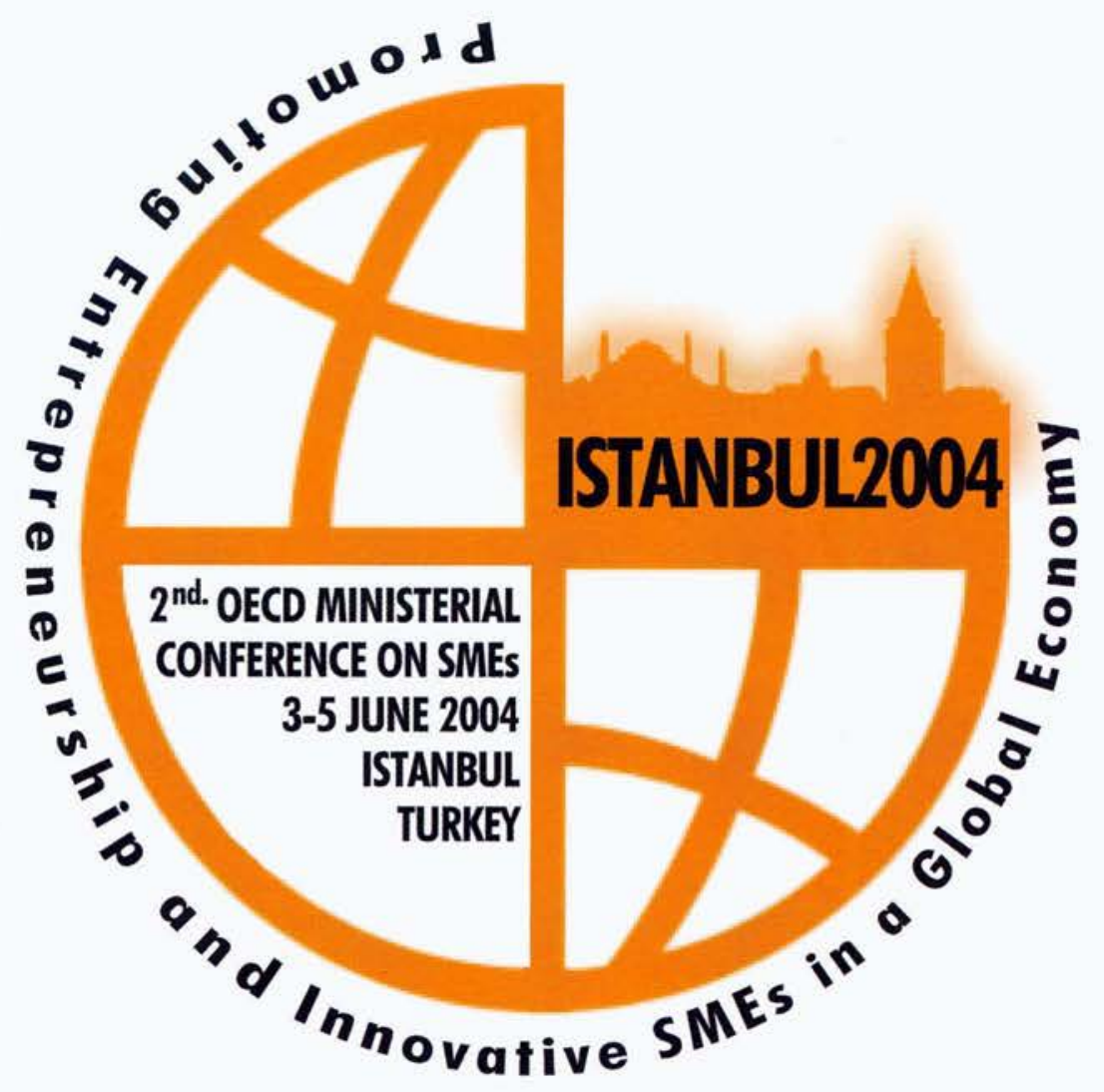

countries. Their average workforce and turnover are much smaller. As in most other countries, they have difficulty obtaining financing. Furthermore, the share of the agricultural sector and the level of the rural population employed in agriculture in Turkey are higher than the OECD average. However, this situation is changing fast, as urbanisation gathers pace and is now approaching the average of other developed countries.

The fundamental strategy developed for small and medium-sized enterprises in the eighth Five-Year Development Plan - the major policy document for the current period - and the policies envisaged in the National Programme for Accession to EU foresee an increase in SME efficiency, of their share in the value added and their international competitiveness.

Policies and programmes are being developed to create a more favourable investment environment for SMEs, the market-making role and areas of intervention of the state are being identified, and recommendations are being developed to define the role of the private sector to increase the effectiveness of those policies and programmes.

The main problems facing Turkish SMEs in their development and ability to improve competitiveness in world markets are as follows: first, insufficient know-how and low level of technology; second, an unfavourable financial environment; and third, insufficient training.

We have taken action to solve these problems, with a process launched in 2003. Our aim is to increase value-added, competitive power and technological level of SMEs, to carry them to international markets and to help them create their own brands. As a result of this process, the number of KOSGEB support
The number of support instruments for SMEs has risen sharply. Heavy bureaucratic procedures have also been simplified. instruments has risen from 8 before to 38 . Heavy bureaucratic procedures required to apply for them have also been simplified. The amount of aid for SMEs operating in less developed regions has been increased at a rate much higher than in developed regions.

Some 12 technology development zones and techno-parks have been created to encourage university-industry co-operation. Besides, SME exchanges have been established to strengthen their financial positioning. And venture capital companies are being set up to support young entrepreneurs.

These may not be enormous initiatives taken individually, but together they make a huge difference. We look forward to sharing our lessons with colleagues and experts from around the world and to learning how our work might be improved. Given the potential of SMEs in our economies and societies, our joint efforts will be worth it. 


\title{
Renewal and innovation A condition of the health of nations
}

\author{
Arnoud De Meyer, Professor of Technology Management and Deputy Dean at INSEAD*
}

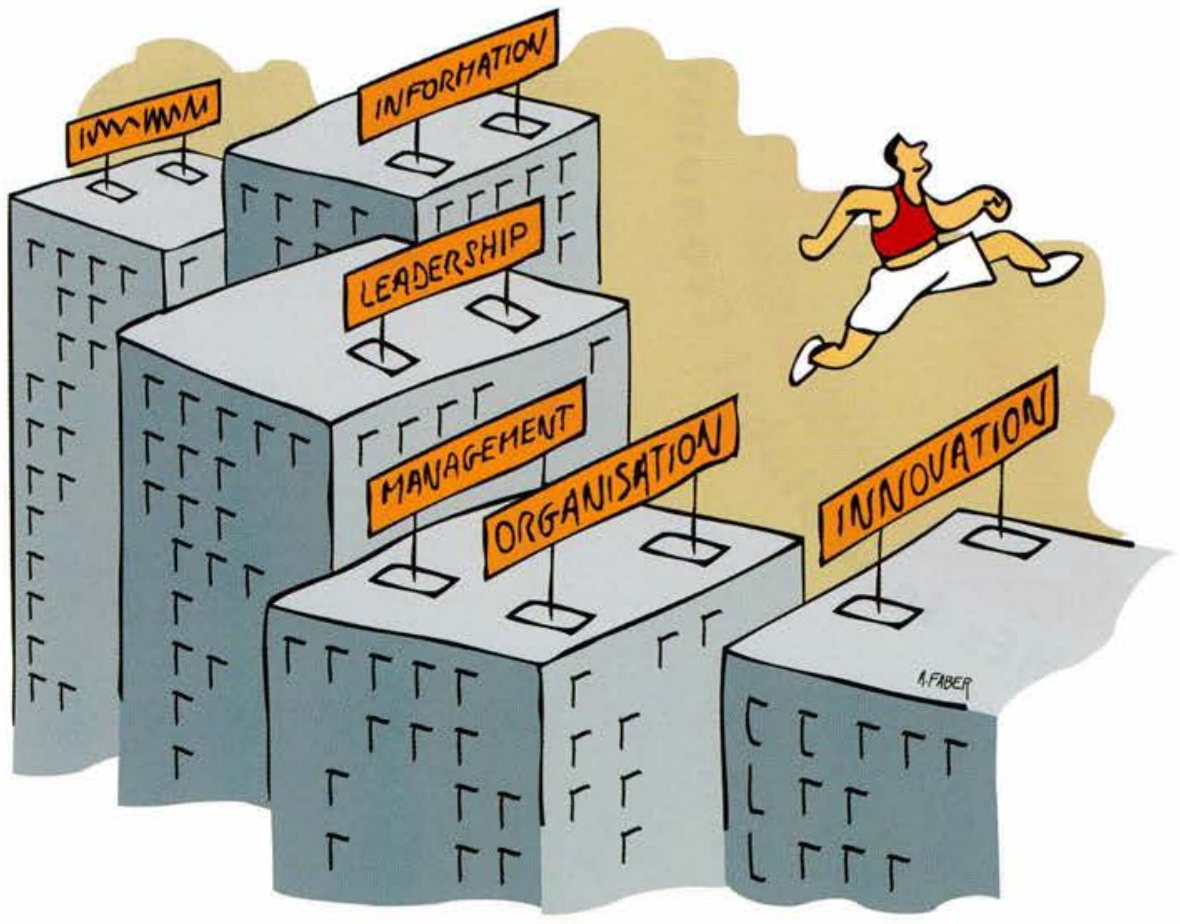

Firms and organisations, indeed whole nations, have to adapt fast to changing situations and demands.

That means constant renewal. Everyone can succeed, some more than others, as long as they bear in mind the following key organisational principles.

or a nation to be healthy requires an
ability to renew itself constantly. This
applies to companies, organisations, governments, indeed everyone. The need to innovate is obviously not new. The fathers of management, be it Frederick Taylor, Henri Fayol or Joseph Schumpeter, wrote volumes on how innovation affects production and economics. And managing innovation has been central to management studies since the early work by Tom Burns and George Stalker on innovation management, the SAPPHO studies in the UK comparing successful and unsuccessful innovations, or the work carried out for the Apollo and Gemini space projects in the early 1960s. But innovation has become an even bigger imperative than it used to be in OECD countries, and this is for at least three reasons.

First, the economic landscape is changing. Globalisation, the rise of China and India as economic powers, and the geographical relocation not just of production, but R\&D too, pose a major challenge for the "industrialised" world. There are new technology leaders, like Korea in the applications of broadband, or Singapore in biotechnology.

Second, customers for new products, systems or services, and citizens as clients of government have become far better informed and more demanding about both design and quality.

Thirdly, the possibilities offered by information and communication technologies enable a much faster diffusion of innovation worldwide, so much so that the sources of innovative ideas crop up in places where we do not necessarily expect them. Take SMS (short messaging systems), some of whose best innovations come out of Manila, or the Indian movie industry. Or consider Ireland, which has emerged as a hub of activity in IT and pharmaceuticals, much to the surprise of many economists.

The trouble with innovation is that while it is becoming ever more important for success, it is a very risky enterprise. The traditional literature exploring the subject all draws discouraging conclusions: the prospects of the innovator "making it" are slim. Overall it appears from most research that the probability of economic success from innovation is between $20 \%$ and $30 \%$. The implication is simple: we need to have the guts to live with risk if we want to innovate for our health!

We must learn how to improve our chances of success. The good news is that three decades of management literature have produced a lot of insights on how to do this. There are hundreds of good ideas, and they can be summarised into eight categories.

The first, appropriately, is leadership. Successful innovation requires a clear vision 
defined by the leadership of the organisation as well as the creation of an environment where this vision can be shared by colleagues and collaborators. This combination of vision and environment is what I call the "strategic context". Organisations rely on it to harness their creativity. Without a clear strategic context, creativity may blossom, but it will be disjointed. Strategic context gives purpose and direction, benchmarks and role models. It measures progress and shows the way ahead.

The second strategic point is to learn how to manage risk. This includes ensuring that the senior and junior players in an organisation act as innovators and entrepreneurs, and that they can inspire their collaborators to do the same. All of us have some entrepreneurial talents, some of us more than others. Those who have a lot probably take the jump and start a venture (whether in the profit or nonprofit domain). But most of us need the security of a larger organisation combined with stimulus to bring out the best in us. Taking risks is not just about jumping in foolishly, but assessing in a cool and rational way what the risks are and preparing contingencies to cope with all kinds of uncertainty. functional, project oriented, networked, etc. But the most important insight for me is that to implement innovation the whole organisation has to take ownership of it. Innovation cannot be delegated to a development group, task force or marketing department. From the first spark of inspiration to the full readiness of the product, service or system, top and operational levels have to be mobilised together if the innovation is to work.

Then comes implementation. Echoing Edison and other great inventors-entrepreneurs, everyone knows that success is $2 \%$ inspiration and $98 \%$ perspiration. We also know that the best ideas can be overtaken by events. This is why, under situations of high uncertainty, project management is so vital. Managing the unknowable requires astute knowledge management, as well as skill in handling stakeholders, being flexible and so on. Time is also an ever scarcer resource and, to be innovative, speed in implementation must be central, though without compromising design quality.

Productivity in project management under uncertainty requires excellent management of the information flows. If innovation is a

\section{If innovation is a production process, then information and ideas are the raw materials.}

Innovation inevitably starts with creativity. Many of us have some creativity and it is the organisation's role to provide an environment where we dare to be creative. There are tools that can help us achieve this and break out of set patterns. We know that exposure to information can stimulate creativity, for instance, though information overload can stifle it. Rewards and recognition can help, as can identifying role models for people to follow. Pressure also renders us more creative, as long as escape vents are provided along the way.

Innovation is essentially an "enterprise of the enterprise": it is a risky effort that must be borne by the whole organisation. This organisational integration is a key concept for innovation. A lot has been written on the different ways of organising: one can be production process, then information and ideas are the raw materials to be transformed into (better) goods or services. Access to good quality raw material is paramount. This may mean bringing people together in the same physical space. Though banks and financiers still often band together, for instance, internationalisation has made such centralising more elusive, despite the advantages of proximity. But global networks offer other benefits in terms of ideas and tapping expertise. In today's world, marketers in Europe will collaborate with software designers in India, production plants in China and suppliers in the United States. Learning how to manage these geographically dispersed teams through a better use of IT is a major challenge, since playing too locally can cut you off from potential collaborators, whereas spreading out too finely can erode your influence and could cause you to lose your product to someone else.

Once you have executed your idea and produced your good, you will expect to reap the reward of your efforts, right? Well, it is not quite that simple. Again, you must be organised. Free markets are all very well, but intellectual capital is vulnerable. You will need to protect your innovative ideas. Patents or copyrights might not be enough. Let us be realistic. In many cases and countries the value of these legal tools is limited and enforcing them is expensive and wastes valuable time. After all, can you really prove you have been plagiarised, or that your idea was the original one? There are simple tools and techniques to consider: trade secrets, brands, monopolising resources, captive markets, speed to development, etc. It is wise not to depend on any one of these, but a combination would offer fairly good protection.

Last but not least in this list of categories is the market. This is by no means an afterthought. It is my conviction that highclass communication with the customer, the user, the citizen or anybody who influences buying decisions throughout the whole innovation process is absolutely fundamental to success. Lose contact with the clients and your magnificent breakthrough will be doomed. Call it marketing. In a competitive world where complete originality and genius are rare, good marketing is the innovator's most important weapon for success.

Innovation is good for your health. Manage it and look after it properly. Even if your specific innovation does not change the world, keeping these eight categories high in mind could help you transform your organisation from a mere business into a thriving enterprise.

* Arnoud De Meyer has published widely in the field of Technology Management and Innovation and has contributed to the start up of several entrepreneurial ventures.

\section{References}

- For more on INSEAD: http://www.insead.edw

- OECD (2004), Patents and Innovation: Trends and Policy Challenges, Paris.

- See OECD work on innovation at: www.oecd.org/sti/innovation/ 


\section{Want to Improve Your}

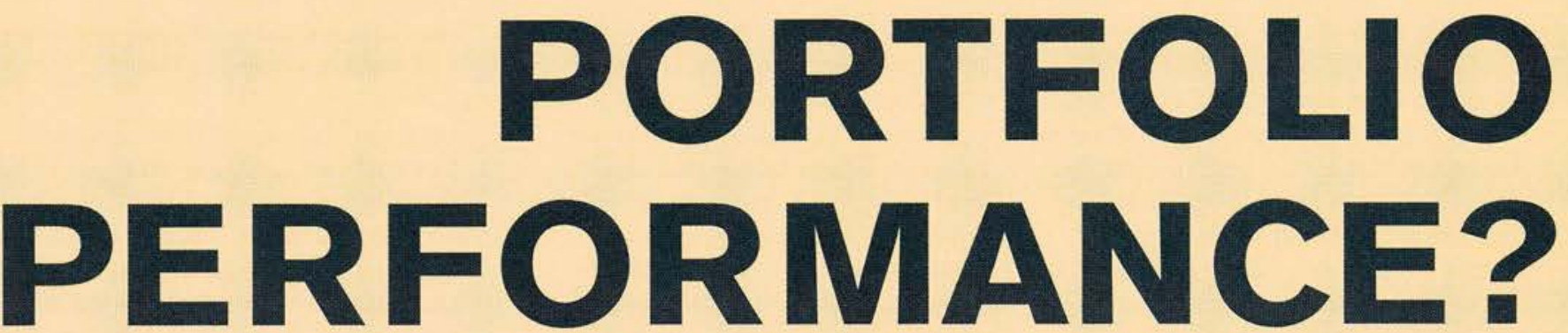

Five separately bookable courses for the investment industry

ESSENTIALS OF PORTFOLIO MANAGEMENT
3rd - 5th May 2004, Dubai ADVANCED PORTFOLIO MANAGEMENT 8th - 12th May 2004, Dubai

ESSENTIALS OF PORTFOLIO MANAGEMENT 17th - 19th May 2004, New York

ESSENTIALS OF PORTFOLIO MANAGEMENT 7th - 9th July 2004, London

PORTFOLIO MANAGEMENT ACADEMY 12th - 23rd July 2004, London 


\section{Learning about teaching}

Education ministers meeting

"Raising the Quality of Learning for All"

18-19 March, Dublin, Ireland

"The never-ending search for competitive advantage in the global knowledge economy has led all public policymakers to focus on education as a key factor in strengthening competitiveness,

employment and social cohesion." This was how Noel Dempsey, Ireland's minister for education and science, summed up the importance of education at a lively meeting of OECD education ministers in Dublin in March.

There was broad agreement at the meeting that better monitoring of educational standards and a broader measurement of educational success were key to progress. But the question of how rustled up some debate. Standard-setting provided one area of contention. Does national testing serve more to narrow curricula than to promote progress?

Education is also a tool for building social cohesion. "Getting the balance right between the needs of the economy and the wider social aims of education systems is one of the most significant challenges facing education policymakers over the next 10 years," Mr Dempsey noted.

But it was the question of teachers which perhaps aroused the most interest at the meeting. Teacher shortages are widespread, while an ageing workforce and a failure to attract the most qualified candidates to the profession, particularly in subjects like maths and science, continue to challenge policymakers. Solutions like flexible career paths to teaching, enhanced by lifelong learning for teachers, were discussed, as was how to improve conditions and support for new teachers.

Clearly, the image of teachers could use a boost. The ministers noted that it was often those who came into contact with teachers most who had the highest regard for them, and stressed the importance of strengthening school-community links.

\section{Global warning}

Environment ministers meeting 20-21 April 2004

Three years after the adoption of the OECD 10-year Environmental Strategy, ministers acknowledged that they are "not on track" for implementing it by 2010 and that more ambitious action is needed. OECD and nonOECD ministers or deputy-ministers met in Paris to assess progress.

Martin Cullen, the meeting's Chair and the Irish minister for the environment, heritage and local government, acknowledged that Ireland itself has much work to do, particularly in the area of global warming. He reaffirmed that his country was determined to meet its goals and urged other countries to adopt a similar strong commitment.

This high-level conference served as a wakeup call. It was the first time ever at the OECD that representatives from business, trade unions and environmental NGOs took part in the ministerial meeting itself, and not just through prior consultations.
Serious environmental challenges remain, ministers agreed, particularly in reducing greenhouse gas emissions, halting biodiversity loss, and decoupling environmental pressures from economic growth. Ministers voiced a sense of urgency on the need to tackle climate change. Only one in three OECD countries have managed to stabilise or reduce their greenhouse gas emissions, and Minister Cullen urged all members to ratify and implement the Kyoto Protocol as soon as possible.

Further progress could also be achieved by developing so-called "market-based" policies such as tradable permits, ministers agreed. They questioned environmentally harmful subsidies, including tax exemptions, which distort trade, and agreed to make reform and the costs of inaction an important focus of OECD work. The role of the private sector was key, the conference agreed, and applying cleaner technologies would also need to play a stronger role in addressing environmental challenges.

Ministers adopted a Statement for further work on sustainable development and agreed to meet again for a second interim review in 2008 .

The Chinese vice-minister for the environment took the opportunity to

\section{Hungary and Poland visit}

Four OECD countries - the Czech Republic, Hungary, Poland and the Slovak Republic - are among the 10 new members that joined the EU on 1 May. Government leaders from two of these recently visited the OECD: the prime minister of Hungary, Péter Medgyessy, on 8 April, and on 22 April, Poland's foreign minister, Wlodzimierz Cimoszewicz.

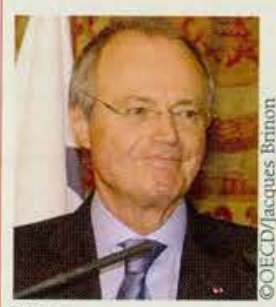

Péter Medgyessy

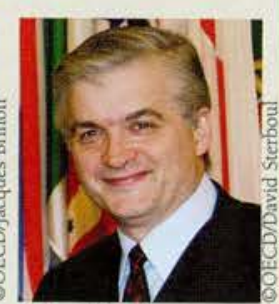

Wlodzimierz Cimoszewicz announce that the OECD will undertake an Environmental Performance Review of China in 2005

- For more, including a full summary from the chair: www.oecd.org/envmin2004 


\section{Calendar of forthcoming events}

Please note that many of the meetings mentioned are not open to the public or media and are listed as a guide only. All meetings are in Paris unless otherwise stated. For further information, consult the OECD website at www.oecd.org, under "Key upcoming events", which is updated weekly.

MAY

Small and Medium Enterprises, Clusters and Poverty Lessons from India, informal seminar organised by the OECD Development Centre.

11 OECD Economic Outlook $N^{\circ} 75$ published.

12-13 OECD Forum 2004: Health of Nations, annual public gathering of leaders from government, business, academia and civil society, organised by the Public Affairs and Communications Directorate (PAC).

13-14 Meeting of OECD health ministers: Towards High Performing Health Systems.

13-14 OECD Council meets at ministerial level.

14 Financial Action Task Force meets at ministerial level.

17-18 Highly-Skilled Workers and Economic Performance, workshop organised by the Directorate for Science Technology and Industry (STI). Stockholm, Sweden.

18-19 Institutional Approaches to Policy Coherence for Development, workshop organised by the Development Assistance Committee.

24 African Economic Outlook, annual report launched. Kampala, Uganda.

26-27 European Conference of Ministers of Transport (ECMT) meets at ministerial level. Ljubljana, Republic of Slovenia.

27-28 High-level meeting on shipbuilding, organised by STI.

27-28 Saving Energy in Set-Top Boxes, workshop organised by the International Energy Agency (IEA).

JUNE

3-4 Corporate Governance and Economic Growth in Russia, conference organised by the Russian National Council on Corporate Governance with the support of the World Bank and the OECD. Moscow, Russia.

3-5 Promoting Entrepreneurship and Innovative SMEs in a Global Economy, second OECD conference of ministers, organised by STI and the Turkish government. Istanbul, Turkey.

8-10 Sea Island Summit, annual meeting of the G8 leaders. Sea Island, Georgia, US.

13-18 UNCTAD XI, UN Conference on Trade and Development. Sao Paulo, Brazil.

14-15 Latin American Competition Forum, jointly organised by the Directorate for Financial and Enterprise Affairs (DAF) and the Inter-American Development Bank (IDB). Washington DC, US.

16 Skills Upgrading, conference organised by the Directorate for Employment, Labour and Social Affairs (ELS). Copenhagen, Denmark.

20-22 Tidewater meeting of development ministers. Massachusetts, US.

23-24 Third German Corporate Governance Code conference, organised by the Commission of the German Corporate Governance Code. Berlin, Germany.

23-25 Ministerial conference on environment and health: The Future for our Children, organised by the World Health Organization (WHO). Budapest, Hungary.

24-25 European ministers of education meet to discuss "Investing in Lifelong Learning and Giving Europe a Competitive Advantage: From Rhetoric to Reality". Oslo, Norway.

29 International Risk Governance Council, inaugural conference, held at the World Meteorological Organisation. Geneva, Switzerland.

JULY

5-9 Environmental Culture Week, with OECD patronage. Genoa, Italy.

8-9 Tackling Regulatory Reform and Corruption, ministerial meeting organised by the Investment Compact for South-Eastern Europe and DAF. Vienna, Austria.

12-13 International Network of Pension Regulators and Supervisors (INPRS), annual conference organised by DAF:

15-16 Global Science Forum, meeting organised by STI.

\section{AUGUST}

26-28 Global Demographic Change: Economic Impacts and Policy Challenges, 28th Economic Policy Symposium of the Federal Reserve Bank of Kansas City. Jackson Hole, Wyoming, USA. 
-MDM.FINANCIAL.GROUP.

\section{The Banker}

THE SECOND ANNUAL CONFERENCE

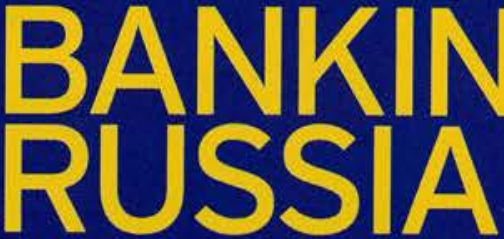

Opportunities and challenges for inward investment



$$
\text { inward investment }
$$

\section{MAY 2004, CLARIDGE'S, LONDON ONE DAY CONFERENCE}

This hugely successful event is to be repeated in 2004 . Those who attended in 2003 will recall that it is an event to be scheduled into the diary.

By attending this briefing, delegates will be able to:

- EXPLORE the political and economic development prospects for Russia in 2004/2005

DISCOVER strategies for raising finance and understand the structure of the Russian equity market

- APPRAISE emerging investment opportunities for companies and banks and hear the latest news on the restructuring and privatisation of the Russian Banking Sector

> CAPITALISE on expanding retail banking opportunities and the development of the mortgage market in Russia

\section{EASY WAYS TO REGISTER}

Call: $+44(0) 2073828273$

B Fax: $+44(0) 2073828544$

\section{QUOTE REF: BRU2}

E-mail: finance.event@ft.com

a ww.ftbusinessevents.com
SPEAKERS INCLUDE:

RICHARD SPIKERMAN Chaiman of the SUpervisory Board, MDM Holding GmbH GAREGIN TOSUNYAN Phesident,

Association of Russian Banks

JEFFREY COSTELLO CEO Bninswick UBS Warburg

PAUL FORREST Group Economist, Moscow Narodny Bank PAVEL GOURINE Member of the Board and Head of Corporate Finanoe \& Investment Banking Raiffeisen Bank Austria ZAD

ALEXANDER LEVKOVSKIY President, Promsuyazbank NANDAN MER Head of Retail Banking Cifgroup DMIRY MOKHNACHEV Member of the Board, intemational Moscow Bank

POUL THOMSEN Senior Resident Representative, IMF DMITRI V. CHIBISOV Director, Project Finanoe Department, GLOBEXBANK

ADRIAN WALKER Head of Syndications, Standard Bank KURT GEIGER Head of the Financial

Instlutions Group, EBRD

ALEXANDER KOTCHERGUINE EXECutive Dirrector,

MDM Financial Group

PAUL WLLEN Business Group Manager Vanilla Debt

EMEA Bank of New York

EVGENY YAROVIKOV Head of Financial Institutions Rosbank EMMANUEL VOLLAND Director - Financial Services Redings Standard \& Poor's

MARCIA TARTER Managing Director, Head of CEEMEA

Corporate Bond Pesearch, UBS

WHO SHOULD ATTEND?

- Asset Managers

- General Managers of Commercial Banks

- Finance Directors in banks and corporations

Arrangers, Lead Managers, Heads of Fixed

Income \& Capital Raising

Regional Heads for CEE

- Credit Analysts

Banking Analysts

- Rating Agencies

Entry is granted at the discretion of the publisher. 


\section{Developing trust}

Corporate Governance in Development: The Experiences of Brazil, Chile, India, and South Africa

We all now know that weak corporate governance can have a real impact on investors, savers, retirees, creditors, employees and consumers, as well as on entire economies. Corporate failures from the US to Italy have demonstrated this. But what would the effects be on developing countries?

Significant, according to Corporate Governance in Development. The report highlights the institutional characteristics of developing countries that tend to impede the transparency, accountability and enforcement needed to implement effective corporate governance.

Four countries are examined in detail - Brazil, Chile, India and South Africa - addressing the corporate governance challenges they all face towards achieving long-term development.

\section{In OECD countries, the} interest in corporate governance has grown in conjunction with globalisation, as well as with the growth of cross-border portfolio investment. In light of this, the OECD's recently revised Principles of Corporate Governance (see article by Bill Witherell, page 41) aim to improve not only corporate accountability, but also the legal, institutional and regulatory framework for corporate governance around the world.

\section{Corporate Governance in} Development stresses that development is closely associated with the need for adequate corporate governance enforcement measures - judicial and regulatory - and a simultaneous shift in political governance, one of the greatest challenges facing developing countries today.

Corporate governance is central to increasing the flow and lowering the cost of financial capital in both developed and developing countries alike. Its importance is further warranted as corporations' needs for new sources of financing expand. As Corporate Governance in Development highlights, this is no less true in developing countries, where a gap is being left from the retrenchment of statesponsored financing. This means more private investment, both domestic and from abroad. But financiers and shareholders are increasingly demanding better boardroom behaviour. Better corporate governance improves credibility and gives companies a chance not only to attract investment, but to hold on to it in the long run. That means the economic stability which development depends on.

\section{Prevention or cure}

\section{A Development Co-operation}

Lens on Terrorism Prevention

Violent conflict plus

widespread public insecurity and fear are primary causes of poverty, says the OECD's Development Assistance Committee. Yet poverty itself is fertile ground for terrorism. In fact, terrorists often cite development problems as justification for their acts, says A Development Cooperation Lens on Terrorism Prevention.

This booklet focuses on ways that aid donors can follow to address the links between terrorism and development, and suggests how aid programmes may be designed or adjusted accordingly, on both financial and social levels. While development efforts cannot and should not target individual terrorists or their networks, warns A Development Co-operation Lens on Terrorism Prevention, donor countries have a role to play in helping to deprive terrorists of the conditions that they feed on and exploit.

Bolstering stability with funding programmes is just one element. Within the framework of providing aid, efforts need to be made also at the community level to dissuade disaffected groups from embracing violence, reinforce good governance and make globalisation an inclusive process.

For instance, interviews with terrorists from Christian, Hindu, Jewish and Muslim groups reveal that religion is often used as a vehicle to

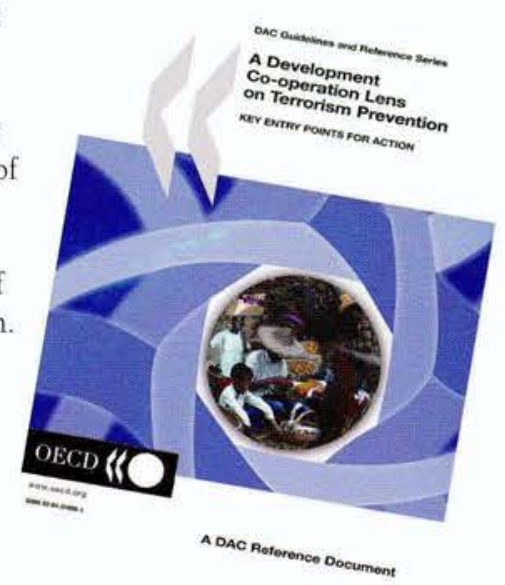

articulate political and economic grievances. A Development Co-operation Lens on Terrorism Prevention advises that donors should work with local religious groups to better understand belief systems and avoid eschewing them. In particular, the report says, it is important to help build bridges between religious and cultural communities so that the process of "secular" modernisation of the State does not destroy these vital connections.

Though some renowned terrorists are themselves wealthy, living a quite privileged existence, they win adherents when they argue that there is little to live for in their "impoverished" world and more to look forward to in the next. Economic development might not stop extremists, but can help make recruiting grounds much less fertile (see article by Richard Manning, page 36)

- A Development Co-operation Lens on Terrorism Prevention can be downloaded free at www.oecd.org/dac/conflict/ 


\section{On the right track}

\author{
Regulatory Reform of \\ Russian Railways
}

Russia is on a fast track to reform its transport system, reports Regulatory Reform of Russian Railways. While the Trans-Siberian highway from Moscow to Vladivostok - the longest road in the world at nearly 10,000 kilometres - had its final gaps filled in as of March this year, it will not be completely paved before 2008. Russians' preferred mode of transport remains the train, and the Trans-Siberian railway, the world's longest continuous railway line, was completely electrified just under two years ago.

In 2003, the government restructured the controlling body of the railway system, called the Ministry of the Means of Communication, dividing it up into several components that include a new ministry and a railway operating division, Russian Railways. Ongoing reforms call for adjusting the tariff system and promoting competition, primarily by encouraging industry to transport its own goods on the existing infrastructure of over $149,000 \mathrm{kms}$ of track. With general ageing and a national shortage of rail cars, the government has introduced new tariff schedules for operators with their own wagons and locomotives to encourage them to build up their own fleets. Since rail

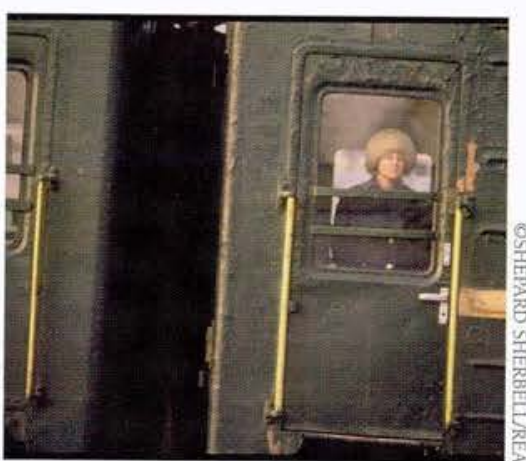

Is she? carries over $80 \%$ of Russia's freight traffic, the market will also open up for facilities such as stations, freight yards and train marshalling services.

Passenger operations will be separated into entities that might eventually be spun off to regional or local governments, or even privatised, says Regulatory Reform of Russian Railways. Suburban services operate at a loss in Russia, as they do in most OECD countries. Presently, these short-haul passenger services are subsidised from rail-carried freight revenues.

But if the roads keep improving and car sales keep growing, Russian truckers could put even this income at risk. Competition from road haulage is increasingly limiting the market power of freight trains in European Russia, although rail still holds a near monopoly on freight transport east of the Urals. The government will remain under pressure to keep rail reforms rolling at a good pace.

\section{Government and nuclear energy}

\section{Government and Nuclear Energy}

Nuclear energy generation has come a long way since the first large-scale nuclear power plant flipped the switch in Shippingport, Pennsylvania in

December 1957. Today, nuclear energy generates about $16 \%$ of the world's electricity.

In the current context of privatisation and deregulation of the electricity sector, the role of governments continues to evolve, as do the tools they have at their disposal to implement national policies. Government and Nuclear Energy reviews issues raised by this evolution in the nuclear industry sector, with emphasis on the key responsibilities of governments with regard to security of energy supply, health and environmental protection and, more generally, the implementation of sustainable development policy.

\section{Governments have been} directly involved in the development of nuclear energy since its inception, primarily for the generation of electricity. In the second half of the 20th century, the reconstruction and economic growth in OECD countries were driven by the implementation of large national projects leading to the establishment of industrial infrastructures, including electricity generation and transmission networks, Government and Nuclear Energy reviews how nuclear energy, partly because of its science and technology applications, benefited from government support in R\&D to facilitate its development.

Governments have specific responsibilities in the field of nuclear energy, covering nuclear safety, radiological protection, legal infrastructure and nonproliferation of nuclear weapons. In this area, Government and Nuclear Energy argues that the role of government has not evolved drastically, but that privatisation of the industry and market deregulation have an impact on the regulatory approaches taken by governments in pursuit of their policy goals.

Government and Nuclear Energy highlights key responsibilities of governments in the field of internalising external costs and ensuring that market prices reflect the full benefits and cost to society of products and services. It covers a wide range of issues of relevance to policymakers, irrespective of the national position towards nuclear energy. 


\section{New publications, April - June 2004}

All publications are available in paper and electronic book format. This is a selected list. For more titles and overviews in different languages, please consult www.oecd.org/bookshop.

OECD Annual Report:

2004 Edition

ISBN: 9264019715

130p

Free publication.

\section{AGRICULTURE AND FOOD}

Rural Finance and Credit Infrastructure in China

ISBN: 9264015280

389 p, 60 tables

€70 $\$ 88 £ 49 ¥ 9,000$ MXN900

Review of Fisheries in OECD Countries: Country Statistics 2000-2002

ISBN: 9264020438

$250 p, 250$ tables

$660 \quad \$ 75 \quad\{42 \quad \ngtr 8,200$ MXN710

Agriculture, Trade and the Environment: The Dairy Sector ISBN: 9264015884

210p, 40 tables, 26 graphics

Prices forthcoming.

\section{Abstracts of Agricultural}

Tractor Tests

Co-edited with CEMAGREF

ISBN: 2853626334

$320 \mathrm{p}$

$€ 40 \quad \$ 50 \quad £ 28$ Y5,100 MXN510

The OECD Standard Code for testing of agricultural and forestry tractors defines rules enabling 30 official centres in 28 countries to produce comparable results. Since 1959 more than 1,700 tractors have been tested

\section{DEVELOPMENT AND AID}

The Making of Global Finance 1880-1913

ISBN: 9264015345

152 p, 52 tables, 14 graphics

$£ 24 \$ 30 \quad £ 17 \quad ¥ 3,100$ MXN310

Institutional Efficiency and its Determinants: The Role of Political Factors in Economic Growth

ISBN: $926410643 \mathrm{X}$

$104 \mathrm{p}$

$€ 24 \$ 30 \_17$ Y3,300 MXN290

At a time when national governments and international institutions are seeking ways to improve governance and accelerate growth, particularly in the poorer countries, this book offers convincing evidence about the quality of institutions as a determining factor in development.
Towards a Better Regional

- Approach to Development in West Africa

ISBN: 9264198296

$148 \mathrm{p}$

$€ 35 \$ 35 \quad\{22 \quad ¥ 4,100$ MXN320

\section{ECONOMICS}

- Understanding Economic Growth: A Macro-level, Industry-level and Firm-level Perspective Co-edited with Palgrave Macmillan Ltd ISBN: 1403941475

200p, 25 tables, 29 graphics

$€ 19 \$ 24 \quad\{13 \$ 2,600$ MXN220

J See review.

The Emerging Security Economy:

What Trade-offs in an Open and

Mobile Society?

ISBN: $926410772 \mathrm{X}$

130p, 20 graphics

$€ 24 \$ 30 \_17 \times 3,100$ MXN310

How large are the potential economic costs of major disruptions to transport systems and information networks? What is the overall cost of tighter security? Are there trade-offs between higher levels of security and economic efficiency?

OECD Economic Outlook No. 75 ב OECD Code 122004751P1

256,67 graphics

E61 $561 \quad\{39 ¥ 7,500$ MXN630

\section{OECD ECONOMIC SURVEYS}

Each survey: $€ 35 \$ 37 \quad\{23 \quad ¥ 4,600$ MXN 450

United States

ISBN: 9264015787

- 100p, 17 tables, 29 graphics

Special feature: Competition and

economic performance.

Slovak Republic

ISBN: 9264020268

166p, 31 tables, 64 graphics

」 Special feature: Rationalising public spending.

Netherlands

$175 p, 38$ tables, 47 graphics

United Kingdom

ISBN: 9264020225

228p, 33 tables, 93 graphics

Special feature: Product market competition and economic performance.

Watch out for these forthcoming OECD publications

- Information Technology Outlook (May 2004)

Benefits and Wages 2004 (June 2004)

- Economic Survey: Korea (June 2004)

- Agricultural Policies in OECD Countries: At a Glance (June 2004)

] OECD Agricultural Outlook: 2004/2009 (July 2004)

] OECD Employment Outlook (July 2004)

\section{EDUCATION}

Key Trends and Issues in Crossborder Post-Secondary Education $\square$ ISBN: 9264015043

$250 \mathrm{p}, 50$ tables, 15 graphics

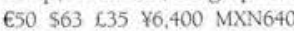

What are the issues, and what factors contribute to the growth of cross-border education, including student mobility, but also mobility of programmes and institutions.

Quality and Recognition in Higher Education across Borders

ISBN: 9264015086

$150 \mathrm{p}$

$630 \$ 38$ f21 ¥3,800 MXN380

Higher Education Management and Policy: Volume 16 Issue 1

OECD Code 892004011P1

$144 p$

Sold as subscription only

OECD Survey of Upper Secondary Schools: Technical Report ISBN: 9264105727

$132 \mathrm{p}$

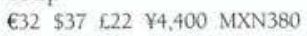

\lrcorner$\overline{\text { EMPLOYMENT AND SOCIAL }}$ ISSUES

Global Knowledge Flows and Economic Development

ISBN: 9264107665

- $146 \mathrm{p}, 8$ tables

$€ 30 \$ 38 \quad \ldots 21 ¥ 3,800$ MXN380

Reforming Public Pensions:

Sharing the Experiences of

Transition and OECD Countries

ISBN: 9264105808

$344 \mathrm{p}$

€70 $\$ 81 \quad\{, 49 \ngtr 9,600$ MXN830

a Ageing and Employment Policies: Japan

ISBN: 9264021094

$148 \mathrm{p}$

$€ 24 \$ 24 \quad .15 \quad \times 2,900$ MXN250

\section{ENERGY}

Oil Crises and Climate Challenges: 30 Years of Energy Use in IEA Countries

ISBN: 9264018824

$216 \mathrm{p}$

$€ 100 \$ 100 \quad 567 \ngtr 12.800$ MXN1.150

The History of the International Energy Agency: Volume 4

ISBN: 9264014934

$352 \mathrm{p}$

675 \$94 £52 ¥9,600 MXN960

Government and Nuclear Energy $]$ ISBN: 9264015388

96p

$€ 21 \$ 26 \quad € 15 \quad \$ 2,700$ MXN270

See review.

The Regulatory Control of Radioactive Waste Management: Overview of 15 NEA Member Countries

ISBN: 9264106502

$212 \mathrm{p}$

E50 $\$ 63 \quad 635 \quad \% 6,400$ MXN640

An array of facts, for 15 NEA member countries, about national policies for radioactive waste management, legislative and regulatory frameworks, classification and sources of waste and the status of waste management.

Nuclear Legislation in Central and Eastern Europe and the NIS: 2003 Overview ISBN: 9264015426

216p, 30 graphics

E48 \$60 £33 ¥6,100 MXN610

\section{ENVIRONMENT}

OECD Environmental Strategy:

2004 Review of Progress

ISBN: 9264107800

156p, 13 tables, 12 graphics

$€ 40 \$ 50 \lcm{228} \$ 5,100$ MXN510 
In 2001, OECD environment ministers agreed on an ambitious Environmental Strategy for the first decade of the 21 st century. This report assesses the progress that $\mathrm{OECD}$ countries have made and highlights the challenges and obstacles that remain if countries are to achieve the objectives by 2010 .

\section{Tradeable Permits: Policy \\ Evaluation, Design \\ and Reform \\ ISBN: 9264015027 \\ 183 p, 23 tables, 23 graphics \\ $\epsilon 40 \$ 50 \quad 228 \times 5,100$ MXN510}

OECD Environmental Performance

Reviews: Canada

ISBN: 9264107762

164 p, 25 tables, 21 graphics

$€ 37 \$ 377 \quad 624 \quad \% 4,500$ MXN380

\section{FINANCIAL AND}

\section{ENTERPRISE AFFAIRS}

Insurance Regulation and Supervision in Latin America: A Comparative Assessment ISBN: 9264104453

$124 \mathrm{p}$

E45 $\$ 52 \quad 230 \quad 75,700$ MXN520

OECD Investment Policy Reviews: Caribbean Rim: Costa Rica,

Dominican Republic and Jamaica ISBN: 9264105093

188 p, 53 tables

E35 $\$ 40 \quad £ 25 \quad ¥ 4,800 \quad \mathrm{MXN} 420$

Factual assessments of investment conditions, of interest to those concerned with the development of investment opportunities in the region These reports are intended to be used as a roadmap for developing and implementing investment policy reform.

External Debt Statistics: Guide for Compilers and Users

Co-edited with the International Monetary Fund (IMF)

ISBN: 1589060601

309p

See: http://www.imf.org/external/ pubs/ft/eds/Eng/Guide/index.htm

Pension Reform in the Baltic

Countries

ISBN: 9264021051

$266 \mathrm{p}$

E50 $\$ 63$ E35 $¥ 6,400$ MXN640

\section{GOVERNANCE}

Corporate Governance: A Survey of OECD Countries

ISBN: 9264106057

$72 \mathrm{p}$

E21 \$24 $\$ 15 \quad ¥ 2,900$ MXN250

This survey examines the systemic issues at the forefront of the corporate governance debate and discusses how
OECD countries have responded. It offers a rich variety of experiences and confirms the relevance of the OECD Principles of Corporate Governance.

Corporate Governance in

Development: The Experiences of

Brazil, Chile, India, and South

Africa

Co-edited with the Centre for International Private Enterprise (CIPE)

ISBN: 9264106588

242p

$€ 21 \$ 26 £ 15 \quad$ \$2,700 MXN270

See review.

OECD Reviews of Regulatory Reform

Germany: A Necessary Element of Economic and Social Renewal

ISBN: 9264107843

$176 \mathrm{p}, 12$ tables, 18 graphics

E40 \$46 £27 ₹5,100 MXN460

Regulatory Reform in France:

Charting a Clearer Way Forward $\square$

ISBN: 9264015469

$156 \mathrm{p}, 12$ tables, 10 graphics

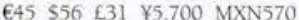

\section{HEALTH}

Towards High-Performing Health Systems

ISBN: 9264015558

$90 \mathrm{p}, 18$ graphics

$€ 21 \$ 26 \quad f 15 \quad ¥ 2,700$ MXN270

Towards High-Performing Health Systems: Policy Studies

ISBN: 9264015590

300p, 55 tables, 56 graphics

Prices forthcoming.

Analytical findings, supporting data and policy implications on such key policy issues as quality of health care, equity of health service use, human resources issues, private health insurance, and spending projections, with lessons from health-system reforms in OECD countries over the past several decades.

Private Health Insurance in OECD Countries: The OECD Health

Project

ISBN: 9264016639

230p, 35 tables, 25 graphics

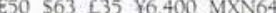

Health Technologies and

Decision Making

OECD Code 922004081P1

140p, 25 tables, 12 graphics

Prices forthcoming

Long-Term Care for Older People:

Policy Issues for the 21st Century

ISBN: 9264015841

$120 \mathrm{p}$

Prices forthcoming

OECD Health Data 2004

ISBN: 9264106480

For-profit $€ 325 \$ 406 \notin 225 ¥ 41,800$ MXN4,150
Not-for-profit: $\quad$ 2225 $\quad \$ 281 \quad 6156 \quad \$ 28,900$ MXN2,900

CD-ROM, CREDES software.

\section{INDUSTRY, SCIENCE AND}

INNOVATION

Space 2030: Exploring the Future of Space Applications

ISBN: 9264020322

194p, 22 tables, 72 graphics

$€ 35 \$ 44 \quad 524 \quad ¥ 4,500 \mathrm{MXN450}$

Information Technology Outlook:

ICTs and the Information

Economy

300p, 125 tables, 146 graphics

Prices forthcoming

The Economic Impact of ICT:

Measurement, Evidence and

Implications

ISBN: 9264021035

$304 p, 72$ tables, 58 graphics

E65 $\$ 81 \quad\{45 \quad 78,300$ MXN830

How precisely does ICT affect economic growth and the efficiency of firms? And how well can these effects be measured?

\section{STATISTICS}

Accounting Frameworks to

Measure and Analyse Sustainable

Development

ISBN: 9264020128

$521 \mathrm{p}, 92$ tables, 94 graphics

E90 $\$ 104 \quad[63 \quad ¥ 12,300$ MXN1,080

$\sqsupset$ Central Government Debt:

Statistical Yearbook 1993-2002

ISBN: 9264015728

$430 \mathrm{p}, 150$ tables

$680 \$ 100$ E55 $¥ 10,300$ MXN1,020

Also available online.

OECD Statistics on International

Trade in Services: Volume

Co-edited with EUROSTAT

ISBN: 9264015507

$428 \mathrm{p}, 233$ tables

$€ 95 \$ 119$ E66 $¥ 12,200 \mathrm{MXN1}, 200$

Also available on CD-ROM and online.

\section{SUSTAINABLE}

DEVELOPMENT

Assessment and Decision Making for Sustainable Transport

- ISBN: 9282113116

234p

$655 \$ 69 \quad 539$ ₹7.500 MXN650

Recommendations for good practice in the transport sector, based on recent experience in infrastructure planning and policy development in seven countries.

Communicating Environmentally Sustainable Transport: The Role of Soft Measures

- ISBN: 9264106634

$183 \mathrm{p}$

€40 \$50 $628 \quad ¥ 5,100$ MXN510

\section{TAXATION}

Taxing Wages: 2002-2003

ISBN: $926401523 \mathrm{X}$

$420 p, 146$ tables, 10 graphics E95 \$119 ₹66 Y12,200 MXN1120

\section{TRANSPORT}

Trends in the Transport Sector: 1970-2002

ISBN: 9282103234

62p. 16 tables, 11 graphics

- $\quad 21 \$ 26 \quad £ 15 \quad \$ 2,700$ MXN270

How have the passenger and freight transport sectors evolved since 1970? How is road safety faring? Provides figures on key transport trends, and analyses the transport situation in the western and eastern European countries, as well as the Baltic States and the CIS

Can Cars Come Clean? Strategies for Low-Emission Vehicles ISBN: $926410495 \mathrm{X}$

208p, 55 tables, 35 graphics €45\$52 £30 \$5,700 MXN520

\section{Regulatory Reform of Russian} Railways

ISBN: $928212309 \mathrm{X}$

179 p, 18 tables, 53 graphics

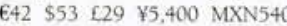

See review.

Keeping Children Safe in Traffic ISBN: 926410629.

$128 \mathrm{p}, 15$ graphics

$€ 30 \$ 38 \quad £ 21 \quad ¥ 3,800 \quad M X N 380$

\section{Latest OECD Policy Briefs}

Free online at www.oecd.org/publications

Economic briefs on Surveys of the United States, Norway, Slovak Republic

- Corporate Governance in Developing, Transition and Emerging-Market Economies

- Raising the Quality of Educational Performance at School

The Quality of the Teaching Workforce

$\square$ Lifelong Learning

Education and Equity

- Public Sector Modernisation

- OECD Environmental Strategy: 2004 Review of Progress

- The OECD Environmental Strategy: Progress in Managing Water Resources

Innovative Approaches to Funding the Millennium Development Goals 


\section{True growth}

Understanding Economic Growth

"The end of World War II marked the beginning of a long period of prosperity in most countries now members of the OECD ... and in many countries per capita incomes tended to catch up with American levels," OECD Chief Economist Jean-Philippe Cotis observes in his foreword to Understanding Economic Growth. Mr Cotis continues: "The history of the past two decades tempered to a great extent that initial enthusiasm. In the major countries of continental Europe, per capita incomes stopped converging towards American levels as of the early 1980s, before falling in relative terms throughout the 1990s. Japan has suffered a similar reversal of fortune during the past 15 years."

What happened? Why did some countries surge ahead, even those that had already reached a high level of innovation and growth, while others lagged behind? Such questions revived the debate over the underlying causes of economic growth, and Understanding Economic Growth is the fruit of the extensive OECD Growth Project.
The analysis focuses on the growth patterns of OECD countries during the last decade and identifies the fundamental drivers of growth, like human capital, $\mathrm{R} \& \mathrm{D}$ and innovation. It also looks at how and why countries respond differently to these drivers. It examines growth at the macroeconomic level, as well as industry and firm level, and analyses the contribution of information technology at each of these levels.

Packed with over 50 tables and figures, Understanding Economic Growth provides unique data to better understand the truth beyond the hype of the so-called new economy. What was the real contribution of IT to economic growth?

According to Mr Cotis, it plays a very important role, albeit one that "does seem to depend a great deal, in turn, on the regulatory and institutional framework in which technological innovation takes place." The study points to empirical evidence that the opening up of product and services markets and the flexibility of the regulatory framework contribute to growth, as well as opening the way for small, highly innovative firms to flourish. But there is no magic formula that bypasses the fundamentals. As Understanding Economic Growth underlines, no one can overlook the contribution that sound macroeconomic policies low and stable inflation, moderate tax burdens, openness to international trade - make to economic growth.

\section{ORDER FORM}

\section{Subscribe to the OECD OBSERVER}

\begin{tabular}{|c|c|c|}
\hline $\begin{array}{l}\text { Yes, please enter my subscription for } \\
\text { six issues plus my free OECD in Figures }\end{array}$ & $\begin{array}{l}\square € 50 \\
\square U S \$ 50\end{array}$ & $\begin{array}{l}\text { Subscription will commence with the next available } \\
\text { issue. Subscribers will be provided with the English } \\
\text { language edition unless otherwise indicated. }\end{array}$ \\
\hline annual supplement, worth $€ 15$. & $\square\{31$ & English language edition (0100001P) ISSN 0029-7054 \\
\hline & $\square ¥ 5,900$ & J French language edition (0100002P) ISSN 0304-3398 \\
\hline
\end{tabular}

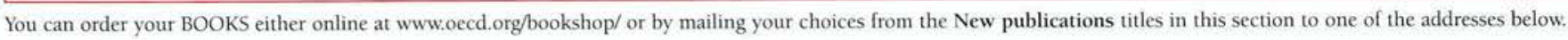
Where do we deliver?

Name.

Organisation

Position held

Address

Postcode

City

E-mail.

\section{Payment details}

D Cheque/money order enclosed (payable to OECD)

D Please charge my VISA/MasterCard/American Express

TOTAL amount due .

Card Expiry Date.

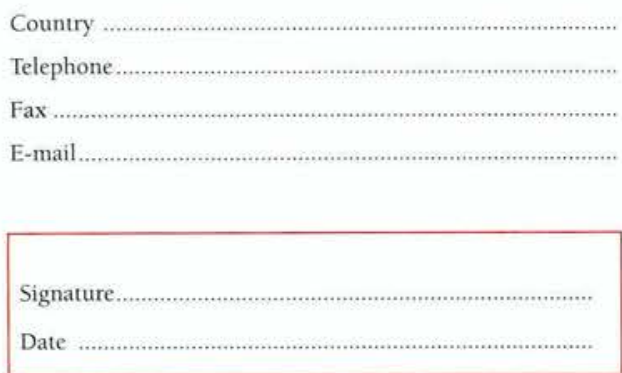

Card number
For customers in Latin America OECD MEXICO Centre

For customers in Asia OECD TOKYO Centre 3rd Floor, Nippon Press Ctr. Bldg Av. Presidente Mazaryk 526 2-2-1 Uchisaiwaicho, Chiyoda-ku Colonia: Polanco C. P.11560 TOKYO 100-0011, JAPAN

Tel: (81-3) 55320021 Fax: (81-3) 55320035

E-mail: center@oecdtokyo.org Internet: www oecdtokyo.org
MEXICO D.F, MEXICO

Tel: $(52-55) 52813810$

Fax: (52-55) 52800480

E-mail: mexico.contact@oecd.org

Internet: rn.net.mx/ocde/
For customers in the United States OECD Distribution Center c/o Extenza-Turpin 56 Industrial Park Drive Pembroke, MA 02359, USA Toll free: (1-800) 4566323 Tel.: (1-781) 8267572

Fax: (1-781) 8299052

Email:OECDNA@extenza-turpin.com Internet: www.oecdwash.org
For customers in the rest of the world OECD c/o Turpin Distribution Services Ltd.

Stratton Business Park, Pegasus Drive, Biggleswade, Bedfordshire, SG18 8QB, UK Fax: (44)1767 601640

E-mail: books@extenza-turpin.com E-mail:

subscriptions@extenza-turpin.com 


\section{Healthier energy use}

W hile energy demand in IEA countries has increased steadily since 1973, with only two interruptions, energy savings have been substantial, according to Oil Crises and Climate Challenges: 30 Years of Energy Use in IEA Countries. Compared to 1973, it takes a third less energy to produce a unit of GDP, thanks in part to improved energy efficiency.

This energy end-use intensity for the IEA-11 countries* declined by as much as $2.5 \%$ per year on average between 1973 and 1982. Over the next eight years, the decline was still significant, although at a somewhat lower average rate of 1.5\% annually. After 1990, the average rate was down to only $0.7 \%$ per year.

Energy-saving has lost momentum most prominently in manufacturing, where the average annual rate of decline was a strong $3.5 \%$ between 1973 and 1986 , yet only $0.6 \%$ per year for the 12 years that followed.

Without these 25 years of energy savings, energy consumption would have been almost $50 \%$ higher, Over the same period, $\mathrm{CO}_{2}$ emissions declined or grew only modestly in most countries. In the IEA as a whole, $\mathrm{CO}_{2}$ emissions in 1973 were just under 1990 levels. Yet after 1990, many countries saw emissions increase significantly as prices eased and demand surged. Furthermore, in

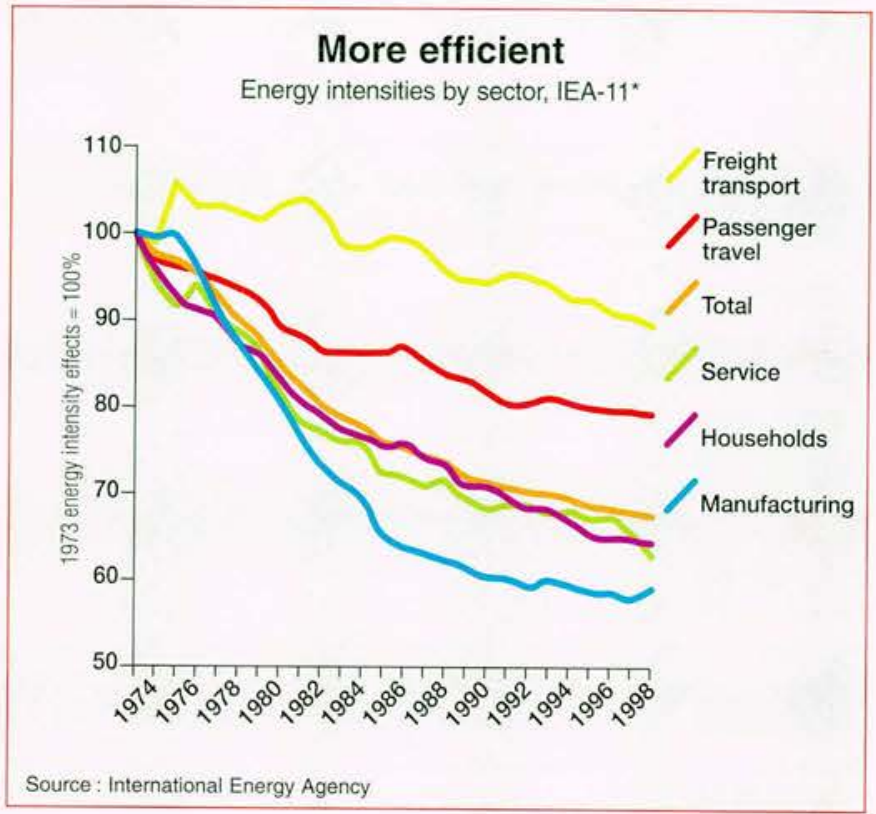

the EU the annual growth in emissions between 1998 and 2001 was stronger than over the previous eight years.

* IEA countries for which complete time series are available: Australia, Denmark, Finland, France, Germany, Japan, Italy, Norway, Sweden, UK and US.

\section{Nanotech is not small}

Tanotechnology R\&D continues to grow in priority on national 1 science agendas in OECD countries, both in terms of public and private funding. The United States, Europe and Japan each spend between US\$500 million and $\$ 1$ billion a year on nanotechnology R\&D.

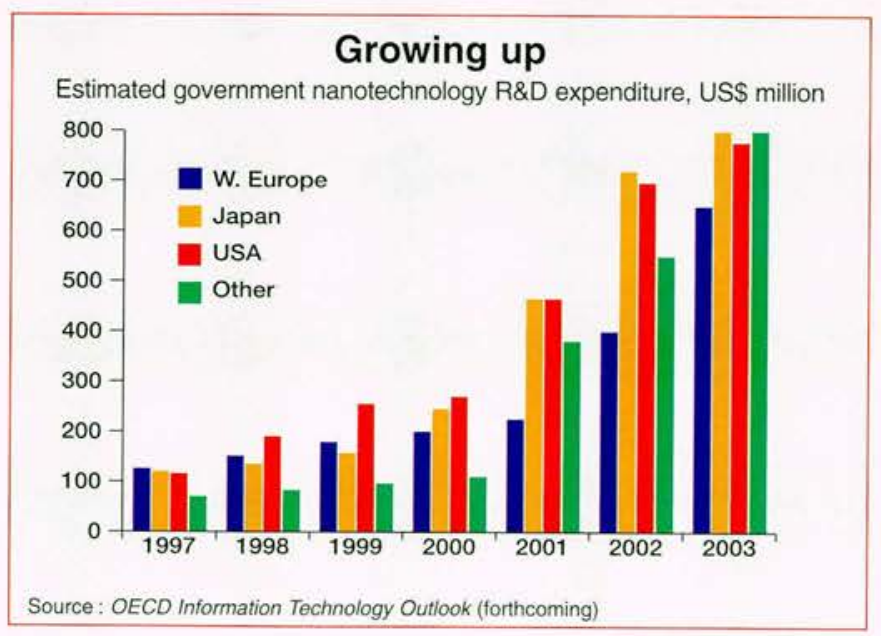

In 2003, the United States passed the 21st Century Nanotechnology Research and Development Act, authorising $\$ 3.7$ billion in federal subsidies for three years beginning in 2005, for projects supported by the National Nanotechnology Initiative (NNI), a federal R\&D programme established in 2001. Government funding for the NNI itself is projected to increase to $\$ 886$ million for 2005 , to constitute roughly $3 \%$ of overall US government R\&D expenditure.

Japanese and western European programmes combine government support with academic and private-sector R\&D activities. In 2003, Japan spent about $\$ 800$ million, while western European government spending (the European Union plus Switzerland) on nanotechnology R\&D totalled about $\$ 650$ million. And the European Commission recently launched a $€ 24$ million project called NanoCMOS to further semiconductor studies.

Similar advances have been made in Korea, with a $\$ 2$ billion Nanotechnology Development Programme launched in 2003, and in Canada, with the establishment of the National Institute for Nanotechnology. Significant nanotechnology programmes also exist in Mexico, Russia, Ukraine, China, Chinese Taipei and Singapore.

The US National Science Foundation projects that worldwide annual industrial production in the nanotechnology sectors will reach over $\$ 1$ trillion by 2015 . 


\section{Indicators}

\begin{tabular}{|c|c|c|c|c|c|c|c|c|}
\hline & & & \multicolumn{2}{|c|}{$\%$ change from: } & & & \multicolumn{2}{|c|}{ level: } \\
\hline & & & $\begin{array}{l}\text { previous } \\
\text { period }\end{array}$ & $\begin{array}{c}\text { previous } \\
\text { year }\end{array}$ & & & $\begin{array}{l}\text { current } \\
\text { period }\end{array}$ & $\begin{array}{l}\text { same period } \\
\text { last year }\end{array}$ \\
\hline \multirow{3}{*}{ Australia } & Gross domestic product & Q4 03 & 1.4 & 4.0 & Current balance & Q4 03 & -8.60 & -5.90 \\
\hline & Leading indicator & Dec. 03 & 0.2 & 1.2 & Unemployment rate & Feb. 04 & 5.90 & 6.10 \\
\hline & Consumer price index & Q4 03 & 0.5 & 2.4 & Interest rate & Feb. 04 & 5.57 & 4.75 \\
\hline \multirow[t]{3}{*}{ Austria } & Gross domestic product & Q4 03 & 0.1 & 0.8 & Current balance & Q3 03 & -1.23 & -0.44 \\
\hline & Leading indicator & Feb. 04 & 0.1 & 7.5 & Unemployment rate & Feb. 04 & 4.40 & 4.30 \\
\hline & Consumer price index & Feb. 04 & 0.4 & 1.4 & Interest rate & & * & * \\
\hline \multirow[t]{3}{*}{ Belgium } & Gross domestic product & Q4 03 & 0.6 & 1.2 & Current balance & Q4 03 & 1.58 & 2.41 \\
\hline & Leading indicator & Feb. 04 & 0.2 & 7.1 & Unemployment rate & Feb. 04 & 8.50 & 7.80 \\
\hline & Consumer price index & Mar. 04 & 0.1 & 1.1 & Interest rate & & * & * \\
\hline \multirow[t]{3}{*}{ Canada } & Gross domestic product & Q4 03 & 0.9 & 1.6 & Current balance & Q4 03 & 5.05 & 3.11 \\
\hline & Leading indicator & Feb. 04 & 0.4 & 5.7 & Unemployment rate & Feb. 04 & 7.40 & 7.50 \\
\hline & Consumer price index & Feb. 04 & 0.2 & 0.7 & Interest rate & Mar. 04 & 2.10 & 3.28 \\
\hline \multirow{3}{*}{ Czech Republic } & Gross domestic product & Q4 03 & 0.7 & 3.2 & Current balance & Q4 03 & -2.05 & -1.04 \\
\hline & Leading indicator & & .. &.. & Unemployment rate & Feb. 04 & 8.20 & 7.50 \\
\hline & Consumer price index & Feb. 04 & 0.1 & 2.2 & Interest rate & Mar. 04 & 2.05 & 2.39 \\
\hline \multirow[t]{3}{*}{ Denmark } & Gross domestic product & Q4 03 & 0.3 & 0.3 & Current balance & Q4 03 & 1.30 & 1.02 \\
\hline & Leading indicator & Feb. 04 & 1.3 & 7.6 & Unemployment rate & Jan. 04 & 6.10 & 5.10 \\
\hline & Consumer price index & Feb. 04 & 0.7 & 0.9 & Interest rate & Mar. 04 & 2.09 & 2.63 \\
\hline \multirow{3}{*}{ Finland } & Gross domestic product & Q4 03 & 0.3 & 1.6 & Current balance & Jan. 04 & 1.09 & 0.78 \\
\hline & Leading indicator & Feb. 04 & 0.2 & 5.3 & Unemployment rate & Feb. 04 & 8.90 & 9.00 \\
\hline & Consumer price index & Feb. 04 & 0.6 & 0.1 & Interest rate & & * & * \\
\hline \multirow[t]{3}{*}{ France } & Gross domestic product & Q4 03 & 0.4 & 0.6 & Current balance & Jan. 04 & -0.52 & 0.58 \\
\hline & Leading indicator & Feb. 04 & 0.4 & 6.8 & Unemployment rate & Feb. 04 & 9.40 & 9.20 \\
\hline & Consumer price index & Feb. 04 & 0.5 & 1.8 & Interest rate & & * & * \\
\hline \multirow[t]{3}{*}{ Germany } & Gross domestic product & Q4 03 & 0.2 & 0.0 & Current balance & Q4 03 & 17.72 & 10.68 \\
\hline & Leading indicator & Feb. 04 & 0.0 & 7.0 & Unemployment rate & Feb. 04 & 9.30 & 9.20 \\
\hline & Consumer price index & Feb. 04 & 0.2 & 0.9 & Interest rate & & * & * \\
\hline \multirow{3}{*}{$\begin{array}{c}\text { Greece } \\
\text { 믈 }\end{array}$} & Gross domestic product & Q4 03 & -0.3 & 5.0 & Current balance & Jan. 04 & -1.74 & -1.40 \\
\hline & Leading indicator & Feb. 04 & -0.7 & 3.9 & Unemployment rate & Sept. 03 & 9.20 & 9.90 \\
\hline & Consumer price index & Feb. 04 & -0.3 & 2.5 & Interest rate & & * & * \\
\hline \multirow[t]{3}{*}{ Hungary } & Gross domestic product & Q4 03 & 3.0 & 3.6 & Current balance & Jan. 04 & -0.42 & -0.08 \\
\hline & Leading indicator & & .. & .. & Unemployment rate & Feb. 04 & 5.90 & 5.80 \\
\hline & Consumer price index & Feb. 04 & 1.2 & 7.1 & Interest rate & Feb. 04 & 12.66 & 5.35 \\
\hline \multirow[t]{3}{*}{ Iceland } & Gross domestic product & Q4 03 & 4.2 & 4.9 & Current balance & Q4 03 & -0.19 & -0.03 \\
\hline & Leading indicator & & .. & .. & Unemployment rate & Feb. 04 & 3.10 & 3.30 \\
\hline & Consumer price index & Mar. 04 & 0.6 & 1.8 & Interest rate & Feb. 04 & 5.29 & 5.80 \\
\hline \multirow[t]{3}{*}{ Ireland } & Gross domestic product & Q4 03 & 6.3 & 2.7 & Current balance & Q4 03 & -1.07 & -0.22 \\
\hline & Leading indicator & Feb. 04 & 0.9 & 18.1 & Unemployment rate & Feb. 04 & 4.50 & 4.50 \\
\hline & Consumer price index & Feb. 04 & 0.8 & 1.7 & Interest rate & & * & * \\
\hline \multirow[t]{3}{*}{ Italy } & Gross domestic product & Q4 03 & 0.0 & 0.1 & Current balance & Oct. 03 & -1.70 & -1.38 \\
\hline & Leading indicator & Feb. 04 & 0.1 & 2.2 & Unemployment rate & Jan. 04 & 8.50 & 8.90 \\
\hline & Consumer price index & Mar. 04 & 0.3 & 2.3 & Interest rate & & * & * \\
\hline Japan & Gross domestic product & Q4 03 & 1.6 & 3.6 & Current balance & Jan. 04 & 15.85 & 8.58 \\
\hline & Leading indicator & Feb. 04 & 0.0 & 2.2 & Unemployment rate & Feb. 04 & 5.00 & 5.20 \\
\hline & Consumer price index & Feb. 04 & 0.0 & 0.0 & Interest rate & Feb. 04 & 0.03 & 0.04 \\
\hline Korea & Gross domestic product & Q4 03 & 2.7 & 4.1 & Current balance & Feb. 04 & 4.49 & 0.39 \\
\hline III & Leading indicator & & .. & .. & Unemployment rate & Feb. 04 & 3.30 & 3.10 \\
\hline $11 \%$ & Consumer price index & Mar. 04 & 1.0 & 3.1 & Interest rate & Feb. 04 & 4.10 & 4.50 \\
\hline
\end{tabular}




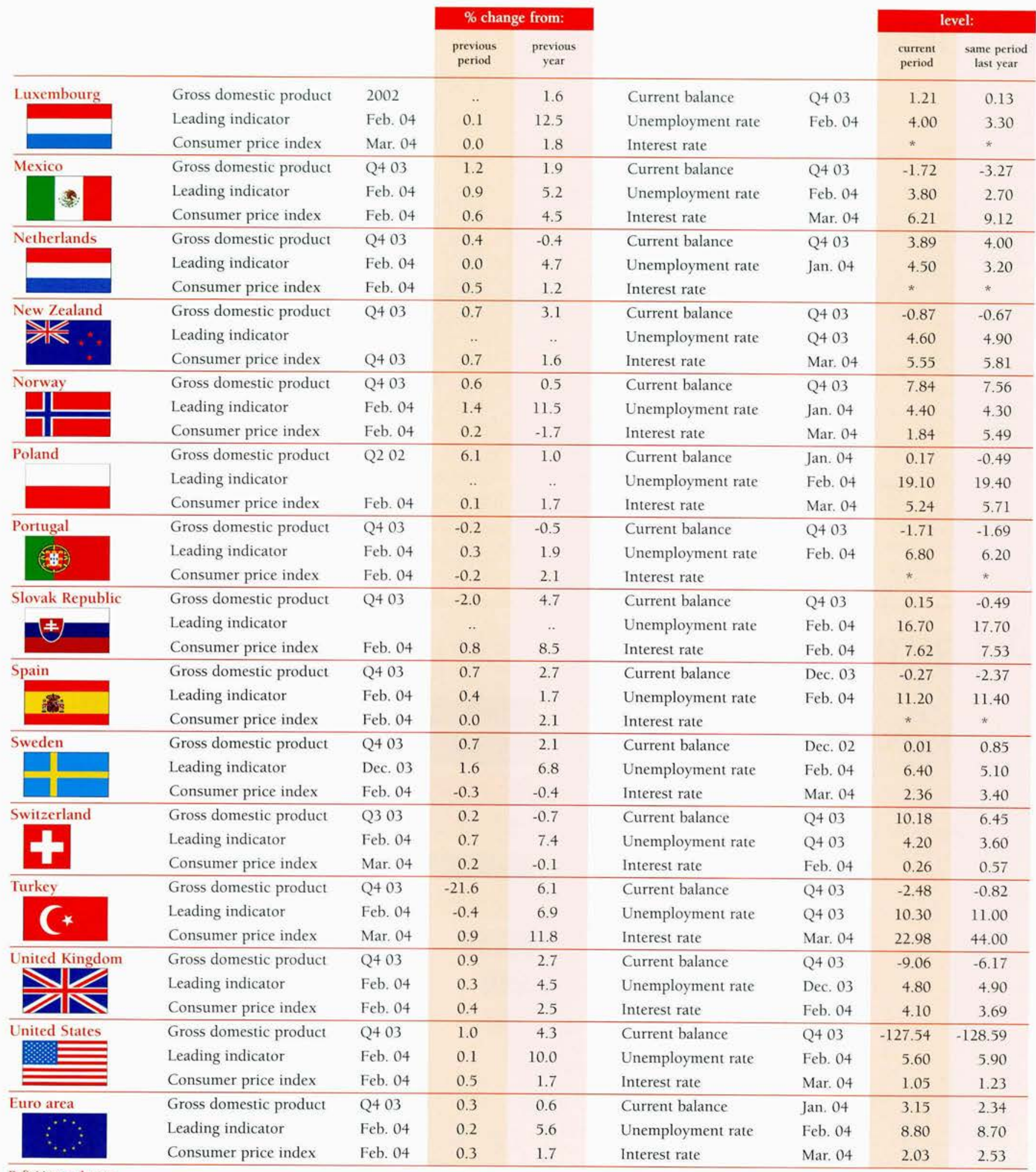

Definitions and notes

Gross Domestic Product: Volume series; seasonally adjusted except for Hungary, lceland, Ireland, Poland. Slovak Republic and Turkey; Leading Indicators: A composite indicator based on other indicators of economic activity (qualitative opinions on production or employment, housing permits, financial or monetary series, etc.), which signals cyclical movements in industrial production from six to nine months in advance; Consumer Price Index: Measures changes in average retail prices of a fixed basket of goods

and services; Current Balance: USS billion; seasonally adjusted except for Greece, Ireland and the Netherlands; Unemployment Rate: \% of civilian labour force-standardised unemployment rate; national definitions for leeland. Korea, Mexico and Turkey; seasonally adjusted apan from Turkey; Interest Rate: Three months, except for Turkey (overnight interbank rate). " refer to Euro zone. , =not available.

Source: Main Economic Indicators, April 2004 


\section{Golden age}

T ow far has the OECD economy travelled in the last two 1 hundred years? According to economic historian, Angus Maddison, GDP per capita worldwide has risen more than eightfold since 1820 , compared with a fivefold increase in population, though the rate of growth has been uneven by time and by country.

From 1870 to 1913 , world capita GDP rose $1.3 \%$ per year compared with $0.5 \%$ in $1820-70$. Two world wars, the collapse of capital flows, migration and trade shattered the old economic order between 1913 and 1950, though by harnessing technological developments - electricity, automobiles, aviation and chemistry, etc. - the United States had become the world leader in terms of productivity and per capita income. The world economy as a whole performed better from 1950 to 2000 than at any time before. Real per capita income rose by $2.1 \%$ a year, compared with $0.9 \%$ from 1820-1950.

The golden age, from 1950 to 1973, saw a degree of convergence between the US and other advanced capitalist countries (western Europe and Japan) coinciding with a new liberal international order. Indeed, Japan, despite just having emerged from a decade of economic stagnation, has had the fastest growth, its per capita

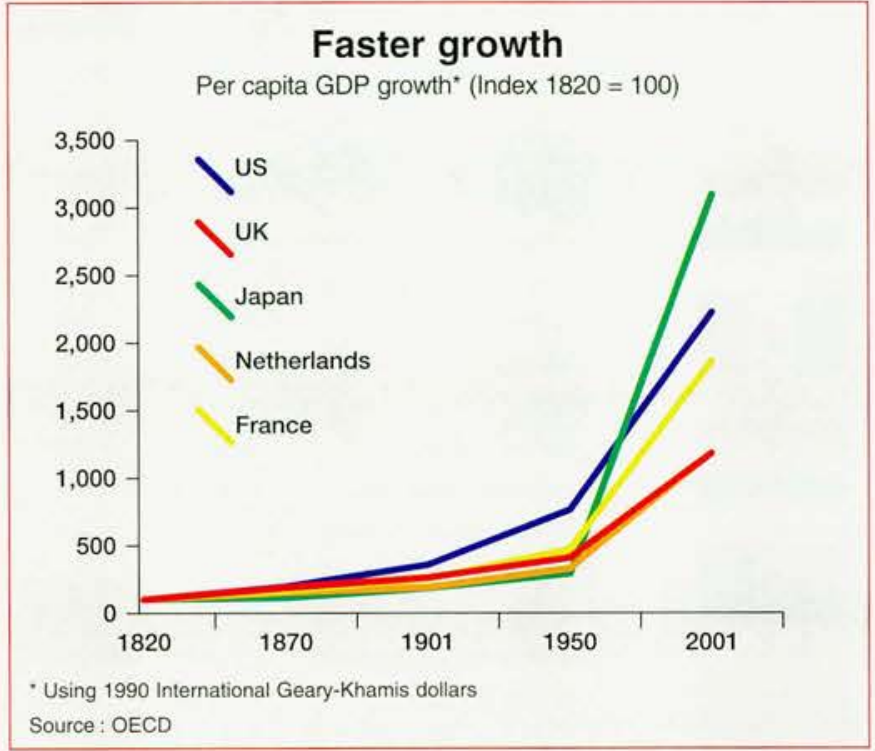

income growth increasing sixfold during the golden age, at $8 \%$ per year compared with $4 \%$ in western Europe.

References

- Maddison A. (2003), The World Economy - A Millennial Perspective, OECD Development Centre.

\section{Ad strength}

nline marketing is thriving in response to the pervasive shift to young and hip internet users from yesterday's couch potatoes. After falling 18\% during 2002 . online advertising experienced an upturn, with revenues expected to have increased $12 \%$ during 2003 to around US $\$ 6.6$ billion, some of the largest brands having increased their online marketing budgets. Half of the top online advertisers in 2002 were Fortune 500 companies, compared with just two in 2000. Agency executives predict that online advertising expenditures will increase rapidly, to as much as $15 \%$ of total ad spending.

In 2002, three of the top 10 advertising agencies in the world were based in the United States (Omnicom, Interpublic and Grey Global), three were based in Japan (Dentsu, Hakuhodo and Asatsu-DK) and there were two in the United Kingdom (WPP and Cordiant) and France (Publicis and Havas). The three largest advertising agencies, Omnicom, Interpublic and WPP Group, each accounted for around 15\% of

\section{Top 10 advertising agencies} 2002 revenue, US\$ millions

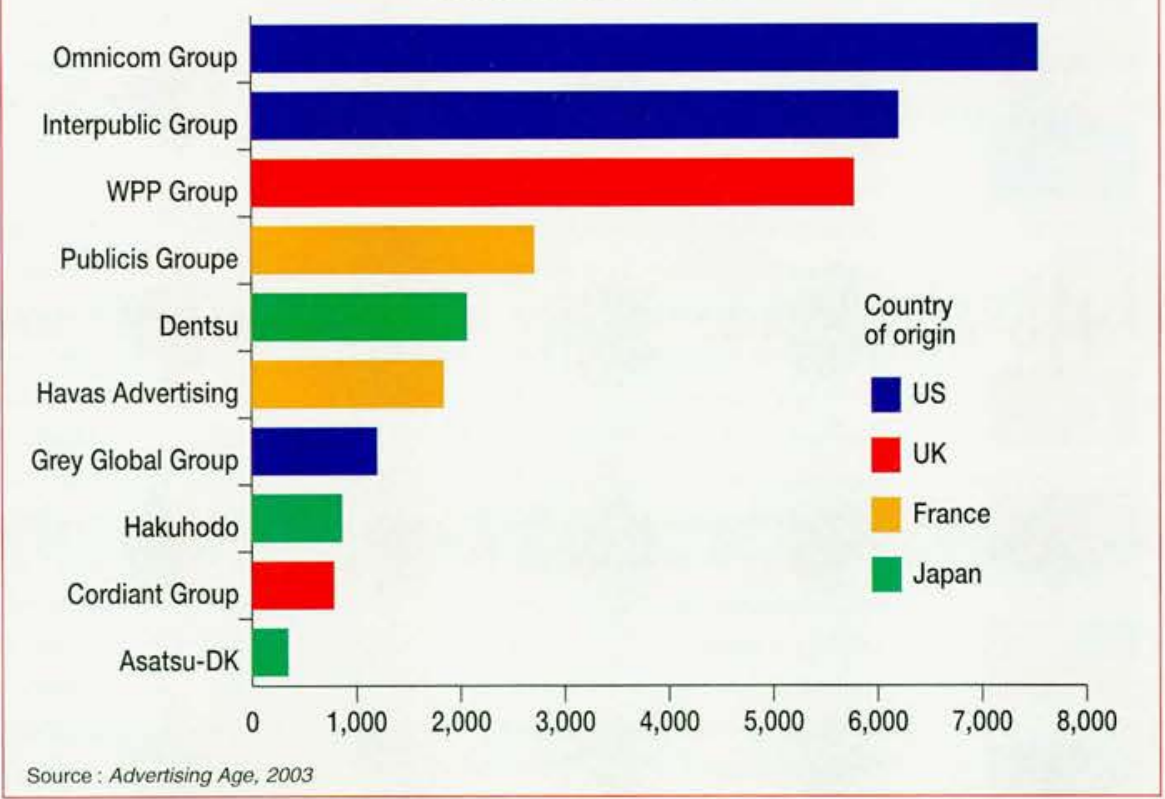

worldwide income from advertising and marketing, making the industry relatively concentrated. These "big three" agencies also appear to be gaining market share, having accounted for a combined $43.7 \%$ of worldwide advertising and marketing services gross income in 2001, compared with $38 \%$ in 2000 . 

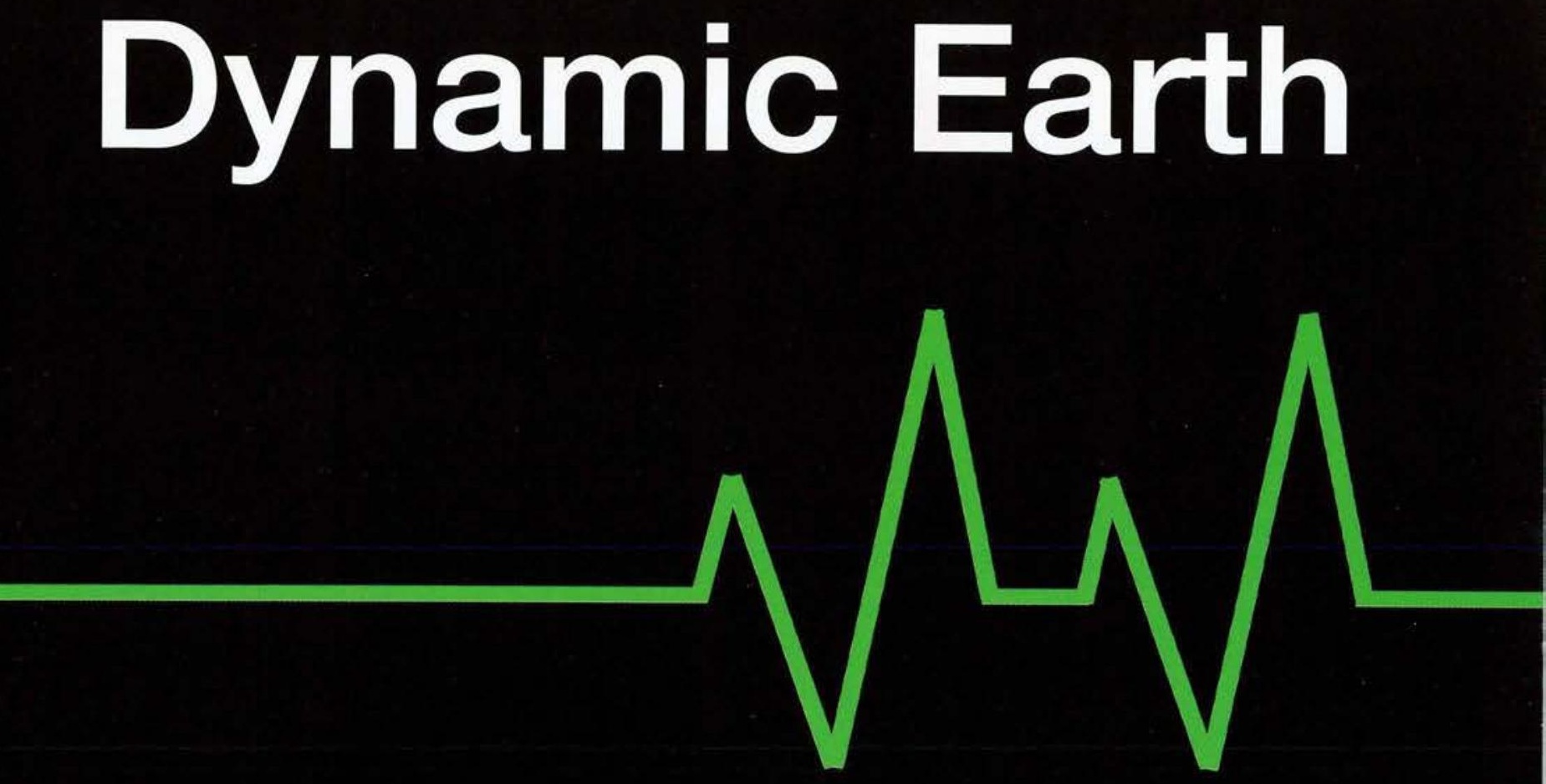

Order OECD publications on environment at www.oecd.org/bookshop
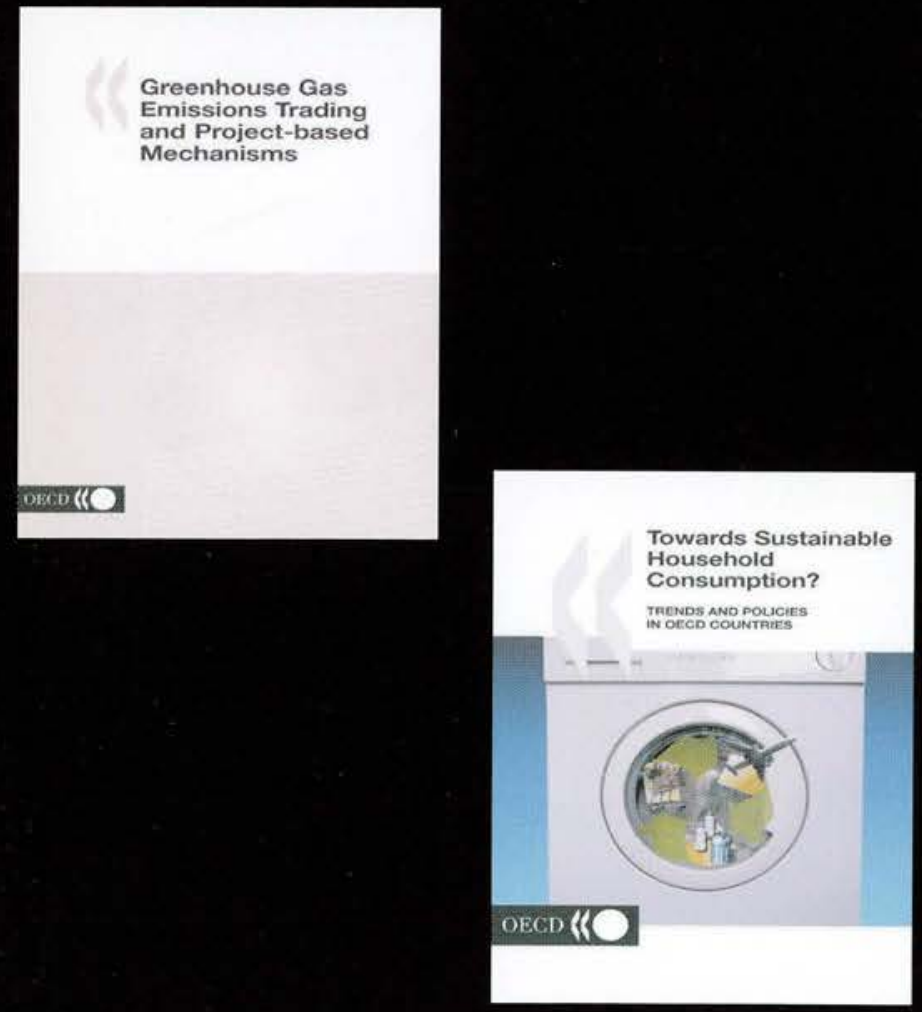
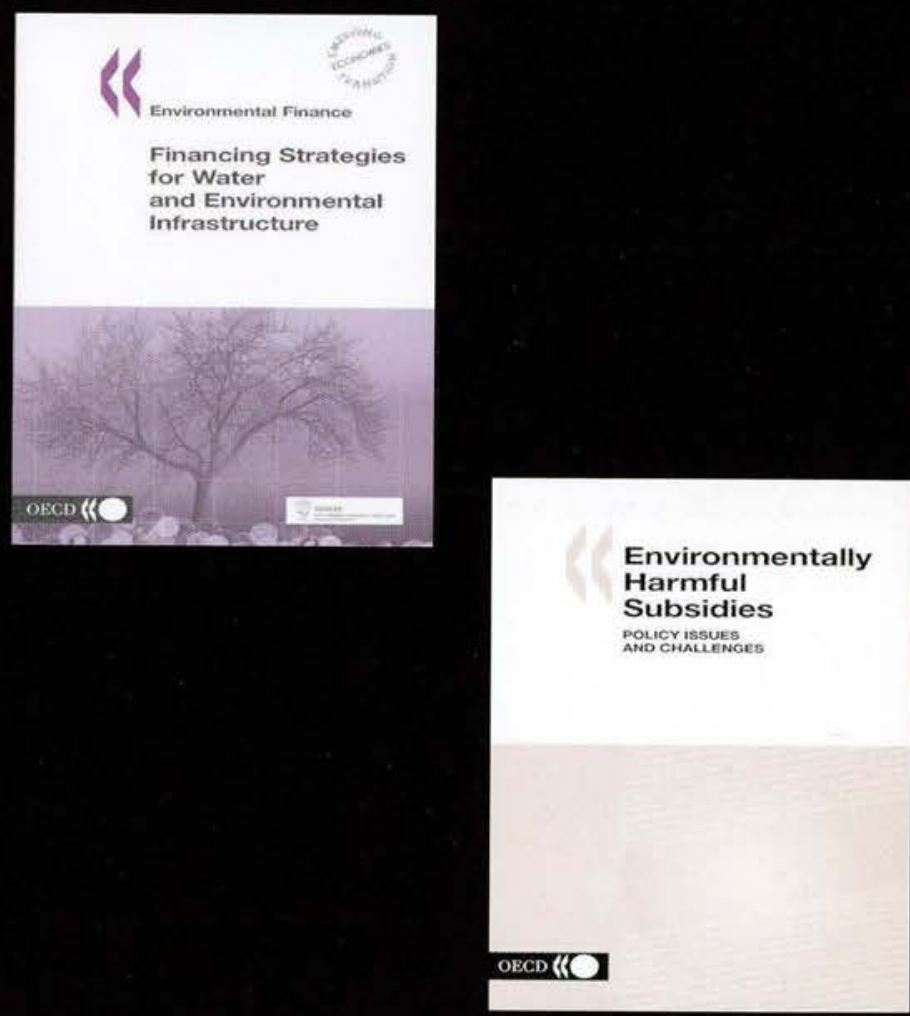

To be the first to know about new OECD publications on environment, sign up for OECDDirect, our free e-mail alert service: www.oecd.org/OECDDirect 


\section{Invest in Africa's farmers for}

\section{long term economic growth}

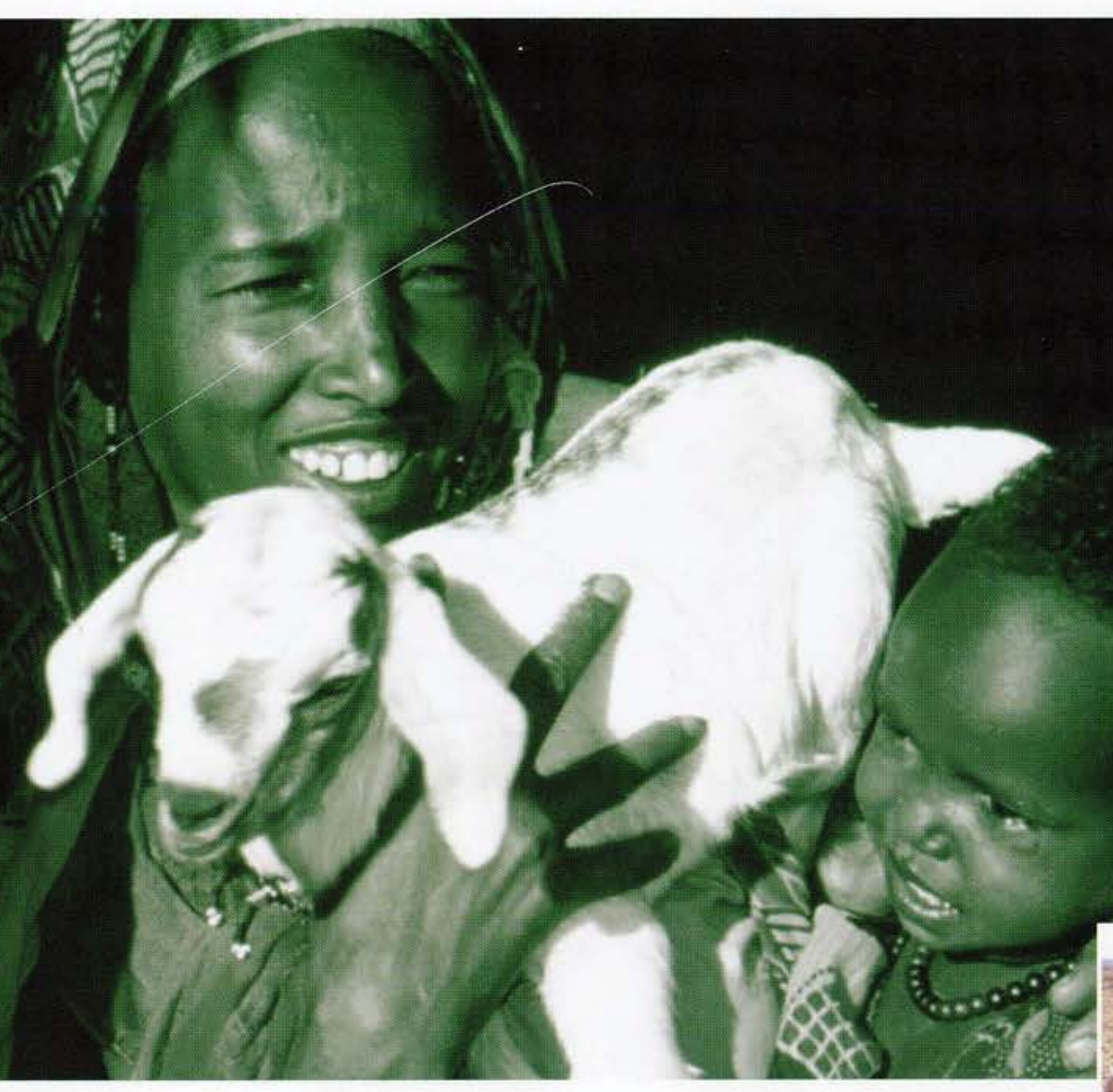

If farming is the basis for rural livelihoods, should it not be the starting point for building a prosperous rural economy and the only sound base for building food security for the poor?

Start from where people are and build on what they have.

"My children have joined school. I have also started other business from the income I earn from my goats" Mrs Kiros Demewoz, project beneficary, Tigray, Ethiopia

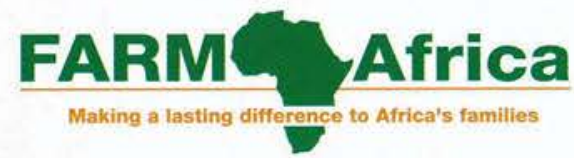

Innovative solutions for Africa's rural problems.
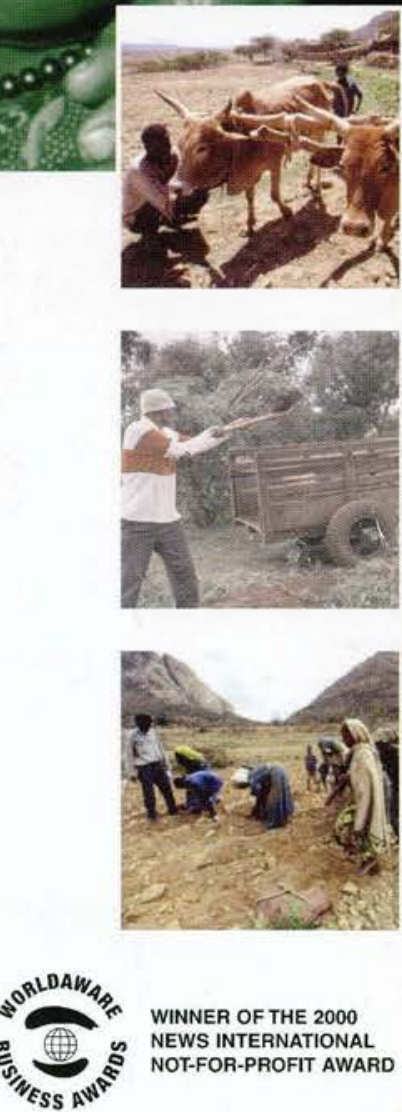